\title{
Enantioselective Total Synthesis of the Potent Antitumor Agent (-)-Mucocin using a Temporary Silicon-Tethered (TST) Ring-Closing Metathesis (RCM) Cross-Coupling Reaction
}

\author{
P. Andrew Evans, * Jian Cui, Santosh J. Gharpure, Alexei Polosukhin and Hai-Ren Zhang \\ Department of Chemistry, Indiana University, Bloomington, IN 47405. \\ Representative Experimental Procedures and Supplemental Data
}

General. The chemical shifts of the ${ }^{1} \mathrm{H}-\mathrm{NMR}$ and ${ }^{13} \mathrm{C}-\mathrm{NMR}$ spectra were all recorded relative to chloroform, benzene or tetramethylsilane. Multiplicities were determined with the aid of an APT sequence, separating methylene and quaternary carbons $=\mathrm{e}($ even$)$, from methyl and methine $=\mathrm{o}$ (odd). GC and HPLC analysis was carried out using an HP 5890 GC Series 2 and HP 1100 HPLC respectively. All compounds were purified using flash chromatography, and gave spectroscopic data consistent with being $\geq 95 \%$ the assigned structure. Analytical t.l.c. was carried out on precoated $0.2 \mathrm{~mm}$ thick Merck $60 \mathrm{~F}_{254}$ silica plates. Flash chromatography was carried out using Merck Silica Gel 60 (230-400 mesh).

(2S)-2-[(1S)-1-(4-Methoxyphenoxy)prop-2-en-1-yl]oxirane. $\quad(1 R)$-1-[(2S)-oxiran-2-yl]prop-2en-1-ol (1.517 g, $15.15 \mathrm{mmol})$, 4-methoxyphenol (2.069 g, $16.67 \mathrm{mmol})$ and triphenylphosphine (4.966 g, $18.94 \mathrm{mmol})$ were dissolved in anhydrous tetrahydrofuran $(76 \mathrm{~mL})$ and the mixture was cooled with stirring to $0{ }^{\circ} \mathrm{C}$ under an atmosphere of nitrogen. Diisopropyl azodicarboxylate (DIAD) $(3.58 \mathrm{~mL}, 18.18 \mathrm{mmol})$ was added dropwise via syringe and the solution was slowly warmed to room temperature and stirred for $c a$. 16 hours (t.l.c. control). The solvent was then removed in vacuo to afford a sticky oily residue, which was purified by flash column chromatography (eluting with 5-15\% ethyl acetate/hexanes) to afford the aryl ether (2.488 g, 80\%) as a colorless liquid: $[\alpha]_{\mathrm{D}}^{22}-12.6\left(\mathrm{c}=1.05, \mathrm{CHCl}_{3}\right)$; IR (neat) $3059(\mathrm{w}), 2997(\mathrm{~m}), 1644(\mathrm{w})$, 1591 (w), 1505 (s), 1466 (m), 1227 (s), 1037 (s), 994 (m), 936 (m), 826 (s) cm ${ }^{-1} ;{ }^{1}$ H NMR (400 $\left.\mathrm{MHz}, \mathrm{CDCl}_{3}\right) \delta$ 6.93-6.88 (m, 2H), 6.83-6.78 (m, 2H), 5.90 (ddd, $\left.J=17.2,10.6,6.0 \mathrm{~Hz}, 1 \mathrm{H}\right), 5.40$ $(\mathrm{dt}, J=17.4,1.2 \mathrm{~Hz}, 1 \mathrm{H}), 5.32(\mathrm{dt}, J=10.6,1.1 \mathrm{~Hz}, 1 \mathrm{H}), 4.34(\mathrm{ddt}, J=5.8,5.8,1.2 \mathrm{~Hz}, 1 \mathrm{H}), 3.76$ 
(s, 3H), 3.24 (ddd, $J=7.2,4.0,2.8 \mathrm{~Hz}, 1 \mathrm{H}$ ), 2.87 (dd, $J=4.5,4.5 \mathrm{~Hz}, 1 \mathrm{H}$ ), 2.73 (dd, $J=4.8,2.7$ $\mathrm{Hz}, 1 \mathrm{H}$ ); ${ }^{13} \mathrm{C} \mathrm{NMR}\left(100 \mathrm{MHz}, \mathrm{CDCl}_{3}\right.$ ) $\delta 154.28$ (e), 151.86 (e), 133.39 (o), 118.63 (e), 117.53 (o), 114.43 (o), 80.98 (o), 55.58 (o), 53.59 (o), 44.23(e); HRMS (EI, $\mathrm{M}^{+}$) calcd for $\mathrm{C}_{12} \mathrm{H}_{14} \mathrm{O}_{3}$ 206.0943, found 206.0941.

tert-Butyldimethyl-[(1-vinylprop-2-en-1-yl)oxy]silane. Divinylcarbinol (8.41 g, 100 mmol), triethylamine $(21 \mathrm{~mL}, 150 \mathrm{mmol})$ and DMAP $(1.20 \mathrm{~g}, 10 \mathrm{mmol})$ were dissolved in dichloromethane $(500 \mathrm{~mL})$ and cooled with stirring to $0{ }^{\circ} \mathrm{C}$ under an atmosphere of nitrogen. tertButyldimethylsilyl chloride (18 g, $120 \mathrm{mmol}$ ) was added, and the reaction mixture allowed to warm to room temperature and stirred for $c a .16$ hours (t.l.c. control). The reaction mixture was quenched with water and partitioned between diethyl ether and water. The combined organic phases were dried $\left(\mathrm{Na}_{2} \mathrm{SO}_{4}\right)$, filtered and concentrated in vacuo to afford a crude oil. Purification by flash chromatography (eluting with $5 \%$ diethyl ether/pentane) furnished the tertbutyldimethylsilyl ether (19.44 g, 98\%) as a colorless oil: IR (neat) 3083 (w), 3018 (w), 2958 (s), 2931 (s), 2888 (m), 2859 (s), 1638 (w), 1473 (m), 1464 (m), 1253 (s), 1126 (s), 1032 (s), 991 (m), 922 (s), 854 (s), 776 (s) $\mathrm{cm}^{-1} ;{ }^{1} \mathrm{H}$ NMR (400 MHz, $\mathrm{CDCl}_{3}$ ) $\delta 5.80$ (ddd, $J=17.1,10.4,5.2 \mathrm{~Hz}$, 2H), $5.21(\mathrm{dt}, J=17.1,1.6 \mathrm{~Hz}, 2 \mathrm{H}), 5.05(\mathrm{dt}, J=10.4,1.5 \mathrm{~Hz}, 2 \mathrm{H}), 4.61-4.58(\mathrm{~m}, 1 \mathrm{H}), 0.90(\mathrm{~s}$, 9H), 0.06 (s, 6H); ${ }^{13} \mathrm{C}$ NMR (100 MHz, $\mathrm{CDCl}_{3}$ ) $\delta 140.30$ (o), 113.83 (e), 74.78 (o), 25.99 (o), 18.54 (e), -4.62 (o); HRMS (FAB, M+Na ${ }^{+}$) calcd for $\mathrm{C}_{11} \mathrm{H}_{22} \mathrm{NaOSi} 221.1338$, found 221.1334.

(3Z,7S,8S)-3,7-Di[tert-butyl(dimethyl)silyl]oxy-8-(4-methoxyphenoxy)deca-1,3,9-triene (7). tert-Butyldimethyl-[(1-vinylprop-2-en-1-yl)oxy]silane (1.488 g, $7.5 \mathrm{mmol})$ was dissolved in anhydrous tetrahydrofuran $(15 \mathrm{~mL})$ and cooled with stirring to $-78{ }^{\circ} \mathrm{C}$ under an atmosphere of argon. sec-Butyllithium (5 mL, $7.0 \mathrm{mmol}, 1.4 \mathrm{M}$ solution in cyclohexanes) was added dropwise to the diene, and the reaction mixture stirred for $c a .40$ minutes. (2S)-2-[(1S)-1-(4methoxyphenoxy)prop-2-en-1-yl]oxirane $(1.031 \mathrm{~g}, 5 \mathrm{mmol})$ in anhydrous tetrahydrofuran $(2 \mathrm{~mL})$ was added slowly to the carbanion solution, and stirred for $c a .4$ hours (t.l.c. control). 2,6-Lutidine $(1.8 \mathrm{~mL}, 15 \mathrm{mmol})$ was then added dropwise and the reaction mixture allowed to warm up to $0{ }^{\circ} \mathrm{C}$. tert-Butyldimethylsilyl triflate $(2.3 \mathrm{~mL}, 10 \mathrm{mmol})$ was added, and the reaction mixture stirred for ca. 2 hours at $0{ }^{\circ} \mathrm{C}$ (t.l.c. control). The reaction was quenched with saturated aqueous sodium bicarbonate solution and partitioned between diethyl ether and saturated aqueous sodium 
bicarbonate. The combined organic phases were washed with brine, dried $\left(\mathrm{Na}_{2} \mathrm{SO}_{4}\right)$ and concentrated in vacuo to afford a crude oil. Purification by flash chromatography (eluting with

$10-20 \%$ benzene/hexanes) furnished the dienol $7(2.491 \mathrm{~g}, 96 \%)$ as a colorless oil: $[\alpha]_{\mathrm{D}}{ }^{25}-21.1$ (c = 1.00, $\mathrm{CHCl}_{3}$ ); IR (neat) 2955 (s), 2930 (s), 2895 (m), 2858 (s), 1645 (w), 1605 (m), 1507 (vs), 1255 (s), 1227 (s), 1047 (s), 838 (s), 778 (s) cm ${ }^{-1}$; ${ }^{1} \mathrm{H} \mathrm{NMR} \mathrm{(400} \mathrm{MHz,} \mathrm{CDCl}{ }_{3}$ ) 6.82-6.76 (m, 4H), 6.13 (dd, $J=17.1,10.7 \mathrm{~Hz}, 1 \mathrm{H}), 5.85$ (ddd, $J=17.2,10.9,6.0 \mathrm{~Hz}, 1 \mathrm{H}), 5.29-5.22$ (m, 3H), $4.94(\mathrm{~d}, J=10.7 \mathrm{~Hz}, 1 \mathrm{H}), 4.76(\mathrm{t}, J=7.0 \mathrm{~Hz}, 1 \mathrm{H}), 4.46$ (t, $J=5.6 \mathrm{~Hz}, 1 \mathrm{H}), 3.84$ (ddd, $J=8.4,5.4$, $3.4 \mathrm{~Hz}, 1 \mathrm{H}), 3.74$ (s, 3H), 2.29-2.09 (m, 2H), 1.72-1.64 (m, 1H), 1.52-1.43 (m, 1H), 0.98 (s, 9H), 0.88 (s, $9 \mathrm{H}), 0.10$ (s, 6H), 0.08 (s, 3H), 0.05 (s, 3H); $\left.{ }^{13} \mathrm{C} \mathrm{NMR} \mathrm{(100} \mathrm{MHz,} \mathrm{CDCl}_{3}\right) \delta 153.97$ (e), 152.34 (e), 148.51 (e), 135.82 (o), 134.35 (o), 118.16 (e), 117.31 (o), 115.99 (o), 114.57 (o), 112.16 (e), 82.47 (o), 73.92 (o), 55.80 (o), 32.59 (e), 26.16 (o), 26.11 (o), 22.51 (e), 18.57 (e), 18.31 (e), -3.44 (o), -3.98 (o), -4.45 (o); HRMS (EI, $\mathrm{M}^{+}$) calcd for $\mathrm{C}_{29} \mathrm{H}_{50} \mathrm{O}_{4} \mathrm{Si}_{2}$ 518.3248, found 518.3267 .

(4R,7S,8S)-7-\{[tert-Butyl(dimethyl)silyl] oxy\}-4-hydroxy-8-(4-methoxyphenoxy)deca-1,9-dien3-one (8). $\mathrm{K}_{3} \mathrm{Fe}(\mathrm{CN})_{6}(4.939 \mathrm{~g}, 15.0 \mathrm{mmol}), \mathrm{K}_{2} \mathrm{CO}_{3}(2.073 \mathrm{~g}, 15.0 \mathrm{mmol}), \mathrm{K}_{2} \mathrm{OsO}_{4} \cdot 2 \mathrm{H}_{2} \mathrm{O}(36.8$ $\mathrm{mg}, 0.1 \mathrm{mmol}$ ) and (DHQD) ${ }_{2}$ PHAL (194.8 mg, $\left.0.25 \mathrm{mmol}\right)$ were dissolved in tert-butanol/water $(50 \mathrm{~mL}, 1: 1)$. The reaction mixture was stirred at room temperature until both phases were clear, then $\mathrm{MeSO}_{2} \mathrm{NH}_{2}$ (475.6 mg, $5 \mathrm{mmol}$ ) was added and the mixture was stirred for $\mathrm{ca}$. 5 minutes before cooling to $0{ }^{\circ} \mathrm{C}$. The reaction mixture was then transferred to the pre-cooled $\left(0{ }^{\circ} \mathrm{C}\right)$ triene 7 $(2.572 \mathrm{~g}, 5 \mathrm{mmol})$, and the heterogeneous slurry stirred at $0{ }^{\circ} \mathrm{C}$ for $c a .15$ minutes. The reaction was quenched at $0{ }^{\circ} \mathrm{C}$ by the addition of $\mathrm{Na}_{2} \mathrm{~S}_{2} \mathrm{O}_{3}(7.5 \mathrm{~g})$ and the reaction mixture allowed to warm up to room temperature where it was stirred for an additional hour. The reaction mixture was then partitioned between ethyl acetate and water. The combined organic phases were dried $\left(\mathrm{Na}_{2} \mathrm{SO}_{4}\right)$, filtered and concentrated in vaсuo to afford a crude oil. Purification by flash chromatography (eluting with 10-20\% ethyl acetate/hexanes) furnished the enone $8(1.051 \mathrm{~g})$ as a colorless oil. The triene 7 (0.966 g, 38\%) was recovered and resubmitted to the reaction conditions outlined above. Overall yield of the enone 8 after 3 cycles $(1.475 \mathrm{~g}, 70 \%):[\alpha]_{\mathrm{D}}{ }^{24}-61.8\left(\mathrm{c}=1.04, \mathrm{CHCl}_{3}\right)$; IR (neat) 3482 (s), 2954 (s), 2930 (s), 2895 (m), 2857 (s), 1698 (m), 1616 (m), 1506 (vs), 1228 (vs), 1181 (m), 1107 (s), 1085 (s), 1040 (s), 991 (m), 836 (s), 777 (s) cm ${ }^{-1}$; ${ }^{1} \mathrm{H}$ NMR (400 MHz, $\left.\mathrm{CDCl}_{3}\right) \delta 6.81-6.75(\mathrm{~m}, 4 \mathrm{H}), 6.50(\mathrm{dd}, J=17.4,10.1 \mathrm{~Hz}, 1 \mathrm{H}), 6.39(\mathrm{dd}, J=17.4,1.5 \mathrm{~Hz}, 1 \mathrm{H})$, 
$5.87(\mathrm{dd}, J=10.4,1.5 \mathrm{~Hz}, 1 \mathrm{H}), 5.81(\mathrm{ddd}, J=17.1,10.8,6.1 \mathrm{~Hz}, 1 \mathrm{H}), 5.27(\mathrm{~d}, J=13.2 \mathrm{~Hz}, 1 \mathrm{H})$, $5.24(\mathrm{~d}, J=6.4 \mathrm{~Hz}, 1 \mathrm{H}), 4.45(\mathrm{t}, J=6.0 \mathrm{~Hz}, 1 \mathrm{H}), 4.42-4.38(\mathrm{~m}, 1 \mathrm{H}), 3.85-3.81(\mathrm{~m}, 1 \mathrm{H}), 3.72(\mathrm{~s}$, $3 \mathrm{H}), 3.58(\mathrm{~d}, J=5.5 \mathrm{~Hz}, 1 \mathrm{H}), 2.04\left(\mathrm{ABM}_{2} \mathrm{X}, J_{A B}=12.5, J_{A M}=3.5 J_{A X}=3.5 \mathrm{~Hz}, 1 \mathrm{H}\right), 1.78$ $\left(\mathrm{ABM}_{2} \mathrm{X}, J_{A B}=12.6, J_{B M}=3.9 J_{B X}=3.9 \mathrm{~Hz}, 1 \mathrm{H}\right), 1.62-1.47(\mathrm{~m}, 2 \mathrm{H}), 0.86(\mathrm{~s}, 9 \mathrm{H}), 0.05(\mathrm{~s}, 3 \mathrm{H})$, 0.03 (s, 3H); ${ }^{13} \mathrm{C} \mathrm{NMR} \mathrm{(100} \mathrm{MHz,} \mathrm{CDCl}_{3}$ ) $\delta 201.05$ (e), 153.92 (e), 152.08 (e), 134.00 (o), 131.30 (o), 130.58 (e), 118.53 (e), 117.23 (o), 114.47 (o), 82.53 (o), 75.43 (o), 73.69 (o), 55.65 (o), 30.25 (e), 28.54 (e), 25.97 (o), 18.24 (e), -4.07 (o), -4.63 (o); HRMS (EI, M ) calcd for $\mathrm{C}_{23} \mathrm{H}_{36} \mathrm{O}_{5} \mathrm{Si}$ 420.2332, found 420.2342.

\section{(3S,4S,7R)-4-\{[tert-Butyl(dimethyl)silyl] oxy\}-7-hydroxy-3-(4-methoxyphenoxy)-octadec-1-en-}

8-one (9). Octylmagnesium bromide $\left(18.0 \mathrm{~mL}, 36.0 \mathrm{mmol}, 2.0 \mathrm{M}\right.$ solution in $\left.\mathrm{Et}_{2} \mathrm{O}\right)$ was added to a suspension of copper cyanide $(3.224 \mathrm{~g}, 36.0 \mathrm{mmol})$ in anhydrous diethyl ether $(100 \mathrm{~mL})$ at -78 ${ }^{\circ} \mathrm{C}$ under an atmosphere of argon. The reaction mixture was stirred for $c a .30$ minutes, then the enone $8(4.677 \mathrm{~g}, 11.0 \mathrm{mmol})$ in anhydrous diethyl ether $(10 \mathrm{~mL})$ was added and the resulting mixture stirred for an additional ca. 4 hours (t.l.c. control). The reaction mixture was quenched with saturated aqueous ammonium chloride solution and partitioned between diethyl ether and saturated aqueous ammonium chloride. The combined organic phases were washed with brine, dried $\left(\mathrm{Na}_{2} \mathrm{SO}_{4}\right)$ and concentrated in vacuo to afford a crude oil. Purification by flash chromatography (eluting with 10\% ethyl acetate/hexanes) furnished the ketone 9 (3.865 g, 65\%) as a colorless oil: $[\alpha]_{\mathrm{D}}{ }^{24}-49.9\left(\mathrm{c}=1.02, \mathrm{CHCl}_{3}\right)$; IR (neat) $3483(\mathrm{br}, \mathrm{w}), 2954$ (s), 2928 (s), 2856 (s), 1712 (m), 1507 (vs), 1228 (s), 1106 (m), 1086 (m), 1041 (m), 1005 (m), 835 (s), 776 (m) cm ; ${ }^{1} \mathrm{H}$ NMR (400 MHz, $\mathrm{CDCl}_{3}$ ) $\delta$ 6.81-6.75 (m, 4H), 5.83 (ddd, $\left.J=17.2,10.9,6.0 \mathrm{~Hz}, 1 \mathrm{H}\right)$, 5.29-5.23 $(\mathrm{m}, 2 \mathrm{H}), 4.46(\mathrm{t}, J=5.8 \mathrm{~Hz}, 1 \mathrm{H}), 4.13(\mathrm{dt}, J=7.7,3.9 \mathrm{~Hz}, 1 \mathrm{H}), 3.87-3.82(\mathrm{~m}, 1 \mathrm{H}), 3.72(\mathrm{~s}, 3 \mathrm{H})$, $3.57(\mathrm{~d}, J=4.6 \mathrm{~Hz}, 1 \mathrm{H}), 2.47\left(\mathrm{dt}, \mathrm{A}\right.$ of $\left.\mathrm{ABX}_{2}, J_{A B}=16.3, J_{A X}=7.9 \mathrm{~Hz}, 1 \mathrm{H}\right), 2.39$ (dt, B of $\mathrm{ABX}_{2}$, $\left.J_{A B}=16.3, J_{B X}=7.9 \mathrm{~Hz}, 1 \mathrm{H}\right), 2.05(\mathrm{tt}, J=12.2,3.6 \mathrm{~Hz}, 1 \mathrm{H}), 1.75(\mathrm{tt}, J=12.6,4.0 \mathrm{~Hz}, 1 \mathrm{H}), 1.61-$ $1.45(\mathrm{~m}, 4 \mathrm{H}), 1.30-1.20(\mathrm{~m}, 14 \mathrm{H}), 0.88(\mathrm{~s}, 9 \mathrm{H}), 0.86$ (t, J=7.3 Hz, 3H), 0.08 (s, 3H), 0.05 (s, 3H); ${ }^{13} \mathrm{C}$ NMR (100 MHz, $\mathrm{CDCl}_{3}$ ) $\delta 212.40$ (e), 153.96 (e), 152.07 (e), 134.04 (o), 118.51 (e), 117.19 (o), 114.49 (o), 82.46 (o), 76.66 (o), 73.80 (o), 55.66 (o), 37.98 (e), 31.97 (e), 30.00 (e), 29.64 (e), 29.54 (e), 29.45 (e), 29.39 (e), 29.36 (e), 28.64 (e), 26.01 (o), 23.72 (e), 22.77 (e), 18.27 (e), 14.21 (o), -4.04 (o), -4.58 (o); HRMS (EI, M+H') calcd for $\mathrm{C}_{31} \mathrm{H}_{55} \mathrm{O}_{5} \mathrm{Si} 535.3819$, found 535.3826. 
(2S,3R,6S)-2-Decyl-6-[(IS)-1-(4-methoxyphenoxy)prop-2-en-1-yl]tetrahydro-2H-pyran-3-ol

(10). The ketone $9(2.717 \mathrm{~g}, 5.1 \mathrm{mmol})$ was dissolved in acetonitrile $(51 \mathrm{~mL})$ and cooled with stirring to $0{ }^{\circ} \mathrm{C}$ under an atmosphere of nitrogen. Bismuth tribromide $(2.737 \mathrm{~g}, 6.1 \mathrm{mmol})$, prepared as a solution in acetonitrile $(5 \mathrm{~mL})$, was added in one portion via syringe followed by tert-butyldimethylsilane $(2.5 \mathrm{~mL}, 15.3 \mathrm{mmol})$. The reaction mixture was stirred for $c a .10$ minutes (t.l.c. control), and then 2,6-lutidine ( $3.6 \mathrm{~mL}, 30.6 \mathrm{mmol})$ was added dropwise via syringe. The reaction was stirred for an additional 30 minutes at $0{ }^{\circ} \mathrm{C}$, then tert-butyldimethylsilyl triflate $(2.3$ $\mathrm{mL}, 10.2 \mathrm{mmol}$ ) was added dropwise and the mixture stirred for $c a .1$ hour (t.l.c. control). The reaction mixture was then quenched with saturated aqueous sodium bicarbonate and partitioned between diethyl ether and saturated aqueous sodium bicarbonate. The combined organic phases were washed with brine, dried $\left(\mathrm{Na}_{2} \mathrm{SO}_{4}\right)$, filtered and concentrated in vacuo to afford a crude oil. Purification by flash chromatography (eluting with 5\% ethyl acetate/hexanes) furnished the tetrahydropyran $\mathbf{1 0}(2.452 \mathrm{~g}, 93 \%)$ as a colorless oil: $[\alpha]_{\mathrm{D}}{ }^{26}-65.8\left(\mathrm{c}=1.07, \mathrm{CHCl}_{3}\right)$; IR (neat) 2927 (vs), 2856 (s), 1507 (vs), 1592 (w), 1250 (m), 1229 (vs), 1106 (s), 837 (s), 775 (m); ${ }^{1} \mathrm{H}$ NMR (400 MHz, $\left.\mathrm{CDCl}_{3}\right) \delta$ 6.89-6.85 (m, 2H), 6.79-6.75 (m, 2H), 5.90 (ddd, $J=17.2,10.9,6.0$ $\mathrm{Hz}, 1 \mathrm{H}), 5.28(\mathrm{~d}, J=17.4 \mathrm{~Hz}, 1 \mathrm{H}), 5.23(\mathrm{~d}, J=11.0 \mathrm{~Hz}, 1 \mathrm{H}), 4.43(\mathrm{t}, J=5.6 \mathrm{~Hz}, 1 \mathrm{H}), 3.74(\mathrm{~s}$, $3 \mathrm{H}), 3.49$ (ddd, $J=11.0,5.4,2.0 \mathrm{~Hz}, 1 \mathrm{H}), 3.26(\mathrm{dt}, J=9.4,4.2 \mathrm{~Hz}, 1 \mathrm{H}), 3.04(\mathrm{dt}, J=8.6,2.6 \mathrm{~Hz}$, $1 \mathrm{H}), 2.02-1.97(\mathrm{~m}, 1 \mathrm{H}), 1.80-1.68(\mathrm{~m}, 2 \mathrm{H}), 1.57-1.40(\mathrm{~m}, 3 \mathrm{H}), 1.30-1.24(\mathrm{~m}, 16 \mathrm{H}), 0.87(\mathrm{~s}, 9 \mathrm{H})$, $0.87(\mathrm{t}, J=6.0 \mathrm{~Hz}, 3 \mathrm{H}), 0.04(\mathrm{~s}, 6 \mathrm{H}) ;{ }^{13} \mathrm{C} \mathrm{NMR}\left(100 \mathrm{MHz}, \mathrm{CDCl}_{3}\right) \delta 154.18(\mathrm{e}), 153.08(\mathrm{e})$, 135.04 (o), 117.91 (o), 117.61 (e), 114.47 (o), 82.80 (o), 82.76 (o), 78.97 (o), 71.46 (o), 55.76 (o), 33.41 (e), 32.12 (e), 29.84 (e), 29.81 (e), 29.77 (e), 29.52 (e), 26.54 (e), 25.96 (o), 25.43 (e), 22.85 (e), 18.13 (e), 14.30 (o), -3.87 (o), -4.56 (o); HRMS (EI, M+) calcd for $\mathrm{C}_{31} \mathrm{H}_{54} \mathrm{O}_{4} \mathrm{Si}$ 518.3791, found 518.3792 .

\section{(1S)-1-((2S,5R,6S)-5-\{[tert-Butyl(dimethyl)silyl]oxy\}-6-decyltetrahydro-2H-pyran-2-yl)prop-}

2-en-1-ol (2). Ceric ammonium nitrate $(2.68 \mathrm{~g}, 4.89 \mathrm{mmol})$ was added in a single portion to the tetrahydropyran $10(847.3 \mathrm{mg}, 1.63 \mathrm{mmol})$ in acetonitrile/water $(25 \mathrm{~mL}, 4: 1)$ at $-5{ }^{\circ} \mathrm{C}$ under an atmosphere of argon. The reaction mixture was stirred for an additional $c a .20$ minutes (t.l.c. control) and partitioned between ethyl acetate and water. The combined organic phases were dried $\left(\mathrm{Mg}_{2} \mathrm{SO}_{4}\right)$, filtered and concentrated in vacuo to afford a crude oil. Purification by flash chromatography (eluting with 5\% ethyl acetate/hexanes) furnished the alcohol 2 (613.3 $\mathrm{mg}, 91 \%)$ 
as a colorless oil: $[\alpha]_{\mathrm{D}}^{25}-40.1\left(\mathrm{c}=1.00, \mathrm{CHCl}_{3}\right)$; IR (neat) $3575(\mathrm{w}), 3471$ (br, w), 2927 (vs), 2856 (s), 1646 (w), 1463 (m), 1251 (m), 1095 (s), 837 (s), 775 (s); ${ }^{1} \mathrm{H}$ NMR (400 MHz, CDCl ${ }_{3}$ ) $5.78(\mathrm{ddd}, J=17.1,10.4,6.7 \mathrm{~Hz}, 1 \mathrm{H}), 5.33$ (dt, $J=17.2,1.4 \mathrm{~Hz}, 1 \mathrm{H}), 5.19$ (dt, $J=10.7,1.3 \mathrm{~Hz}$, $1 \mathrm{H}), 3.87(\mathrm{t}, J=7.0 \mathrm{~Hz}, 1 \mathrm{H}), 3.23(\mathrm{dt}, J=9.5,4.5 \mathrm{~Hz}, 1 \mathrm{H}), 3.15-3.10(\mathrm{~m}, 1 \mathrm{H}), 3.05$ (dt, $J=8.6$, $2.3 \mathrm{~Hz}, 1 \mathrm{H}), 2.80$ (br s, 1H), 1.99-1.94 (m, 1H), 1.82-1.77 (m, 1H), 1.66-1.62 (m, 1H), 1.47-1.19 $(\mathrm{m}, 19 \mathrm{H}), 0.86(\mathrm{t}, J=6.9 \mathrm{~Hz}, 3 \mathrm{H}), 0.86(\mathrm{~s}, 9 \mathrm{H}), 0.04(\mathrm{~s}, 3 \mathrm{H}), 0.03(\mathrm{~s}, 3 \mathrm{H}) ;{ }^{13} \mathrm{C} \mathrm{NMR}(100 \mathrm{MHz}$, $\mathrm{CDCl}_{3}$ ) $\delta 136.59$ (o), 117.67 (e), 82.45 (o), 79.95 (o), 76.15 (o), 71.39 (o), 33.15 (e), 32.14 (e), 32.07 (e), 29.79 (e), 29.72 (e), 29.49 (e), 27.05 (e), 25.93 (o), 25.56 (e), 22.84 (e), 18.11 (e), 14.27 (o), -3.87 (o), -4.59 (o); HRMS (FAB, M+Na ${ }^{+}$) calcd for $\mathrm{C}_{24} \mathrm{H}_{48} \mathrm{NaO}_{3} \mathrm{Si} 435.3270$, found 435.3256.

\{(2S,5S)-5-[(1S)-1-(4-Methoxyphenoxy)prop-2-en-1-yl]tetrahydrofuran-2-yl\}methanol (11). Allylmagnesium bromide (10.0 mL, $10.0 \mathrm{mmol}, 1.0 \mathrm{M}$ solution in diethyl ether) was added to a suspension of copper(I) cyanide $(97.6 \mathrm{mg}, 1.09 \mathrm{mmol})$ in anhydrous diethyl ether $(20 \mathrm{~mL})$ at -78 ${ }^{\circ} \mathrm{C}$ under an atmosphere of argon. The mixture was stirred for 30 minutes, before a solution of (2S)-2-[(1S)-1-(4-methoxyphenoxy)prop-2-en-1-yl]oxirane (1.107 g, $5.37 \mathrm{mmol})$ in anhydrous diethyl ether $(30 \mathrm{~mL})$ was added via a cannula and the resulting reaction mixture was stirred for ca. 3 hours (t.l.c. control). The reaction was then quenched by addition of saturated aqueous ammonium chloride solution and partitioned between diethyl ether and water. The combined organic phases were washed with brine, dried $\left(\mathrm{Na}_{2} \mathrm{SO}_{4}\right)$, filtered and concentrated in vacuo to afford a crude oil. Purification by flash column chromatography (eluting with 20\% ethyl acetate/hexanes) furnished the alcohol $(1.195 \mathrm{~g}, 90 \%)$ as a colorless liquid: $[\alpha]_{\mathrm{D}}{ }^{20}+19.0(\mathrm{c}=1.11$, $\mathrm{CHCl}_{3}$ ); IR (neat) 3468 (bm), 3077 (m), 2948 (m), 1641 (m), 1592 (w), 1506 (s), 1227 (s), 1038 (s), $994(\mathrm{~m}), 825(\mathrm{~s}) \mathrm{cm}^{-1} ;{ }^{1} \mathrm{H}$ NMR (400 MHz, $\left.\mathrm{CDCl}_{3}\right) \delta$ 6.88-6.85 (m, 2H), 6.82-6.79 (m, 2H), 5.90-5.78 (m, 2H), $5.31(\mathrm{~d}, J=15.3 \mathrm{~Hz}, 1 \mathrm{H}), 5.31$ (d, $J=13.6 \mathrm{~Hz}, 1 \mathrm{H}), 5.07$ (dd, $J=17.1,1.5 \mathrm{~Hz}$, 1H), 4.99 (d, $J=10.1 \mathrm{~Hz}, 1 \mathrm{H}), 4.34$ (t, $J=6.6 \mathrm{~Hz}, 1 \mathrm{H}), 3.76-3.71(\mathrm{~m}, 1 \mathrm{H}), 3.75$ (s, $3 \mathrm{H}), 2.70$ (br $\mathrm{s}, 1 \mathrm{H}), 2.38-2.29(\mathrm{~m}, 1 \mathrm{H}), 2.25-2.16(\mathrm{~m}, 1 \mathrm{H}), 1.75-1.55(\mathrm{~m}, 2 \mathrm{H}) ;{ }^{13} \mathrm{C} \mathrm{NMR}\left(100 \mathrm{MHz}, \mathrm{CDCl}_{6}\right) \delta$ 154.30 (e), 151.88 (e), 138.23 (o), 134.69 (o), 119.37 (e), 117.72 (o), 114.79 (e), 114.44 (o), 84.20 (o), 72.88 (o), 55.53 (o), 31.60 (e), 29.69 (e); HRMS (EI, $\mathrm{M}^{+}$) calcd for $\mathrm{C}_{15} \mathrm{H}_{20} \mathrm{O}_{3}$ 248.1412, found 248.1403. 
$\mathrm{Co}(\operatorname{modp})_{2}(358 \mathrm{mg}, 0.665 \mathrm{mmol})$ and a solution of tert-butyl hydroperoxide $(1.21 \mathrm{~mL}$, $6.65 \mathrm{mmol}, 5.0-6.0 \mathrm{M}$ in decane) were added to the alcohol (1.65 g, $6.65 \mathrm{mmol})$ in 2-propanol (95 $\mathrm{mL}$ ) and the resulting reaction ad mixture was stirred at $60{ }^{\circ} \mathrm{C}$ under an atmosphere of oxygen for ca. 24 hours (t.l.c. control). The mixture was cooled to room temperature and quenched by addition of saturated aqueous sodium thiosulfate $\left(\mathrm{Na}_{2} \mathrm{~S}_{2} \mathrm{O}_{3}\right)$ solution and stirred for an additional ca. 30 minutes. The reaction was concentrated in vacuo to remove most of the 2-propanol, and the crude reaction mixture partitioned between ethyl acetate and water. The combined organic phases were washed with water, brine, dried $\left(\mathrm{Na}_{2} \mathrm{SO}_{4}\right)$, filtered and concentrated in vacuo to afford a crude oil. Purification by flash column chromatography (eluting with 20-40\% ethyl acetate/hexanes) furnished the alcohol $11(1.459 \mathrm{~g}, 83 \%)$ as a colorless oil: $[\alpha]_{\mathrm{D}}{ }^{22}-1.6(\mathrm{c}=1.19$, $\mathrm{CHCl}_{3}$ ); IR (neat) 3445 (m), 3076 (w), 2934 (s), 1644 (w), 1591 (w), 1506 (vs), 1227 (s), 1039 (s), $826(\mathrm{~s}) \mathrm{cm}^{-1} ;{ }^{1} \mathrm{H}$ NMR (400 MHz, $\mathrm{CDCl}_{3}$ ) $\delta$ 6.89-6.84 (m, $\left.2 \mathrm{H}\right), 6.81-6.77(\mathrm{~m}, 2 \mathrm{H}), 5.85$ (ddd, $J=17.3,10.8,6.4 \mathrm{~Hz}, 1 \mathrm{H}), 5.33(\mathrm{dt}, J=17.5,1.3 \mathrm{~Hz}, 1 \mathrm{H}), 5.28(\mathrm{dt}, J=10.6,1.2 \mathrm{~Hz}, 1 \mathrm{H}), 4.49$ (t, $J=6.0 \mathrm{~Hz}, 1 \mathrm{H}), 4.24-4.16(\mathrm{~m}, 2 \mathrm{H}), 3.75(\mathrm{~s}, 3 \mathrm{H}), 3.70\left(\mathrm{dd}, \mathrm{A}\right.$ of ABX, $J_{A B}=11.7, J_{A X}=3.2 \mathrm{~Hz}$, $1 \mathrm{H}), 3.52\left(\mathrm{dd}, \mathrm{B}\right.$ of $\left.\mathrm{ABX}, J_{A B}=11.7, J_{B X}=5.6 \mathrm{~Hz}, 1 \mathrm{H}\right), 2.07-1.96(\mathrm{~m}, 3 \mathrm{H}), 1.90-1.70(\mathrm{~m}, 2 \mathrm{H}) ;{ }^{13} \mathrm{C}$ NMR (100 MHz, $\mathrm{CDCl}_{3}$ ) $\delta 154.06$ (e), 152.19 (e), 134.48 (o), 118.72 (e), 117.56 (o), 114.39 (o), 82.47 (o), 80.89 (o), 80.20 (o), 64.67 (e), 55.62 (o), 28.18 (e), 27.35 (e); HRMS (CI, M $^{+}$) calcd for $\mathrm{C}_{15} \mathrm{H}_{20} \mathrm{O}_{4}$ 264.1362, found 264.1359.

\section{(2R,5S)-2-Hept-6-yn-1-yl-5-[(1S)-1-(4-methoxyphenoxy)prop-2-en-1-yl]tetrahydrofuran (3).}

Triethylamine $(2.7 \mathrm{~mL}, 19.5 \mathrm{mmol})$ and triflic anhydride $(2.3 \mathrm{~mL}, 13.6 \mathrm{mmol})$ were sequential added to the alcohol $11(2.58 \mathrm{~g}, 9.77 \mathrm{mmol})$ in anhydrous dichloromethane $(98 \mathrm{~mL})$ at $-78{ }^{\circ} \mathrm{C}$ under an atmosphere of argon. The reaction was stirred at this temperature for $c a$. 1 hour, then quenched with saturated aqueous ammonium chloride solution and partitioned between dichlorormethane and water. The combined organic phases were washed with brine, dried $\left(\mathrm{Na}_{2} \mathrm{SO}_{4}\right)$, filtered and concentrated in vacuo to afford a crude oil. Purification by flash column chromatography (eluting with 30\% diethyl ether/pentane) furnished the primary triflate (3.489 g, $90 \%$ ) as a colorless liquid, which was immediately used in next reaction.

6-Trimethylsilyl-5-hexynylmagnesium bromide (53 mL, $26.43 \mathrm{mmol}$, ca. $0.5 \mathrm{M}$ solution in tetrahydrofuran) was added to a suspension of copper(I) iodide (335 mg, $1.762 \mathrm{mmol}$ ) in anhydrous tetrahydrofuran $(8 \mathrm{~mL})$ at $-78{ }^{\circ} \mathrm{C}$ under an atmosphere of argon. The reaction was 
stirred for ca. 30 minutes before the addition of the primary triflate $(3.488 \mathrm{~g}, 8.81 \mathrm{mmol})$ in anhydrous tetrahydrofuran $(80 \mathrm{~mL})$ via a Teflon cannula. The reaction flask was placed in a -20 ${ }^{\circ} \mathrm{C}$ cooling bath and allowed to warm up to $-10{ }^{\circ} \mathrm{C}$ over $\mathrm{ca} .1$ hour while the color of the reaction mixture changed from gray to light brown (t.l.c. control). The reaction was carefully quenched by the addition of methanol $(5 \mathrm{~mL})$ at $-20{ }^{\circ} \mathrm{C}$. Tetrabutylammonium fluoride $(40 \mathrm{~mL}, 40 \mathrm{mmol}, 1 \mathrm{M}$ solution in tetrahydrofuran) was then added and the resulting mixture allowed to warm to room temperature and stirred for $c a .16$ hours (t.l.c. control). The reaction was partitioned between saturated aqueous ammonium chloride solution and ethyl acetate. The combined organic phases were washed with water, brine, dried $\left(\mathrm{Na}_{2} \mathrm{SO}_{4}\right)$, filtered and concentrated in vacuo to afford a crude oil. Purification by flash column chromatography (eluting with 2-4\% diethyl ether/hexanes) furnished the alkyne $3(2.123 \mathrm{~g}, 73 \%)$ as a colorless liquid: $[\alpha]_{\mathrm{D}}{ }^{20}-16.8\left(\mathrm{c}=1.48, \mathrm{CHCl}_{3}\right)$; IR (neat) $3295(\mathrm{w}), 2935$ (m), $2116(\mathrm{w}), 1643$ (w), 1591 (w), 1507 (vs), 1229 (s), 1040 (m), 825 (m) $\mathrm{cm}^{-1} ;{ }^{1} \mathrm{H}$ NMR $\left(400 \mathrm{MHz}, \mathrm{CDCl}_{3}\right) \delta$ 6.89-6.85 (m, 2H), 6.80-6.76 (m, 2H), 5.86 (ddd, $J=17.3$, $10.8,6.2 \mathrm{~Hz}, 1 \mathrm{H}), 5.32(\mathrm{dt}, J=17.4,1.3 \mathrm{~Hz}, 1 \mathrm{H}), 5.28(\mathrm{dt}, J=10.6,1.2 \mathrm{~Hz}, 1 \mathrm{H}), 4.51(\mathrm{t}, J=5.8$ $\mathrm{Hz}, 1 \mathrm{H}), 4.20(\mathrm{dd}, J=13.6,6.6 \mathrm{~Hz}, 1 \mathrm{H}), 4.02-3.95(\mathrm{~m}, 1 \mathrm{H}), 3.75$ (s, $3 \mathrm{H}), 2.18$ (dt, J = 7.0, $2.7 \mathrm{~Hz}$, 2H), 2.07-1.96 (m, 2H), $1.93(\mathrm{t}, J=2.7 \mathrm{~Hz}, 1 \mathrm{H}), 1.87-1.78(\mathrm{~m}, 1 \mathrm{H}), 1.69-1.25(\mathrm{~m}, 9 \mathrm{H}) ;{ }^{13} \mathrm{C} \mathrm{NMR}$ (100 MHz, $\mathrm{CDCl}_{3}$ ) $\delta 153.89$ (e), 152.42 (e), 134.69 (o), 118.28 (e), 117.45 (o), 114.29 (o), 84.60 (e), 82.20 (o), 79.93 (o),79.85 (o), 68.10 (e), 55.57 (o), 35.47 (e), 31.87 (e), 28.74 (e), 28.36 (e), 27.81 (e), 25.58 (e), 18.28 (e); HRMS (CI, M+) calcd for $\mathrm{C}_{21} \mathrm{H}_{28} \mathrm{O}_{3}$ 328.2033, found 328.2033.

$O$-[(1S)-5,5-Diethoxy-1-methylpent-3-yn-1-yl) $S e$-phenyl selenocarbonate (13). $n$-Butyllithium (15.0 mL, $37.4 \mathrm{mmol}, 2.5 \mathrm{M}$ solution in hexanes) was added to alkyne 12 (4.396 g, $34.3 \mathrm{mmol})$ and HMPA $(26 \mathrm{~mL})$ in anhydrous tetrahydrofuran $(22 \mathrm{~mL})$ at $-30{ }^{\circ} \mathrm{C}$ under an atmosphere of argon. The reaction was stirred for ca. 5 minutes then $(S)$-propylene oxide 6 (2.904 g, $50.0 \mathrm{mmol})$ in anhydrous tetrahydrofuran $(13 \mathrm{~mL})$ was added via a Teflon cannula. The reaction mixture was stirred at $-30{ }^{\circ} \mathrm{C}$ for 2 hours and then at room temperature for additional ca. 2 hours (t.l.c. control). The reaction was quenched by addition of saturated aqueous ammonium chloride solution and partitioned between ethyl acetate and water. The combined organic phases were washed with brine, dried $\left(\mathrm{Na}_{2} \mathrm{SO}_{4}\right)$, filtered and evaporated in vacuo to afford a liquid residue. Purification by flash column chromatography (eluting with 5-40\% ethyl acetate/hexanes) furnished the secondary alcohol $(6.32 \mathrm{~g}, 99 \%)$ as a light brown color liquid: $[\alpha]_{\mathrm{D}}{ }^{24}+10.4\left(\mathrm{c}=1.03, \mathrm{CHCl}_{3}\right) ; \quad \mathrm{IR}$ (neat) 
3435 (m), 2977 (s), 2244 (w), 1356 (m), 1330 (m), 1052 (vs), 942 (m) cm ${ }^{-1}$; ${ }^{1} \mathrm{H}$ NMR (400 MHz, $\left.\mathrm{CDCl}_{3}\right) \delta 5.23(\mathrm{~s}, 1 \mathrm{H}), 3.93$ (heptet, $\left.J=5.7 \mathrm{~Hz}, 1 \mathrm{H}\right), 3.73-3.66(\mathrm{~m}, 2 \mathrm{H}), 3.57-3.50(\mathrm{~m}, 2 \mathrm{H}), 2.48$ $(\mathrm{d}, J=2.6 \mathrm{~Hz}, 1 \mathrm{H}), 2.38(\mathrm{dd}, J=5.9,1.2 \mathrm{~Hz}, 2 \mathrm{H}), 1.22(\mathrm{~d}, J=6.3 \mathrm{~Hz}, 3 \mathrm{H}) 1.19$ (t, $J=7.1 \mathrm{~Hz}$, 6H); ${ }^{13} \mathrm{C} \mathrm{NMR} \mathrm{(100} \mathrm{MHz,} \mathrm{CDCl}_{3}$ ) $\delta 91.24$ (o), 82.72 (e), 77.90 (e), 66.06 (o), 60.63 (e), 29.05 (e), 22.30 (o), 14.95 (o); HRMS (CI, M-H') calcd for $\mathrm{C}_{10} \mathrm{H}_{17} \mathrm{O}_{3}$ 185.1172, found 185.1175.

Phosgene (9.6 mL, $18.2 \mathrm{mmol}, 20 \%$ solution in toluene) was added to the secondary alcohol $(2.614 \mathrm{~g}, 14.0 \mathrm{mmol})$ in benzene $(130 \mathrm{~mL})$ at $0{ }^{\circ} \mathrm{C}$, followed by triethylamine $(2.3 \mathrm{~mL}$, $16.8 \mathrm{mmol})$. The reaction mixture was allowed to warm to room temperature and stirred for $\mathrm{ca} .16$ hours. Selenophenol freshly prepared from reduction of diphenyl diselenide (6.555 g, $21.0 \mathrm{mmol})$ with hypophosphorus acid $(14.5 \mathrm{~mL}, 140 \mathrm{mmol}, 50 \%$ solution in water) in benzene (130 $\mathrm{mL}) /$ tetrahydrofuran $(140 \mathrm{~mL})$ was added to the crude solution of chloroformate at $0{ }^{\circ} \mathrm{C}$ followed by the addition of pyridine $(11.3 \mathrm{~mL}, 140 \mathrm{mmol})$. The reaction mixture was then allowed to warm to room temperature and stirred for $c a$. 16 hours (t.l.c. control), before being diluted with diethyl ether, filtered through a pad of celite and concentrated in vacuo to afford a crude oil. Purification by flash column chromatography (eluting with $20 \%$ ethyl acetate/hexanes) furnished the selenocarbonate $13(3.14 \mathrm{~g}, 61 \%)$ as a colorless viscous liquid: $[\alpha]_{\mathrm{D}}{ }^{23}-30.6\left(\mathrm{c}=1.16, \mathrm{CHCl}_{3}\right)$; IR (neat) $3060(\mathrm{w}), 2977(\mathrm{~m}), 2248(\mathrm{w}), 1728(\mathrm{~s}), 1579(\mathrm{w}), 1479(\mathrm{~m}), 1440(\mathrm{~m}), 1120$ (s), 1051 (s), $741(\mathrm{~m}) \mathrm{cm}^{-1} ;{ }^{1} \mathrm{H}$ NMR (400 MHz, $\left.\mathrm{CDCl}_{3}\right) \delta$ 7.63-7.61 (m, $\left.2 \mathrm{H}\right), 7.40-7.34(\mathrm{~m}, 3 \mathrm{H}), 5.26(\mathrm{t}, J=$ $1.6 \mathrm{~Hz}, 1 \mathrm{H}), 5.14$ (sextet, $J=6.2 \mathrm{~Hz}, 1 \mathrm{H}), 3.78-3.70(\mathrm{~m}, 2 \mathrm{H}), 3.62-3.54(\mathrm{~m}, 2 \mathrm{H}), 2.62$ (ddd, A of $\left.\mathrm{ABXY}, J_{A B}=16.8, J_{A X}=5.5, J_{A Y}=1.5 \mathrm{~Hz}, 1 \mathrm{H}\right), 2.55\left(\mathrm{ddd}, \mathrm{B}\right.$ of $\mathrm{ABXY}, J_{A B}=16.8, J_{B X}=6.6, J_{B Y}=$ $1.6 \mathrm{~Hz}, 1 \mathrm{H}), 1.40(\mathrm{~d}, J=6.3 \mathrm{~Hz}, 3 \mathrm{H}), 1.24(\mathrm{t}, J=7.1 \mathrm{~Hz}, 6 \mathrm{H}) ;{ }^{13} \mathrm{C} \mathrm{NMR}\left(100 \mathrm{MHz}, \mathrm{CDCl}_{3}\right) \delta$ 166.30 (e), 135.69 (o), 129.23 (o), 129.08 (o), 125.93 (e), 91.24(o), 80.86 (e), 78.25 (e), 73.03 (o), 60.70 (e), 25.78 (e), 19.31 (o), 15.05 (o); HRMS (FAB, M+Na ${ }^{+}$) calcd for $\mathrm{C}_{17} \mathrm{H}_{22} \mathrm{O}_{4} \mathrm{NaSe}$ 393.0581, found 393.0589.

[(5S)-5-Methyl-2-oxo-2,5-dihydrofuran-3-yl]acetaldehyde (4). Tributyltin hydride (5.9 mL, $22.0 \mathrm{mmol}$ ) and 2,2'-azobisisobutyronitrile (AIBN) (361 mg, $2.20 \mathrm{mmol})$ in anhydrous benzene (40 $\mathrm{mL}$ ) were added via syringe pump to a refluxing solution of the selenocarbonate 13 (3.699 $\mathrm{g}$, $10.02 \mathrm{mmol}$ ) in anhydrous benzene (1 L) over ca. 12 hours under an atmosphere of argon. The reaction was then refluxed for additional $c a .2$ hours (t.l.c. control), cooled to room temperature and concentrated in vacuo to afford a crude oil. Purification by flash column chromatography 
(eluting with 10-30\% ethyl acetate/hexanes) afforded the butenolide (1.72 g, 80\%) as a colorless liquid of a mixture of E,Z-isomers: IR (neat) 2978 (s), 1762 (vs), 1686 (m), 1206 (s), 1055 (s) cm ${ }^{1}$; ${ }^{1} \mathrm{H} \mathrm{NMR}\left(400 \mathrm{MHz}, \mathrm{CDCl}_{3}\right.$ ) (major isomer) $\delta 6.66(\mathrm{dt}, J=4.8,3.0 \mathrm{~Hz}, 1 \mathrm{H}), 5.17(\mathrm{dt}, J=4.7$, $1.3 \mathrm{~Hz}, 1 \mathrm{H}), 4.71-4.63(\mathrm{~m}, 1 \mathrm{H}), 3.68-3.60$ (m, 2H), 3.57-3.50 (m, 2H), 3.19 (dddd, $J=17.9,7.6$, 2.8, $1.3 \mathrm{~Hz}, 1 \mathrm{H}), 2.56$ (dddd, $J=17.9,5.9,3.2,1.6 \mathrm{~Hz}, 1 \mathrm{H}), 1.42(\mathrm{~d}, J=6.3 \mathrm{~Hz}, 3 \mathrm{H}), 1.22(\mathrm{t}, J=$ $7.0 \mathrm{~Hz}, 6 \mathrm{H}) ;{ }^{13} \mathrm{C}$ NMR (100 MHz, $\mathrm{CDCl}_{3}$ ) $\delta 170.61$ (e), 135.11 (o), 130.30 (e), 98.41 (o), 74.45 (o), 60.91 (e), 60.86 (e), 33.55 (e), 22.16 (o), 15.21 (o); HRMS (FAB, M+Na ${ }^{+}$) calcd for $\mathrm{C}_{11} \mathrm{H}_{18} \mathrm{O}_{4} \mathrm{Na} 237.1103$, found 237.1110.

Carbonylhydrotris(triphenylphosphine) rhodium(I) $(763 \mathrm{mg}, 0.83 \mathrm{mmol}$ ) was added to an isomeric mixture of butenolides $(3.55 \mathrm{~g}, 16.6 \mathrm{mmol})$ in anhydrous benzene $(160 \mathrm{~mL})$ and the resulting solution heated at $85{ }^{\circ} \mathrm{C}$ for ca. 16 hours under an atmosphere of argon (t.l.c. control). The reaction mixture was allowed to cool to room temperature and concentrated in vacuo to afford a crude oil. Purification by flash column chromatography (eluting with 10-30\% ethyl acetate/hexanes) furnished the isomerized butenolide $(2.97 \mathrm{~g}, 84 \%)$ as a colorless liquid: $[\alpha]_{\mathrm{D}}{ }^{22}$ +35.9 (c = 1.25, $\mathrm{CHCl}_{3}$ ); IR (neat) 2978 (s), 2933 (m), 2252 (m), 1755 (vs), 1655 (m), 1320 (m), 1060 (s), $733(\mathrm{~m}) \mathrm{cm}^{-1} ;{ }^{1} \mathrm{H}$ NMR (400 MHz, $\left.\mathrm{CDCl}_{3}\right) \delta 7.14(\mathrm{~d}, J=1.3 \mathrm{~Hz}, 1 \mathrm{H}), 4.96$ (dq, $J=6.8$, $1.5 \mathrm{~Hz}, 1 \mathrm{H}), 4.66(\mathrm{t}, J=5.6 \mathrm{~Hz}, 1 \mathrm{H}), 3.64-3.56(\mathrm{~m}, 2 \mathrm{H}), 3.48-3.40(\mathrm{~m}, 2 \mathrm{H}), 2.53(\mathrm{~d}, J=5.6 \mathrm{~Hz}$, $2 \mathrm{H}), 1.34(\mathrm{~d}, J=6.8 \mathrm{~Hz}, 3 \mathrm{H}), 1.11(\mathrm{t}, J=7.0 \mathrm{~Hz}, 6 \mathrm{H}) ;{ }^{13} \mathrm{C} \mathrm{NMR}\left(100 \mathrm{MHz}, \mathrm{CDCl}_{3}\right) \delta 173.55(\mathrm{e})$, 151.66 (o), 128.89 (e), 100.23 (o), 77.56 (o), 61.56 (e), 29.72 (e), 18.84 (o), 15.04 (o); HRMS $\left(\mathrm{FAB}, \mathrm{M}+\mathrm{Na}^{+}\right.$) calcd for $\mathrm{C}_{11} \mathrm{H}_{18} \mathrm{O}_{4} \mathrm{Na} 237.1103$, found 237.1104.

Formic acid $(1.2 \mathrm{~mL}, 31.7 \mathrm{mmol})$ was added to the butenolide $(576.5 \mathrm{mg}, 2.69 \mathrm{mmol})$ in anhydrous pentane $(2 \mathrm{~mL})$ at $0{ }^{\circ} \mathrm{C}$ under an atmosphere of argon. The reaction was allowed to warm to room temperature, and stirred for $c a .3$ hours (t.l.c. control). The reaction was re-cooled to $0{ }^{\circ} \mathrm{C}$ and partitioned between dichloromethane and pre-cooled brine and saturated aqueous sodium bicarbonate solutions. The aqueous layers were re-extracted with dichloromethane, and the combined organic extracts were dried $\left(\mathrm{MgSO}_{4}\right)$, filtered and concentrated in vacuo to furnish

the crude aldehyde 4 (338 mg, 90\%) as a colorless liquid. The aldehyde 4 proved to be quite unstable and used immediately in the next step to minimize decomposition.

$(5 S)-3-\{(2 S)-9-\{(2 R, 5 S)-5-[(1 S)-1-H y d r o x y p r o p-2-e n-1-y l]$ tetrahydrofuran-2-yl $\}-2-$ [(triisopropylsilyl)oxy]non-3-yn-1-yl\}-5-methylfuran-2(5H)-one (14). Diethylzinc (0.94 mL, 
$9.0 \mathrm{mmol})$ was added to the alkyne $3(2.961 \mathrm{~g}, 9.015 \mathrm{mmol})$ in anhydrous toluene $(4.5 \mathrm{~mL})$ and the mixture refluxed for $c a$. 1 hour. The resulting clear solution was then allowed to cool to room temperature. Titanium(IV) isopropoxide $(1.38 \mathrm{~mL}, 4.69 \mathrm{mmol})$ was added to $R$-(+)-BINOL (430 $\mathrm{mg}, 1.5 \mathrm{mmol})$ in anhydrous tetrahydrofuran $(24 \mathrm{~mL})$ at room temperature. The mixture was cooled to $0{ }^{\circ} \mathrm{C}$ and stirred for $c a .15$ minutes before the pre-cooled alkynyl zinc reagent was added, and the reaction stirred at $0{ }^{\circ} \mathrm{C}$ for an additional $c a .1$ hour resulting in a clear light orange colored reaction mixture. The freshly prepared aldehyde 4 (219 mg, $1.563 \mathrm{mmol})$ was then added dropwise via tared syringe at $0{ }^{\circ} \mathrm{C}$, and the reaction mixture stirred for $c a .5$ hours. The reaction was then quenched by addition of saturated aqueous ammonium chloride solution, filtered washing with diethyl ether, and the filtrate partitioned between diethyl ether and water. The combined organic phases were washed with brine, dried $\left(\mathrm{Na}_{2} \mathrm{SO}_{4}\right)$ and concentrated in vacuo to afford a crude oil. Purfication by flash column chromatography (eluting with 15-60\% diethyl ether/pentane) furnished the propargylic alcohol (593 mg, 81\%) as a colorless viscous liquid. The ratio of diastereoisomers of the alcohol was determined to be 20/1 (on the crude mixture) by HPLC (Zorbax 2276 column, 3\% isopropanol in hexane, $1.0 \mathrm{~mL} / \mathrm{min}$, retention time: $\mathrm{t}_{\text {major }}=48.42$ min and $\mathrm{t}_{\text {minor }}=54.20 \mathrm{~min}$ ) whereas $d s$ of $22 / 1$ was obtained for purified product by HPLC: $[\alpha]_{\mathrm{D}}{ }^{22}$ +7.0 (c = 1.12, $\mathrm{CHCl}_{3}$ ); IR (neat) 3419 (s), 3078 (m), 2933 (vs), 2228 (m), 1756 (vs), 1652 (m), 1591 (m), 1505 (vs), 1464 (s), 1228 (s), 1038 (s), 826 (s) cm ${ }^{-1} ;{ }^{1} \mathrm{H}$ NMR (400 MHz, CDCl ${ }_{3}$ ) 7.23 (q, $J=1.3 \mathrm{~Hz}, 1 \mathrm{H}), 6.88-6.84(\mathrm{~m}, 2 \mathrm{H}), 6.79-6.75(\mathrm{~m}, 2 \mathrm{H}), 5.84(\mathrm{ddd}, J=17.2,10.8,6.3 \mathrm{~Hz}, 1 \mathrm{H})$, $5.31(\mathrm{~d}, J=17.5 \mathrm{~Hz}, 1 \mathrm{H}), 5.26(\mathrm{~d}, J=10.7 \mathrm{~Hz}, 1 \mathrm{H}), 5.03(\mathrm{dq}, J=6.8,0.8 \mathrm{~Hz}, 1 \mathrm{H}), 4.60(\mathrm{q}, J=5.9$ $\mathrm{Hz}, 1 \mathrm{H}), 4.48(\mathrm{t}, J=5.9 \mathrm{~Hz}, 1 \mathrm{H}), 4.18(\mathrm{dd}, J=13.7,6.6 \mathrm{~Hz}, 1 \mathrm{H}), 4.00-3.94$ (m, 1H), 3.73 (s, 3H), 3.02 (br s, 1H), 2.67 (d, $J=5.9 \mathrm{~Hz}, 2 \mathrm{H}), 2.15$ (dt, $J=7.0,1.6 \mathrm{~Hz}, 2 \mathrm{H}), 2.06-1.95(\mathrm{~m}, 2 \mathrm{H}), 1.85-$ $1.76(\mathrm{~m}, 1 \mathrm{H}), 1.65-1.25(\mathrm{~m}, 9 \mathrm{H}), 1.41(\mathrm{~d}, J=6.8 \mathrm{~Hz}, 3 \mathrm{H}) ;{ }^{13} \mathrm{C} \mathrm{NMR}\left(100 \mathrm{MHz}, \mathrm{CDCl}_{3}\right) \delta 174.15$ (e), 153.67 (e), 152.42 (o), 152.17 (e), 134.43 (o), 129.48 (e), 118.23 (e), 117.28 (o), 114.11 (o), 85.72 (e), 82.08 (o), 80.02 (e), 79.79 (o), 79.66 (o), 77.91 (o), 60.23 (o), 55.39 (o), 35.22 (e), 33.78 (e), 31.67 (e), 28.63 (e), 28.20 (e), 27.69 (e), 25.34 (e), 18.78 (o), 10.31 (e); HRMS (FAB, $\mathrm{M}+\mathrm{Na}^{+}$) calcd for $\mathrm{C}_{28} \mathrm{H}_{36} \mathrm{NaO}_{6} 491.2410$, found 491.2414.

The propargylic alcohol $(90.3 \mathrm{mg}, 0.193 \mathrm{mmol})$ in anhydrous tetrahydrofuran $(1.0 \mathrm{~mL})$ was cooled with stirring to $0{ }^{\circ} \mathrm{C}$ under an atmosphere of argon. Anhydrous pyridine (32 $\mu \mathrm{L}, 0.4$ mmol), DMAP (2.2 mg, $0.02 \mathrm{mmol})$ and triisopropylsilyl triflate $(59 \mu \mathrm{L}, 0.22 \mathrm{mmol})$ were sequentially added, and the resulting reaction mixture was stirred at $0{ }^{\circ} \mathrm{C}$ for $\mathrm{ca} .3$ hours (t.l.c. 
control). The reaction was then quenched by the addition of saturated aqueous ammonium chloride solution and partitioned between ethyl acetate and water. The combined organic phases were washed with brine, filtered, dried $\left(\mathrm{Na}_{2} \mathrm{SO}_{4}\right)$ and concentrated in vacuo to afford a crude oil. Purification by flash column chromatography (eluting with $15 \%$ ethyl acetate/hexanes) furnished the triisopropylsilyl ether $(115.8 \mathrm{mg}, 96 \%)$ as a colorless liquid: $[\alpha]_{\mathrm{D}}^{23}-16.0\left(\mathrm{c}=1.16, \mathrm{CHCl}_{3}\right)$; IR (neat) 3078 (w), 2940 (s), 2865 (s), 2233 (s), 1759 (vs), 1655 (w), 1591 (w), 1507 (vs), 1229

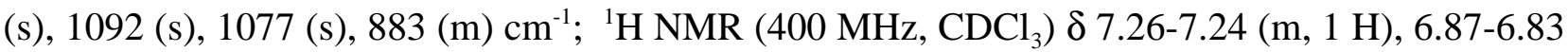
(m, 2H), 6.78-6.74 (m, 2H), $5.84(\mathrm{ddd}, J=17.2,10.8,6.2 \mathrm{~Hz}, 1 \mathrm{H}), 5.31(\mathrm{~d}, J=17.5 \mathrm{~Hz}, 1 \mathrm{H}), 5.25$ $(\mathrm{d}, J=10.6 \mathrm{~Hz}, 1 \mathrm{H}), 5.00(\mathrm{dq}, J=6.7,1.2 \mathrm{~Hz}, 1 \mathrm{H}), 4.73(\mathrm{tt}, J=6.0,1.7 \mathrm{~Hz}, 1 \mathrm{H}), 4.48(\mathrm{t}, J=5.8$ $\mathrm{Hz}, 1 \mathrm{H}), 4.18(\mathrm{dd}, J=13.6,6.6 \mathrm{~Hz}, 1 \mathrm{H}), 3.99-3.93(\mathrm{~m}, 1 \mathrm{H}), 3.72$ (s, 3H), 2.64 (dd, J = 6.0, $0.9 \mathrm{~Hz}$, 2H), $2.13(\mathrm{dt}, J=7.0,1.6 \mathrm{~Hz}, 2 \mathrm{H}), 2.06-1.94(\mathrm{~m}, 2 \mathrm{H}), 1.86-1.76(\mathrm{~m}, 1 \mathrm{H}), 1.65-1.0(\mathrm{~m}, 30 \mathrm{H}), 1.38$ $(\mathrm{d}, J=6.8 \mathrm{~Hz}, 3 \mathrm{H}) ;{ }^{13} \mathrm{C} \mathrm{NMR}\left(100 \mathrm{MHz}, \mathrm{CDCl}_{3}\right) \delta 173.76(\mathrm{e}), 153.82$ (e), 152.33 (e), 152.03 (o), 134.62 (o), 129.37 (e), 118.24 (e), 117.36 (o), 114.21 (o), 85.22 (e), 82.15 (o), 80.76 (e), 79.90 (o), 79.80 (o), 77.52 (o), 60.98 (o), 55.48 (o), 35.48 (e), 34.70 (e), 31.82 (e), 28.80 (e), 28.32 (e), 27.79 (e), 25.54 (e), 18.85 (o), 18.41 (e), 17.93 (o), 17.92 (o), 12.11 (o); HRMS (FAB, M+Na ${ }^{+}$calcd for $\mathrm{C}_{37} \mathrm{H}_{56} \mathrm{NaO}_{6} \mathrm{Si}$ 647.3744, found 647.3765.

Ceric ammonium nitrate $(1.415 \mathrm{~g}, 2.58 \mathrm{mmol})$ was added in a single portion to the triisopropylsilyl ether $(806.5 \mathrm{mg}, 1.29 \mathrm{mmol})$ in acetonitrile/water $(15 \mathrm{~mL}, 4: 1)$ at $-10{ }^{\circ} \mathrm{C}$ under an atmosphere of argon. The reaction was stirred for $c a .20$ minutes (t.l.c. control) and then partitioned between ethyl acetate and water. The combined organic phases were washed with brine, dried $\left(\mathrm{Na}_{2} \mathrm{SO}_{4}\right)$ and concentrated in vacuo to afford a crude oil. Purification by flash column chromatography (eluting with $8-15 \%$ ethyl acetate/hexanes) furnished the allylic alcohol $14(638.1 \mathrm{mg}, 95 \%)$ as a liquid: $[\alpha]_{\mathrm{D}}{ }^{25}-13.7\left(\mathrm{c}=1.09, \mathrm{CHCl}_{3}\right)$; IR (neat) $3482(\mathrm{~s}), 3080(\mathrm{~m})$, 2940 (vs), 2860 (vs), 2232 (m), 1760 (vs), 1657 (m), 1092 (s), 922 (s), 883 (s) cm ${ }^{-1}$; ${ }^{1} \mathrm{H}$ NMR (400 $\left.\mathrm{MHz} \mathrm{CDCl}_{3}\right) \delta 7.25(\mathrm{~s}, 1 \mathrm{H}), 5.79(\mathrm{ddd}, J=17.0,10.6,6.2 \mathrm{~Hz}, 1 \mathrm{H}), 5.35(\mathrm{~d}, J=17.2 \mathrm{~Hz}, 1 \mathrm{H})$, $5.20(\mathrm{~d}, J=10.5 \mathrm{~Hz}, 1 \mathrm{H}), 5.01(\mathrm{q}, J=6.4 \mathrm{~Hz}, 1 \mathrm{H}), 4.74(\mathrm{t}, J=5.9 \mathrm{~Hz}, 1 \mathrm{H}), 3.93-3.88(\mathrm{~m}, 2 \mathrm{H})$, $3.84(\mathrm{q}, J=7.0 \mathrm{~Hz}, 1 \mathrm{H}), 2.65(\mathrm{~d}, J=5.9 \mathrm{~Hz}, 2 \mathrm{H}), 2.54(\mathrm{~d}, J=3.1 \mathrm{~Hz}, 1 \mathrm{H}), 2.15$ (dt, $J$ 6.8, $1.3 \mathrm{~Hz}$, 2H), 2.06-1.91 (m, $2 \mathrm{H}), 1.70-1.05(\mathrm{~m}, 31 \mathrm{H}), 1.41(\mathrm{~d}, J=6.7 \mathrm{~Hz}, 3 \mathrm{H}) ;{ }^{13} \mathrm{C} \mathrm{NMR}(100 \mathrm{MHz}$, $\left.\mathrm{CDCl}_{3}\right) \delta 173.82$ (e), 152.04 (o), 136.76 (o), 129.48 (e), 116.95 (e), 85.21 (e), 81.41 (o), 80.85 (e), 79.32 (o), 77.57 (o), 75.57 (o), 61.04 (o), 35.44 (e), 34.75 (e), 32.05 (e), 28.82 (e), 28.35 (e), 27.89 
(e), 25.65 (e), 18.92 (o), 18.47 (e), 17.99 (o), 12.17 (o); HRMS (FAB, M+Na ${ }^{+}$) calcd for $\mathrm{C}_{30} \mathrm{H}_{50} \mathrm{NaO}_{5} \mathrm{Si} 541.3325$, found 541.3304.

$(5 S)-3-\{(2 S)-9-\{(2 R, 5 S)-5-[(4 S, 7 S)-7-((2 S, 5 R, 6 S)-5-\{[t e r t-B u t y l(d i m e t h y l) s i l y l] 0 x y\}-6-$ decyltetrahydro-2H-pyran-2-yl)-2,2-diisopropyl-4,7-dihydro-1,3,2-dioxasilepin-4yl]tetrahydrofuran-2-yl\}-2-[(triisopropylsilyl)oxy]non-3-yn-1-yl\}-5-methylfuran-2(5H)-one

(15). Dichlorodiisopropylsilane $(1.2 \mathrm{~mL}, 6.6 \mathrm{mmol})$ was added to imidazole $(136 \mathrm{mg}, 2.0 \mathrm{mmol})$ in anhydrous dichloromethane $(6 \mathrm{~mL})$ at $0{ }^{\circ} \mathrm{C}$ under an atmosphere of argon. The solution was stirred for ca. 5 minutes, then the allylic alcohol $2(235 \mathrm{mg}, 0.57 \mathrm{mmol})$ in dichloromethane (1 $\mathrm{mL}$ ) was added via syringe pump over $c a .1$ hour at $0{ }^{\circ} \mathrm{C}$. The reaction mixture was then allowed to warm up to room temperature and stirred for $c a$. 16 hours (t.l.c. control). The solvent was removed in vacuo and the residue was treated with anhydrous hexanes $(6 \mathrm{~mL})$ for $c a .10$ minutes, filtered through a glass-frit and the volatiles removed under high vacuum at $55{ }^{\circ} \mathrm{C}$ over $\mathrm{ca} .3$ hours. The residue was then redissolved in anhydrous dichloromethane $(3 \mathrm{~mL})$ and cooled with stirring to $0{ }^{\circ} \mathrm{C}$. Imidazole $(162 \mathrm{mg} 2.4 \mathrm{mmol})$ in dichloromethane $(3 \mathrm{~mL})$ was added dropwise followed by the alcohol $14(121 \mathrm{mg}, 0.23 \mathrm{mmol})$ in anhydrous dichloromethane $(0.5 \mathrm{~mL})$ and the mixture was allowed to warm up to room temperature over ca. 3 hours (t.l.c. control). The reaction mixture was then concentrated in vacuo to afford the crude oil, which was purified by flash chromatography (eluting with 2-4\% ethyl acetate/hexane) to afford the bis-alkoxy silane (181 $\mathrm{mg}, 74 \%)$ as a colorless oil: $[\alpha]_{\mathrm{D}}^{25}-54.3\left(\mathrm{c}=1.0, \mathrm{CHCl}_{3}\right)$; IR (neat) $2928(\mathrm{vs}), 2865(\mathrm{~s}), 2225$ (w), 1763 (s), 1642 (w), 1464 (m), 1094 (s), 884 (m), 837 (m), 775 (m); ${ }^{1} \mathrm{H}$ NMR (400 MHz, $\left.\mathrm{CDCl}_{3}\right) \delta 7.24(\mathrm{~s}, 1 \mathrm{H}), 5.84$ (ddd, $\left.J=17.0,10.9,5.8 \mathrm{~Hz}, 1 \mathrm{H}\right), 5.84$ (ddd, $J=16.7,11.1,4.9 \mathrm{~Hz}$, $1 \mathrm{H}), 5.29(\mathrm{~d}, J=18.0 \mathrm{~Hz}, 1 \mathrm{H}), 5.24(\mathrm{~d}, J=17.7 \mathrm{~Hz}, 1 \mathrm{H}), 5.13(\mathrm{~d}, J=12.2 \mathrm{~Hz}, 1 \mathrm{H}), 5.10(\mathrm{~d}, J=$ $12.2 \mathrm{~Hz}, 1 \mathrm{H}), 4.99(\mathrm{dq}, J=7.0,1.4 \mathrm{~Hz}, 1 \mathrm{H}), 4.72(\mathrm{t}, J=6.0 \mathrm{~Hz}, 1 \mathrm{H}), 4.41(\mathrm{q}, J=5.3 \mathrm{~Hz}, 2 \mathrm{H})$, $4.01(\mathrm{q}, J=6.7 \mathrm{~Hz}, 1 \mathrm{H}), 3.88-3.80(\mathrm{~m}, 1 \mathrm{H}), 3.33(\mathrm{ddd}, J=11.0,5.2,1.5 \mathrm{~Hz}, 1 \mathrm{H}), 3.18(\mathrm{dt}, J=9.5$, $4.3 \mathrm{~Hz}, 1 \mathrm{H}), 3.02-2.98(\mathrm{~m}, 1 \mathrm{H}), 2.63(\mathrm{~d}, J=6.1 \mathrm{~Hz}, 2 \mathrm{H}), 2.12(\mathrm{dt}, J=7.0,1.5 \mathrm{~Hz}, 2 \mathrm{H}), 1.96-1.81$ (m, 3H), 1.78-1.62 (m, 3H), 1.55-0.84 (m, 63H), 1.39 (d, J = 7.0 Hz, 3H), 0.85 (s, 12H), 0.02 (s, 6H); ${ }^{13} \mathrm{C}$ NMR (100 MHz, $\mathrm{CDCl}_{3}$ ) $\delta 174.00$ (e), 152.17 (o), 137.57 (o), 137.54 (o), 129.70 (e), 115.90 (e), 115.05 (e), 85.49 (e), 82.51 (o), 81.59 (o), 80.98 (e), 80.13 (o), 79.75 (o), 77.75 (o), 75.20 (o), 74.32 (e), 71.37 (o), 61.24 (o), 35.85 (e), 34.95 (e), 33.41 (e), 32.18 (e), 32.07, (e), 29.95 (e), 29.84 (e), 29.81 (e), 29.51 (e), 29.14 (e), 28.64 (e), 26.91 (e), 25.94 (o), 25.28 (e), 25.00 
(e), 22.83 (e), 19.12 (e), 18.69 (e), 18.16 (o), 18.10 (e), 17.53 (o), 17.50 (o), 14.27 (o), 12.90 (o), 12.86 (o), 12.37 (o), -3.83 (o), -4.62 (o); HRMS (FAB, M+Na+) calcd for $\mathrm{C}_{60} \mathrm{H}_{110} \mathrm{NaO}_{8} \mathrm{Si}_{3}$ 1065.7406, found 1065.7379.

Grubbs' catalyst $(70.8 \mathrm{mg}, 0.086 \mathrm{mmol})$ in anhydrous 1,2-dichloroethane $(10 \mathrm{~mL})$ was added via syringe pump over ca. 34 hours (t.l.c. control) to a refluxing solution of the bisalkoxysilane $(50.8 \mathrm{mg}, 0.048 \mathrm{mmol})$ in anhydrous 1,2-dichloroethane $(20 \mathrm{~mL}$, degassed for 5 minutes using argon). The reaction mixture was then allowed to cool to room temperature and concentrated in vасио to afford dark brown oil. Purification by flash chromatography (eluting with $2 \%$ acetonitrile/benzene) afforded the silaketal $15(41.2 \mathrm{mg}, 83 \%)$ as a colorless oil: $[\alpha]_{\mathrm{D}}{ }^{24}$ 66.5 (c = 1.13, $\mathrm{CHCl}_{3}$ ); IR (neat) 2928 (vs), 2864 (vs), 2225 (w), 1762 (s), 1653 (w), 1464 (m), 1094 (s), 885 (s), 837 (s), 775 (m), 684 (m); ${ }^{1} \mathrm{H}$ NMR (400 MHz, CDCl ${ }_{3}$ ) 7.24 (s, 1H), 5.73 (d, J $=12.5 \mathrm{~Hz}, 1 \mathrm{H}), 5.65(\mathrm{~d}, J=12.8 \mathrm{~Hz}, 1 \mathrm{H}), 4.99(\mathrm{dq}, J=6.8,1.4 \mathrm{~Hz}, 1 \mathrm{H}), 4.73-4.65(\mathrm{~m}, 3 \mathrm{H}), 4.08$ (dt, $J=7.1,4.4 \mathrm{~Hz}, 1 \mathrm{H}), 3.95-3.88(\mathrm{~m}, 1 \mathrm{H}), 3.39-3.32(\mathrm{~m}, 1 \mathrm{H}), 3.21(\mathrm{dt}, J=9.1,4.7 \mathrm{~Hz}, 1 \mathrm{H})$, 3.04-2.98 (m, 1H), $2.63(\mathrm{dd}, J=6.0,1.1 \mathrm{~Hz}, 2 \mathrm{H}), 2.12(\mathrm{dt}, J=6.9,1.6 \mathrm{~Hz}, 2 \mathrm{H}), 2.02-1.92(\mathrm{~m}$, 4H), 1.85-1.67 (m, 4H), 1.50-0.94 (m, 61H), $1.38(\mathrm{~d}, J=7.0,3 \mathrm{H}), 0.85(\mathrm{~s}, 9 \mathrm{H}), 0.85$ (t, J = 6.7 Hz, 3H), 0.02 (s, 6H); ${ }^{13} \mathrm{C}$ NMR (100 MHz, $\mathrm{CDCl}_{3}$ ) $\delta 174.03$ (e), 152.20 (o), 132.12 (o), 131.15 (o), 129.70 (e), 85.50 (e), 82.41 (o), 81.30 (o), 80.98 (e), 80.27 (o), 79.59 (o), 77.77 (o), 73.20 (o), 73.16 (o), 71.46 (o), 61.24 (o), 35.83 (e), 34.95 (e), 33.31 (e), 32.24 (e), 32.16 (e), 32.07 (e), 29.90 (e), 29.81 (e), 29.49 (e), 29.13 (e), 28.61 (e), 27.40 (e), 25.96 (o), 25.91 (e), 25.26 (e), 25.06 (e), 22.83 (e), 19.12 (o), 18.69 (e), 18.19 (o), 18.16 (o), 18.13 (e), 17.68 (o), 17.42 (o), 17.39 (o), 14.27 (o), 12.46 (o), 12.42 (o), 12.37 (o), -3.83 (o), -4.57 (o); HRMS (FAB, M+Na ${ }^{+}$) calcd for $\mathrm{C}_{58} \mathrm{H}_{106} \mathrm{NaO}_{8} \mathrm{Si}_{3}$ 1037.7093, found 1037.7113 .

Mucocin (1). 5\% HF/acetonitrile (0.4 mL) was added dropwise to the silaketal 15 (16 mg, 0.016 $\mathrm{mmol})$ in dichloromethane $(1.5 \mathrm{~mL})$ at room temperature. The mixture was stirred at room temperature for ca. 5 hours (t.l.c. control), and then phosphate buffer solution ( $2 \mathrm{~mL}, 1 \mathrm{M}, \mathrm{pH} 7)$ and water $(2 \mathrm{~mL})$ were added. The reaction mixture was extracted with chloroform/iso-propanol (1:1), and the combined organic layers were dried $\left(\mathrm{MgSO}_{4}\right)$, filtered and concentrated in vacuo to afford a crude oil. Purification by flash chromatography (eluting with $40 \%$ acetonitrile/benzene) furnished the tetraol $(9.1 \mathrm{mg}, 91 \%)$ as a white solid. $[\alpha]_{\mathrm{D}}{ }^{22}+6.2\left(\mathrm{c}=1.7, \mathrm{CHCl}_{3}\right)$; IR (neat) 3413 (br, m), 2926 (vs), 2855 (s), 1748 (s), 1655 (w), 1084 (s), 1028 (s) cm ${ }^{-1}$; ${ }^{1} \mathrm{H}$ NMR (400 MHz, 
$\left.\mathrm{CDCl}_{3}\right) \delta 7.23(\mathrm{~d}, J=1.5 \mathrm{~Hz}, 1 \mathrm{H}), 5.60-5.52(\mathrm{~m}, 2 \mathrm{H}), 5.04(\mathrm{dq}, J=6.8,1.4 \mathrm{~Hz}, 1 \mathrm{H}), 4.60(\mathrm{tt}, J=$ 6.0, $1.8 \mathrm{~Hz}, 1 \mathrm{H}), 4.27(\mathrm{t}, J=7.2 \mathrm{~Hz}, 1 \mathrm{H}), 4.24(\mathrm{t}, J=7.3 \mathrm{~Hz}, 1 \mathrm{H}), 3.94-3.86(\mathrm{~m}, 1 \mathrm{H}), 3.87(\mathrm{q}, J=$ $7.0 \mathrm{~Hz}, 1 \mathrm{H}), 3.27$ (dt, $J=9.6,4.6 \mathrm{~Hz}, 1 \mathrm{H}), 3.21-3.17(\mathrm{~m}, 1 \mathrm{H}), 3.06(\mathrm{dt}, J=8.9,2.1 \mathrm{~Hz}, 1 \mathrm{H}), 2.85$ (br s, 2H), 2.69 (d, $J=6.1 \mathrm{~Hz}, 2 \mathrm{H}), 2.17$ (dt, $J=6.8,1.8 \mathrm{~Hz}, 2 \mathrm{H}), 2.11-2.05(\mathrm{~m}, 1 \mathrm{H}), 2.04-1.89$ (m, 2H), 1.86-1.80 (m, 1H), 1.74-1.18 (m, 32H), 1.42 (d, J=7.0 Hz, 3H), 0.86 (t, J = 6.7 Hz, 3H); ${ }^{13} \mathrm{C} \mathrm{NMR}\left(100 \mathrm{MHz}, \mathrm{CDCl}_{3}\right.$ ) $\delta ; 174.43$ (e), 152.57 (o), 132.69 (o), 132.02 (o), 130.08 (e), 86.34 (e), 82.32 (o), 81.60 (o), 80.30 (e), 79.83 (o), 79.53 (o), 78.21 (o), 70.85 (o), 70.74 (o), 70.64 (o), 60.78 (o), 35.41 (e), 34.19 (e), 32.66 (e), 32.22 (e), 32.13 (e), 32.04 (e), 29.87 (e), 29.76 (e), 29.47 (e), 28.82 (e), 28.44 (e), 27.78 (e), 26.88 (e), 25.82 (e), 25.62 (e), 22.82 (e), 19.21 (o), 18.65 (e), 14.26 (o). HRMS (FAB, M+Na ${ }^{+}$) calcd for $\mathrm{C}_{37} \mathrm{H}_{60} \mathrm{NaO}_{8} 655.4186$, found 665.4198.

Sodium acetate $(120 \mathrm{mg}, 1.3 \mathrm{mmol})$ in distilled water $(1.3 \mathrm{~mL})$ was added over ca. 4 hours via syringe pump to a refluxing solution of the tetraol $(9.9 \mathrm{mg}, 0.016 \mathrm{mmol})$ and $p$-toluenesulfonyl hydrazine $(219 \mathrm{mg}, 1.1 \mathrm{mmol})$ in 1,2-dimethoxyethane $(1.5 \mathrm{~mL})$. The reaction mixture was stirred under reflux for an additional hour and cooled to room temperature. The reaction mixture was partitioned between water and chloroform/iso-propanol (1:1). The combined organic phases were dried $\left(\mathrm{MgSO}_{4}\right)$ and concentrated in vacuo to afford a crude oil. Purification by flash chromatography (eluting with $40 \%$ acetonitrile/benzene) furnished mucocin (1) $(9.5 \mathrm{mg}, 95 \%)$ as a white solid. HPLC Chromegasorb SI60, $5 \mu, 60 \AA$, $25 \mathrm{~cm} \mathrm{x} 4.6 \mathrm{~mm}, 30 \%$ iso-propanol/hexanes, $1.5 \mathrm{~mL} / \mathrm{min}, 210 \mathrm{~nm}, \mathrm{t}_{\mathrm{R}}=8.5 \mathrm{~min} .[\alpha]_{\mathrm{D}}{ }^{26}-16.0\left(\mathrm{c}=0.25, \mathrm{CH}_{2} \mathrm{Cl}_{2}\right) ;$ IR (neat) 3418 (br, s), 2925 (vs), 2855 (s), 1744 (s), 1652 (w), 1456 (m), 1082 (s); ${ }^{1} \mathrm{H}$ NMR (400 MHz, $\left.\mathrm{CDCl}_{3}\right) \delta 7.16$ (d, $J=$ $1.2 \mathrm{~Hz}, 1 \mathrm{H}), 5.04(\mathrm{dq}, J=6.6,1.4 \mathrm{~Hz}, 1 \mathrm{H}), 3.89-3.79(\mathrm{~m}, 3 \mathrm{H}), 3.78$ (q, $J=7.0 \mathrm{~Hz}, 1 \mathrm{H}), 3.49-3.36$ (m, 2H), 3.29-3.22 (m, 1H), 3.16-3.10 (m, 1H), $3.03(\mathrm{dt}, J=8.8,2.3 \mathrm{~Hz}, 1 \mathrm{H}), 2.83$ (d, $J=2.8 \mathrm{~Hz}$, $1 \mathrm{H}), 2.69(\mathrm{~d}, J=3.1 \mathrm{~Hz}, 1 \mathrm{H}), 2.51\left(\mathrm{dt}, \mathrm{A}\right.$ of $\left.\mathrm{ABX}_{2}, J_{A B}=15.2, J_{A X}=1.6 \mathrm{~Hz}, 1 \mathrm{H}\right), 2.38(\mathrm{dd}, \mathrm{B}$ of $\left.\mathrm{ABX}_{2}, J_{A B}=15.0, J_{B X}=8.3 \mathrm{~Hz}, 1 \mathrm{H}\right), 2.25(\mathrm{~d}, J=5.2 \mathrm{~Hz}, 1 \mathrm{H}), 2.12-2.04(\mathrm{~m}, 1 \mathrm{H}), 2.03-1.91(\mathrm{~m}$, $2 \mathrm{H}), 1.85-1.77(\mathrm{~m}, 1 \mathrm{H}), 1.70-1.23(\mathrm{~m}, 40 \mathrm{H}), 1.41(\mathrm{~d}, J=6.7 \mathrm{~Hz}, 3 \mathrm{H}), 0.86(\mathrm{t}, J=6.8 \mathrm{~Hz}, 3 \mathrm{H}) ;{ }^{13} \mathrm{C}$ NMR (100 MHz, $\mathrm{CDCl}_{3}$ ) 174.82 (e), 152.00 (o), 131.30 (e), 82.15 (o), 82.06 (o), 80.28 (o), 79.47 (o), 78.16 (o), 73.93 (o), 73.63 (o), 70.68 (o), 70.09 (o), 37.52 (e), 35.73 (e), 33.48 (e), 32.75 (e), 32.56 (e), 32.12 (e), 32.06 (e), 29.87 (e), 29.78 (e), 29.69 (e), 29.60 (e), 29.55 (e), 29.48 (e), 28.90 (e), 28.83 (e), 28.49 (e), 27.05 (e), 26.31 (e), 25.67 (e), 25.63 (e), 22.82 (e), 19.24 (o), 14.27 (o); HRMS (FAB, M+Na ${ }^{+}$calcd for $\mathrm{C}_{37} \mathrm{H}_{66} \mathrm{NaO}_{8} 661.4655$, found 661.4652. 


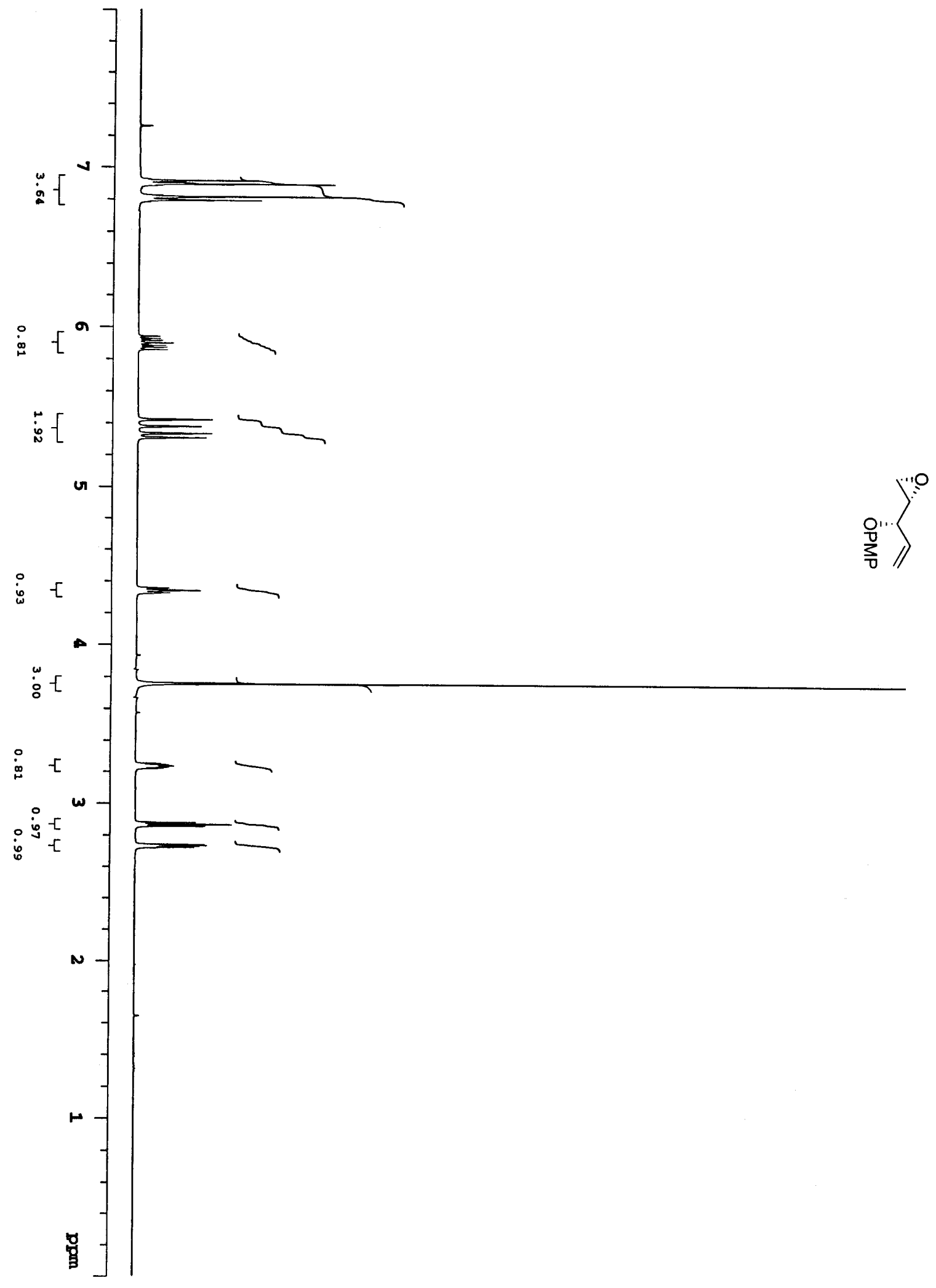



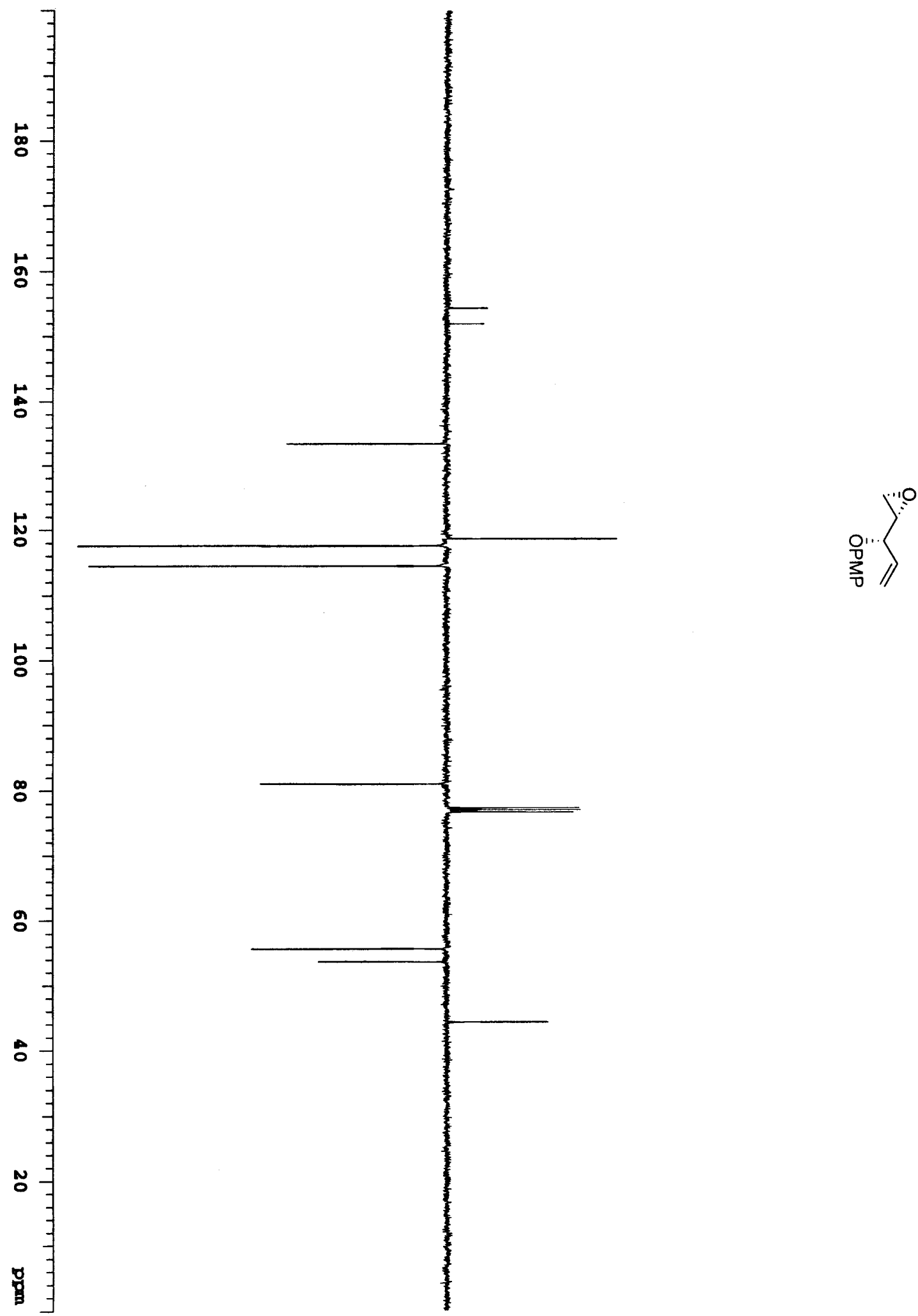


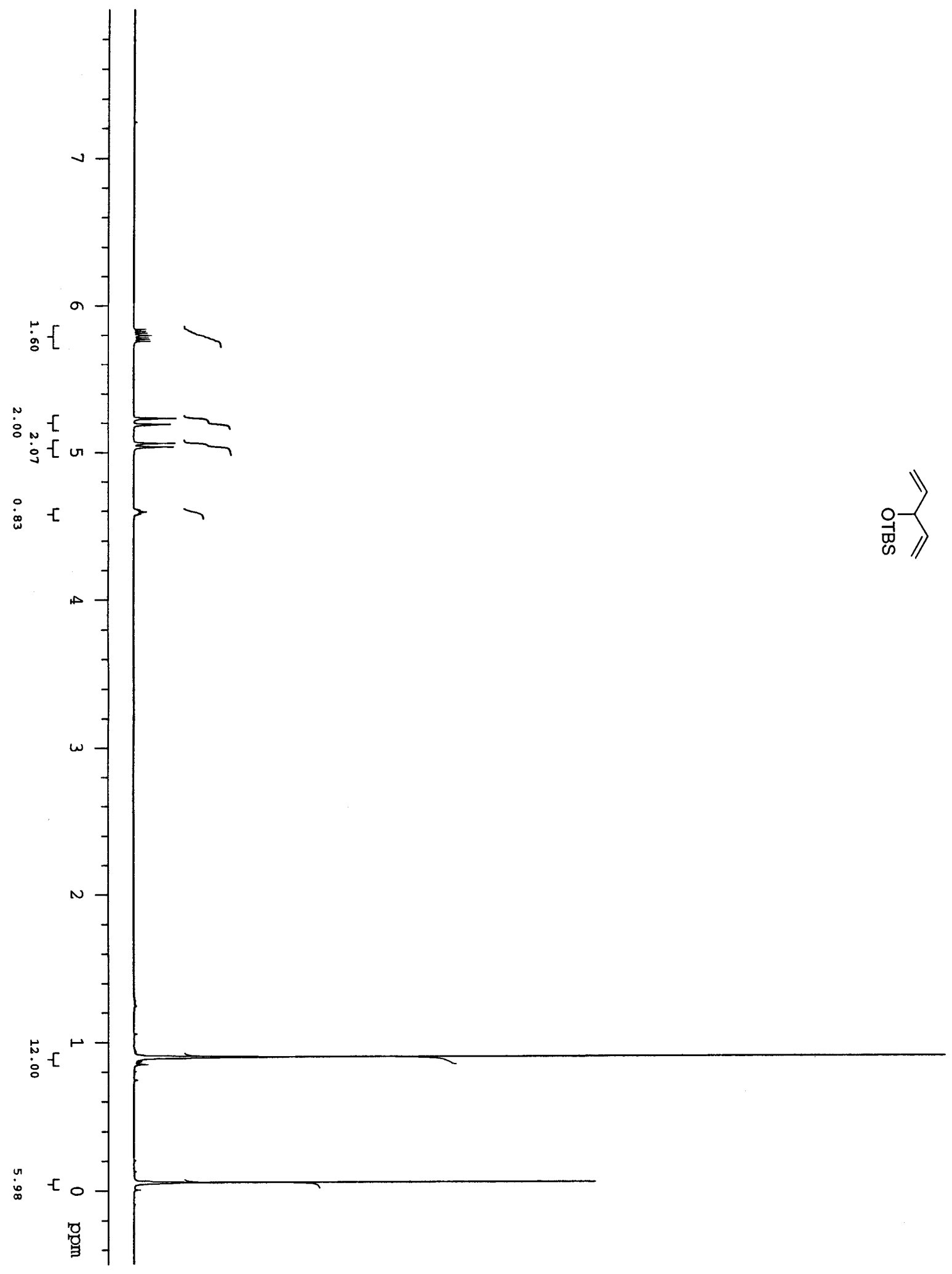




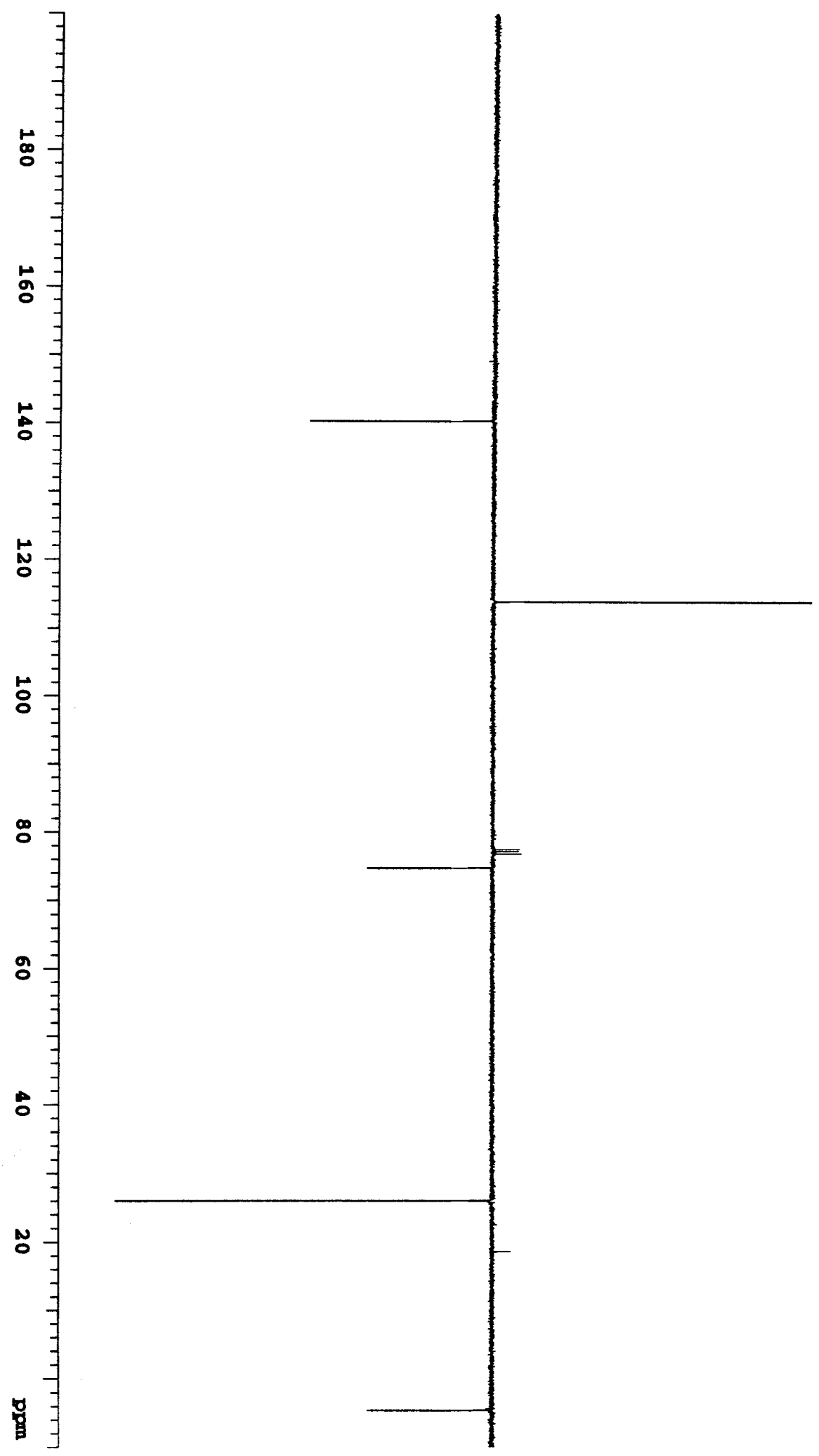

式 


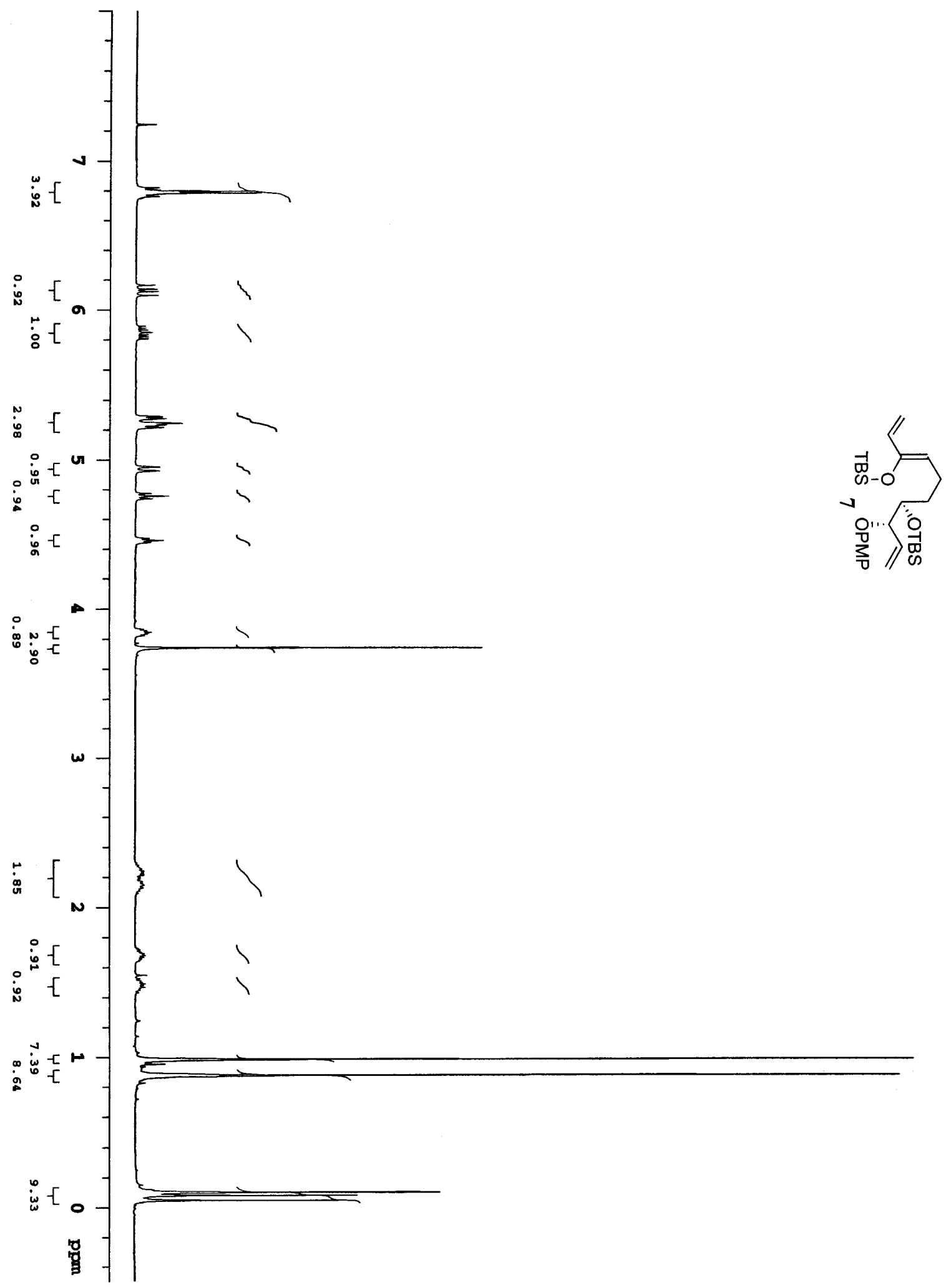



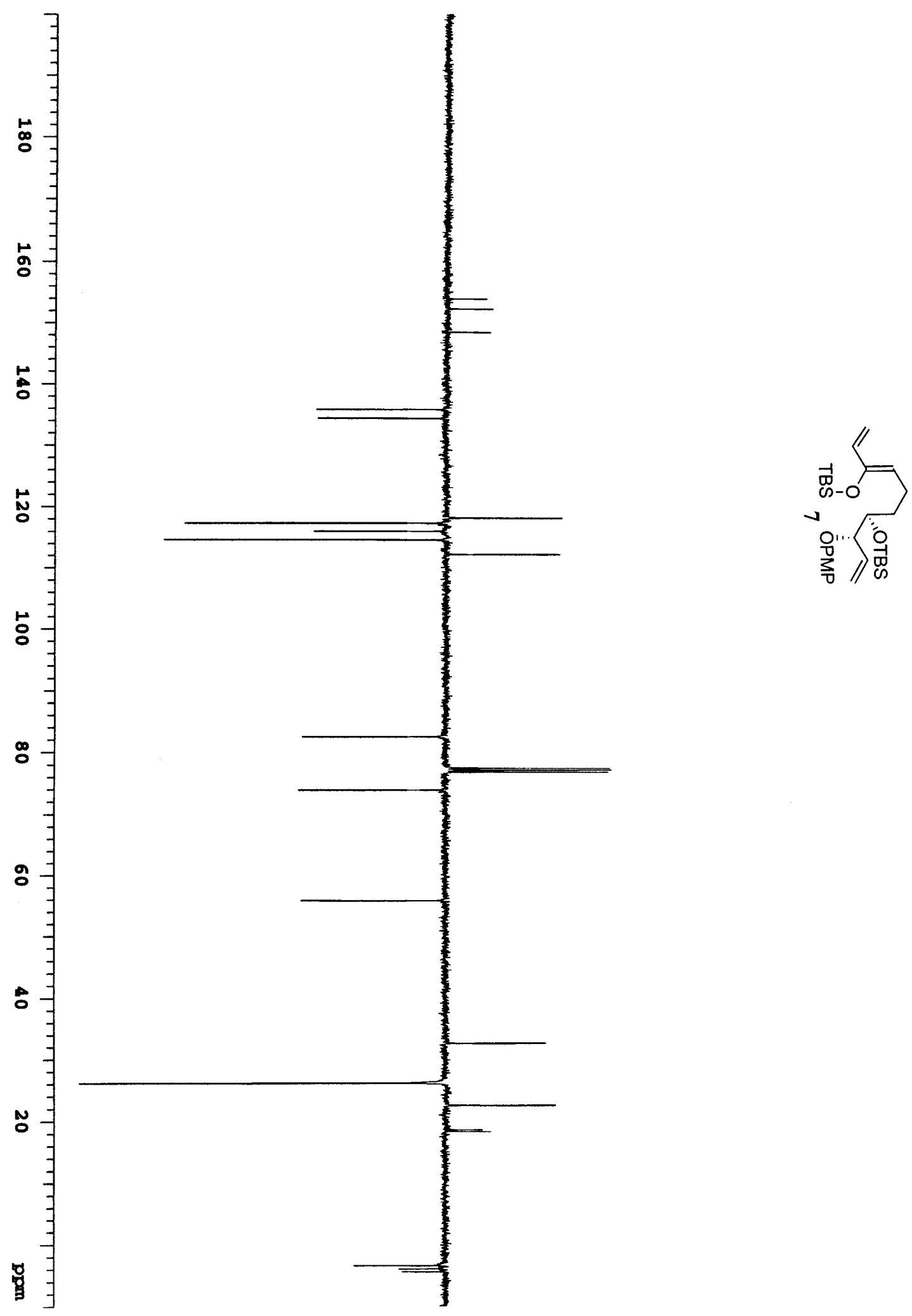


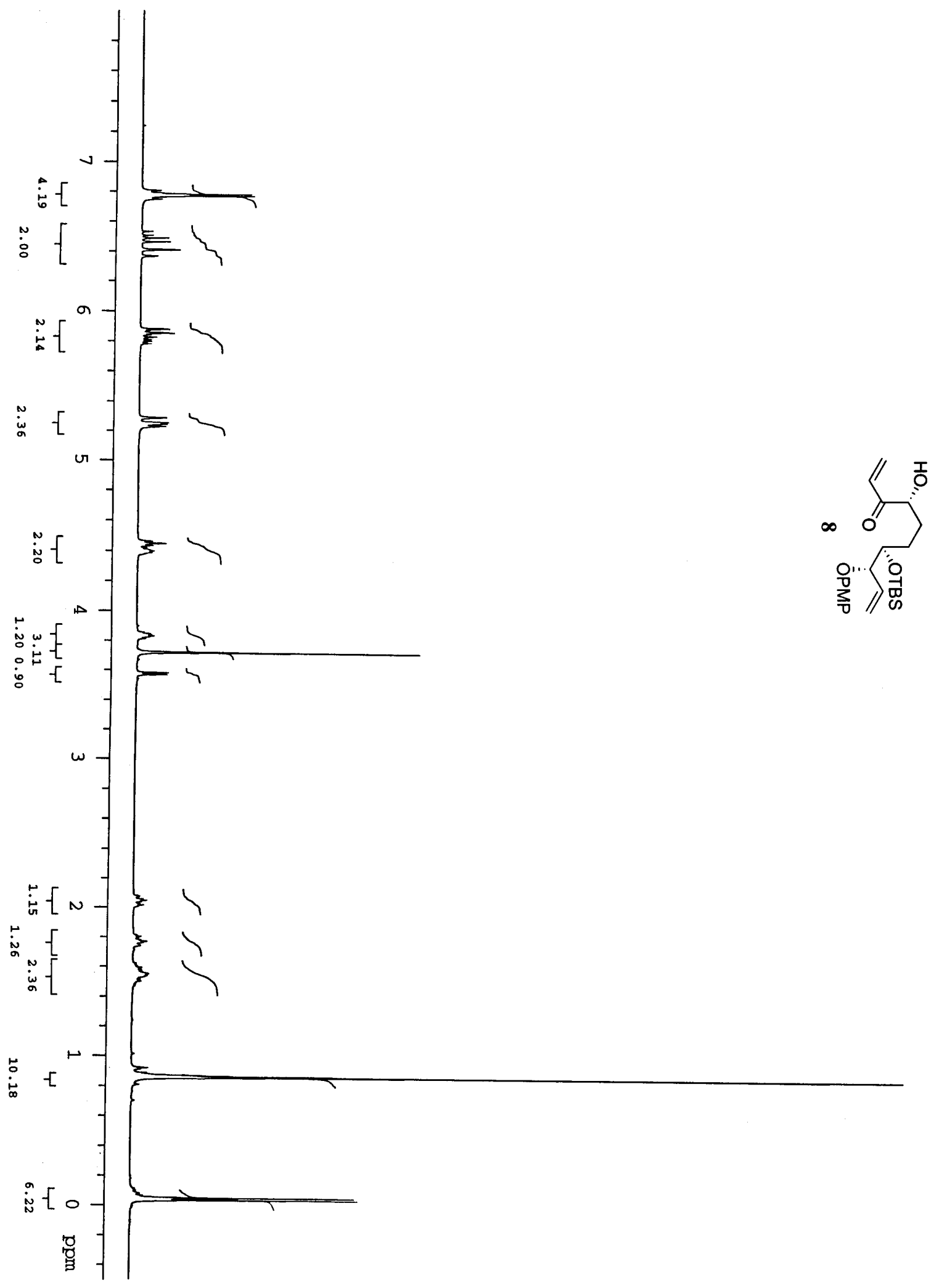



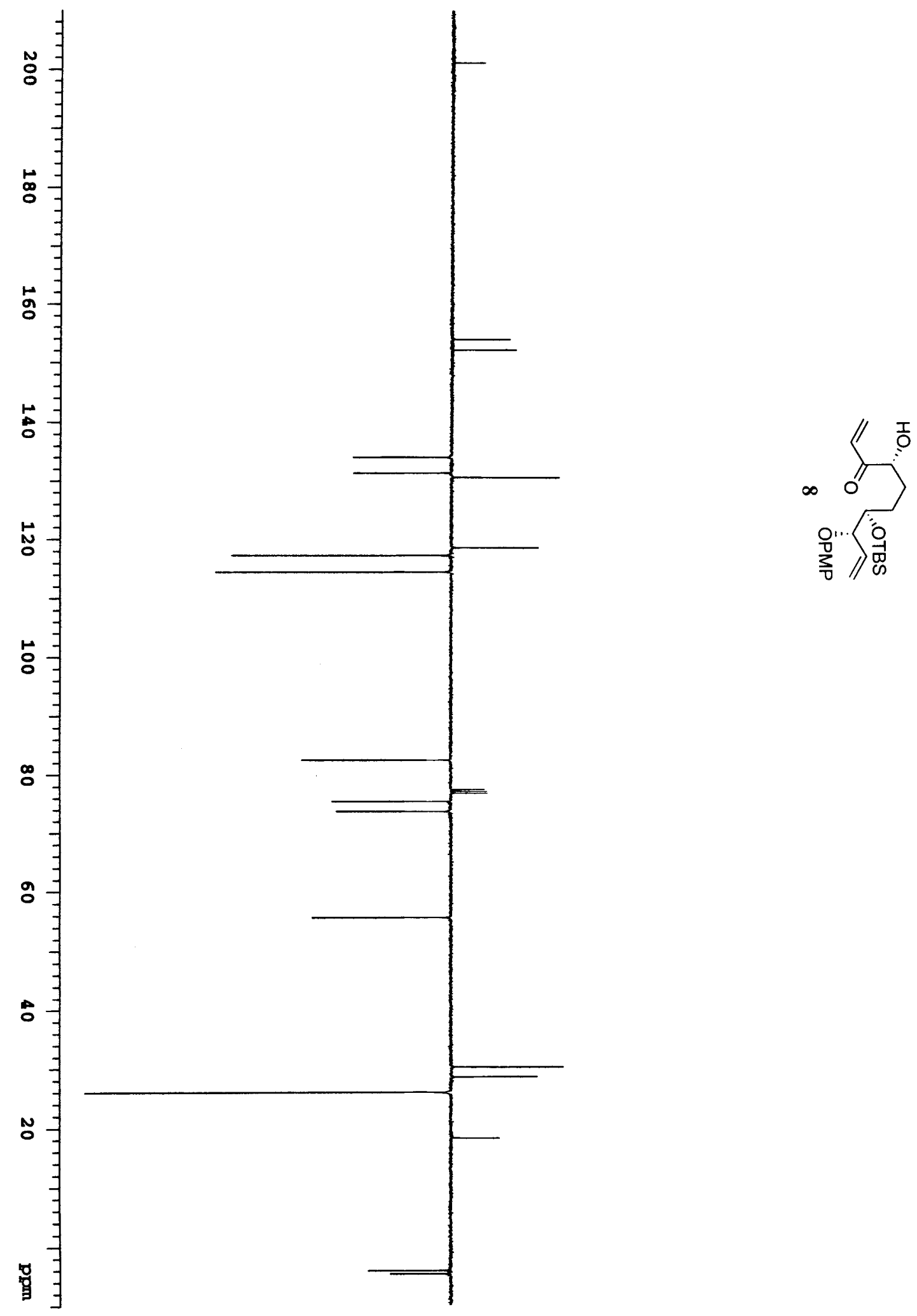


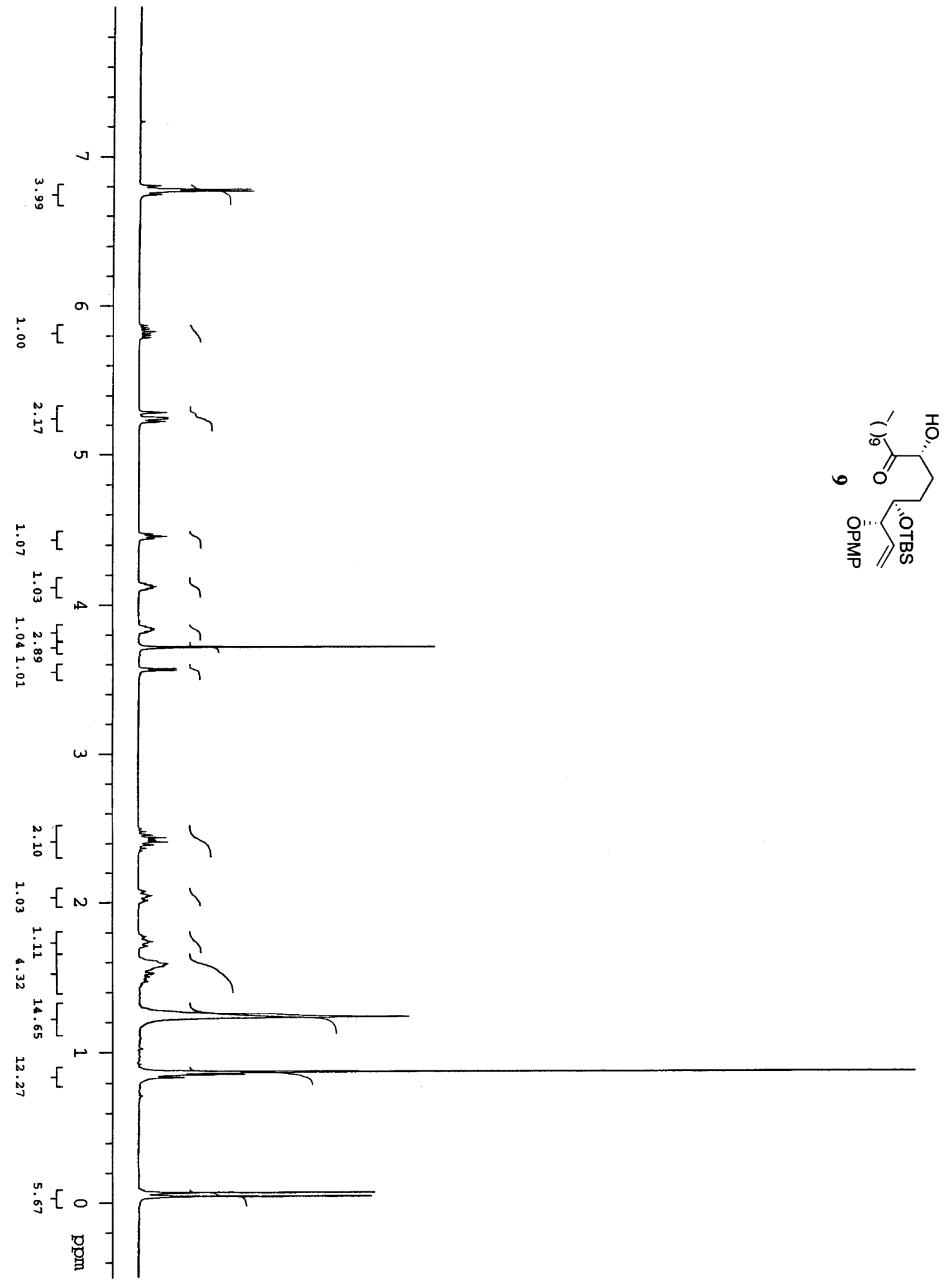



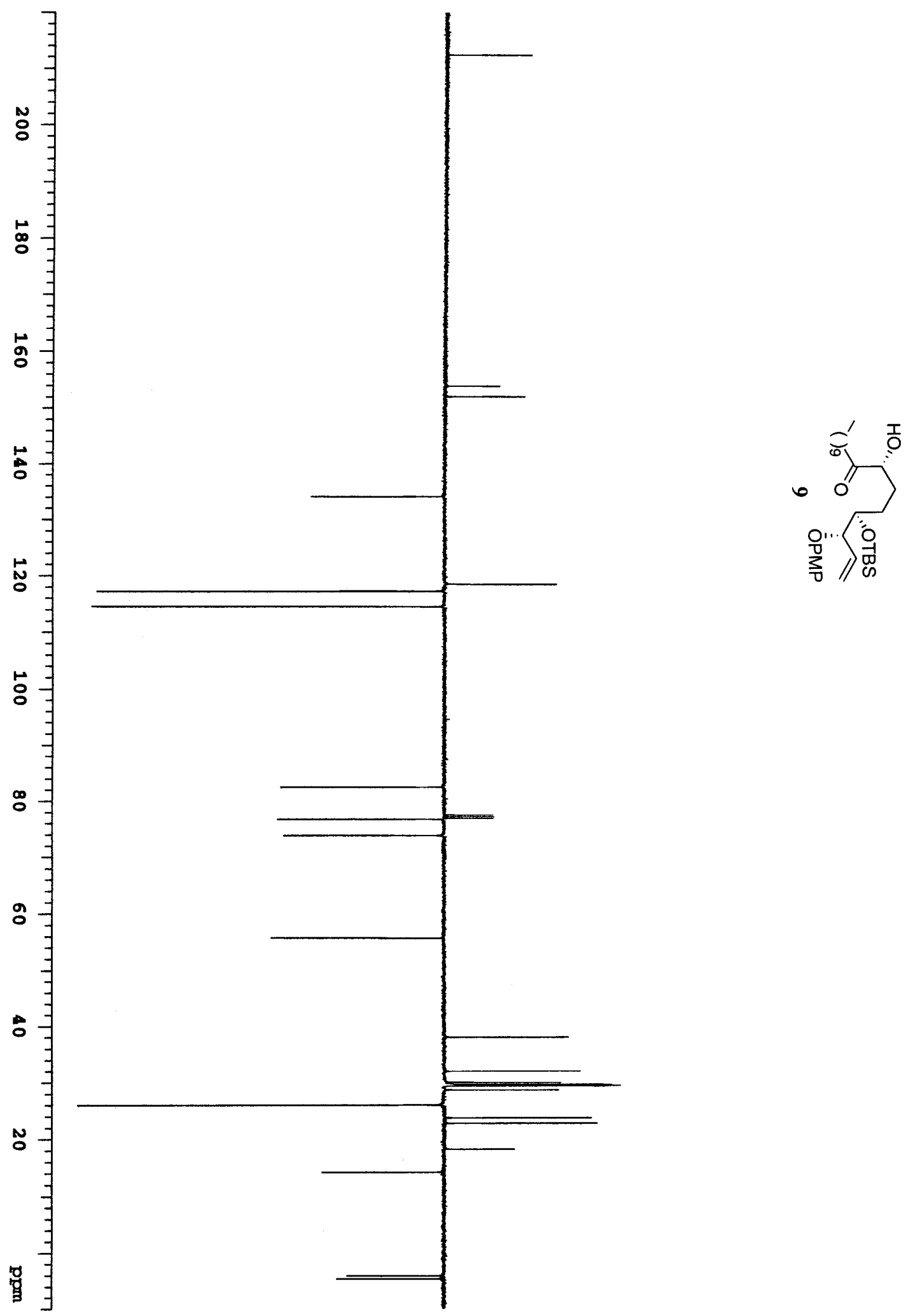


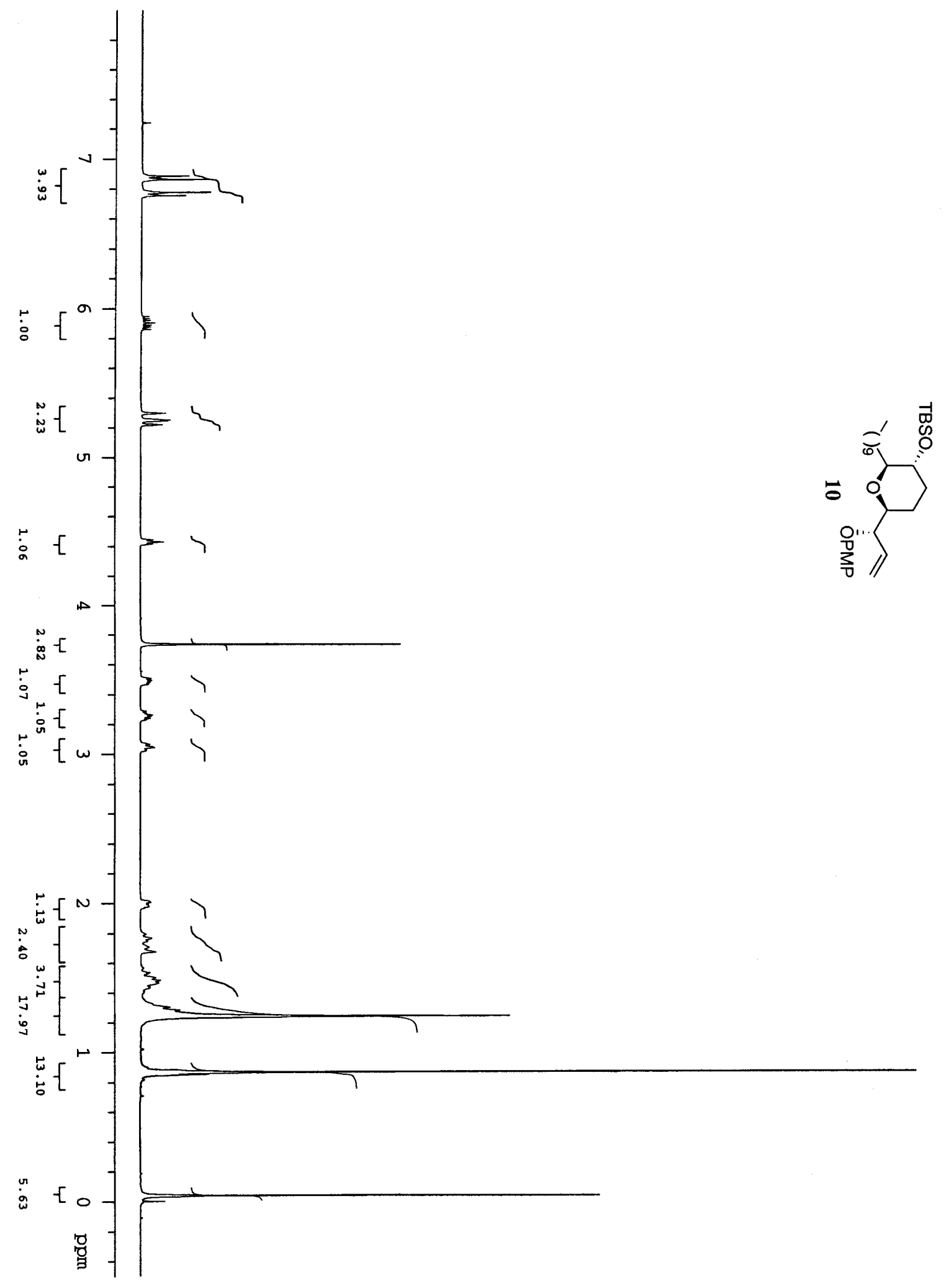



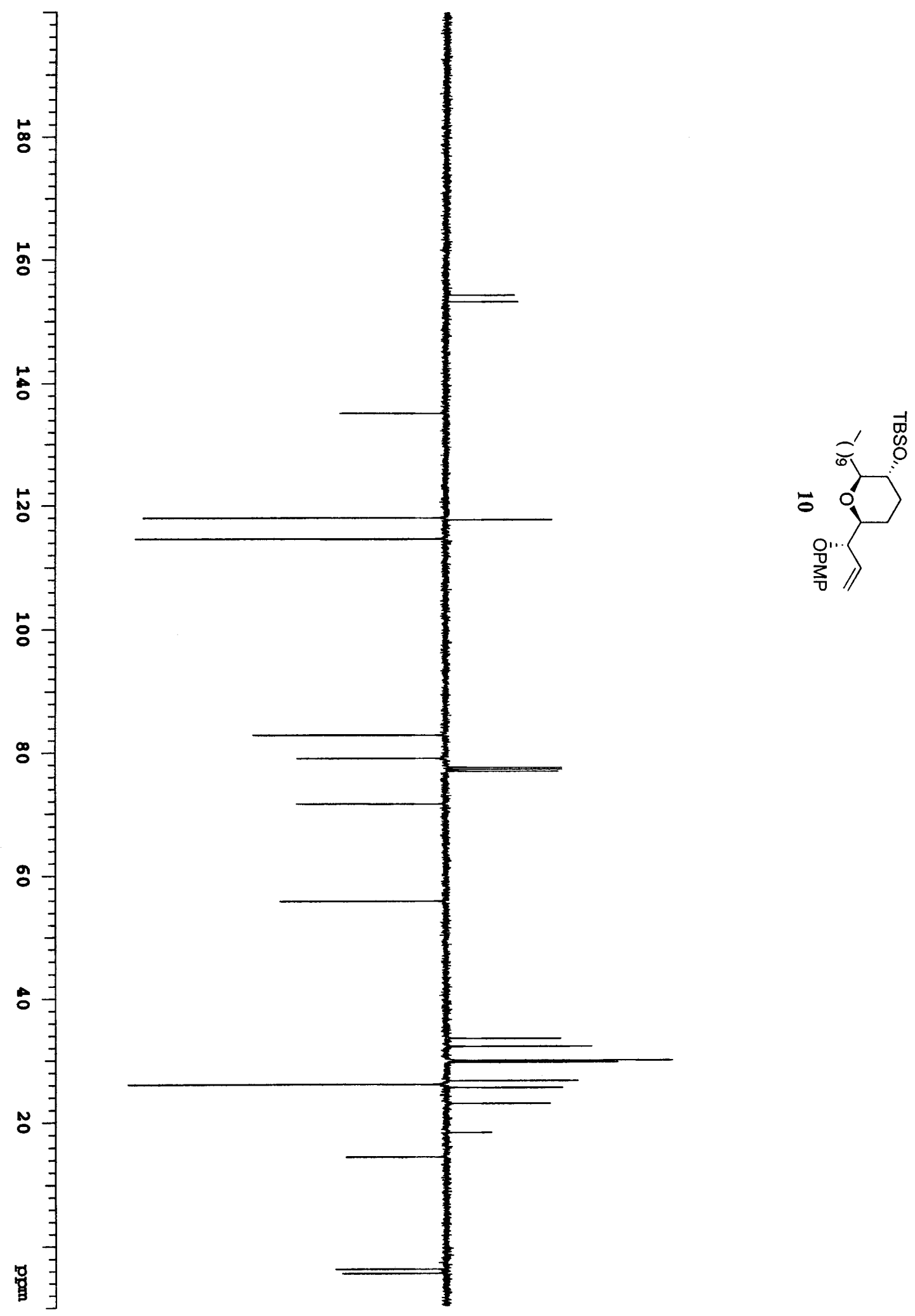


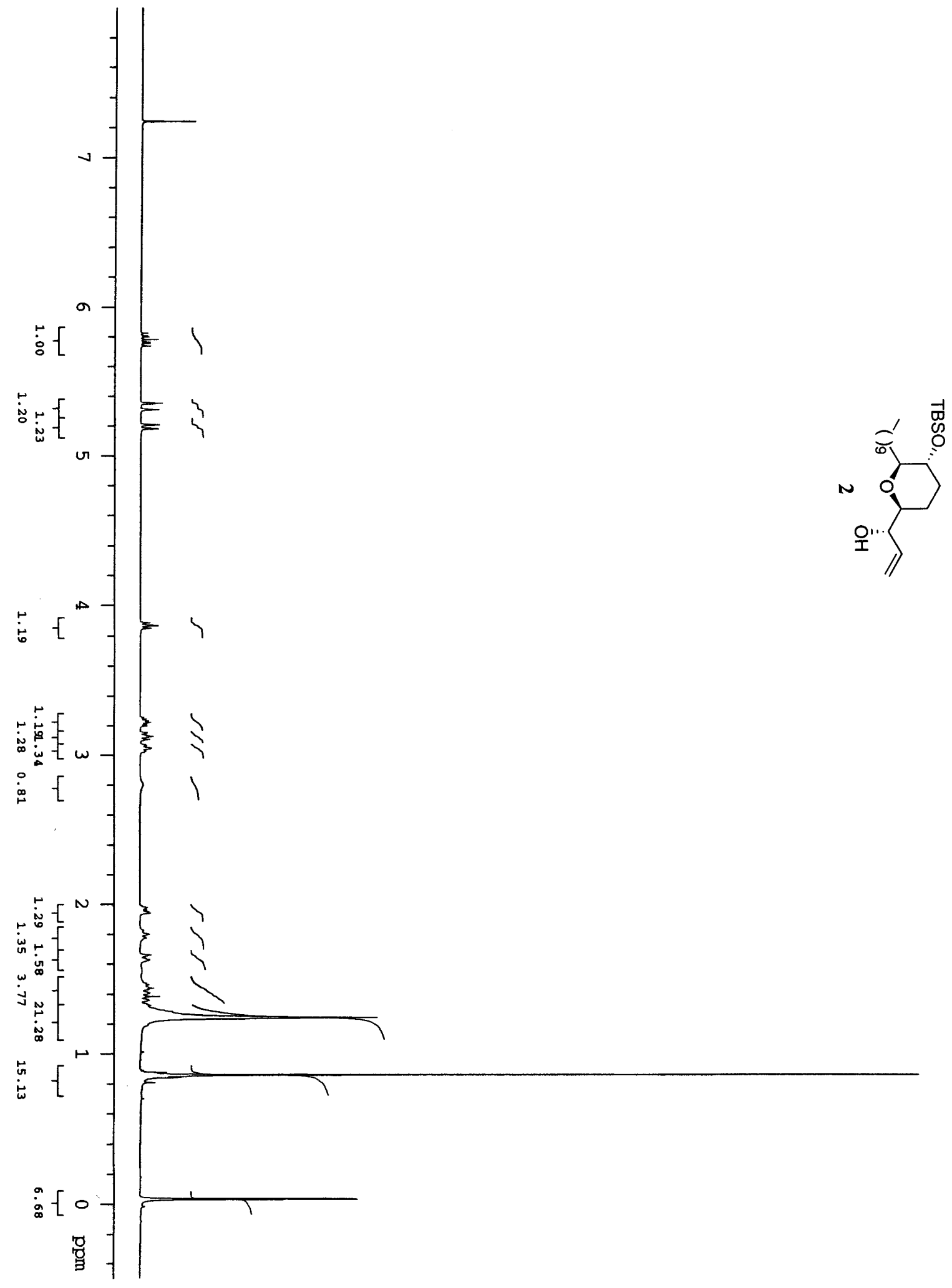




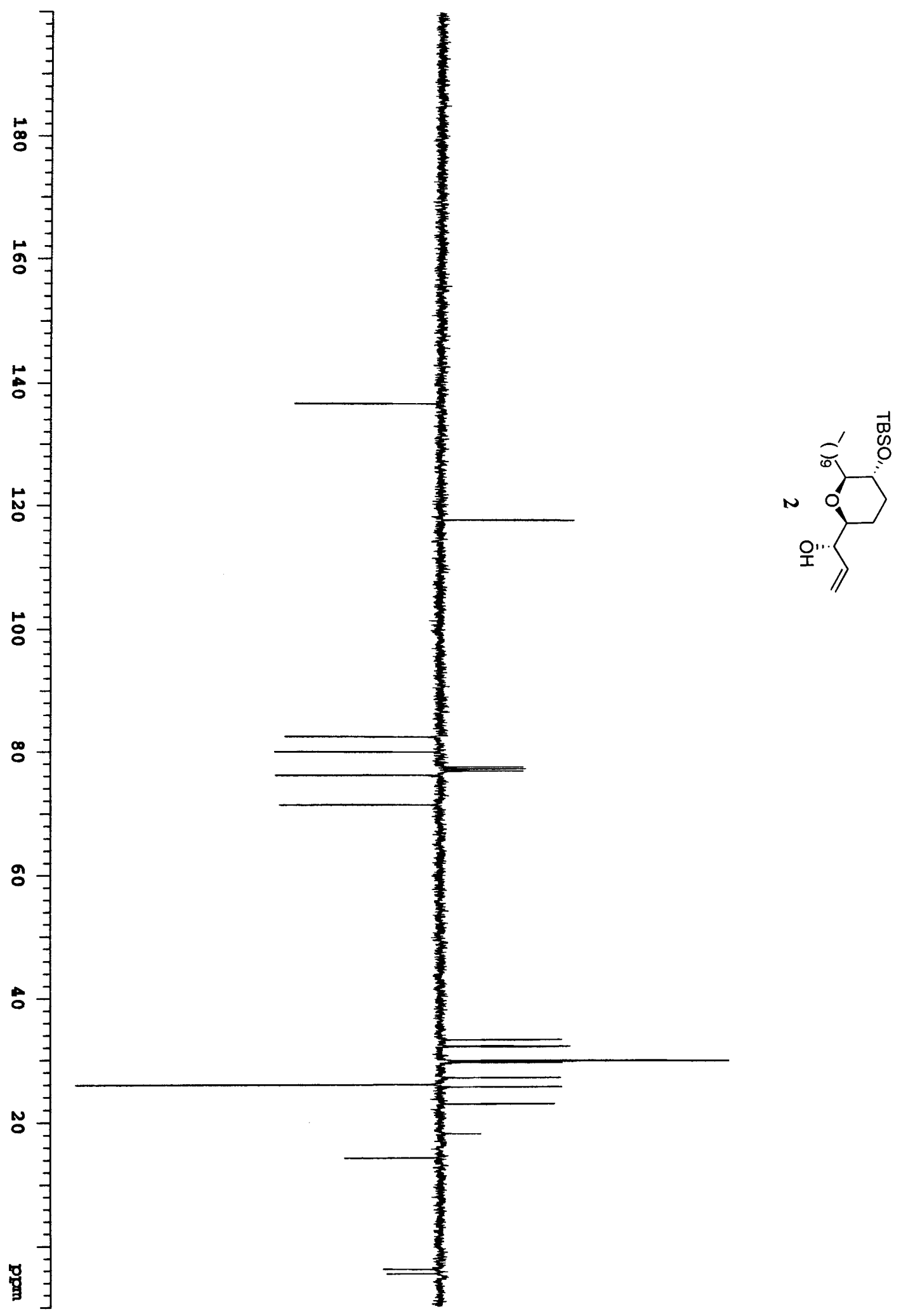




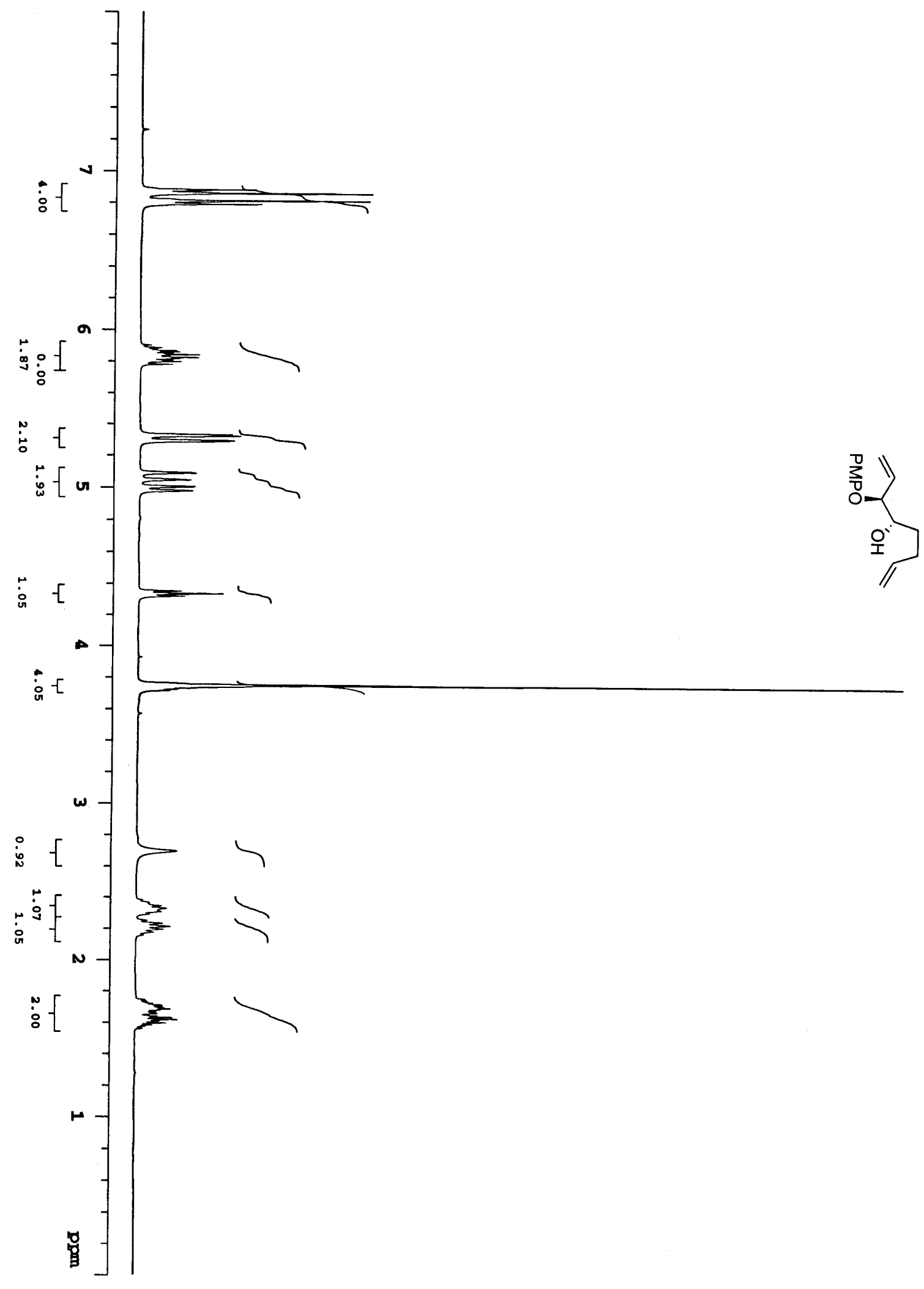



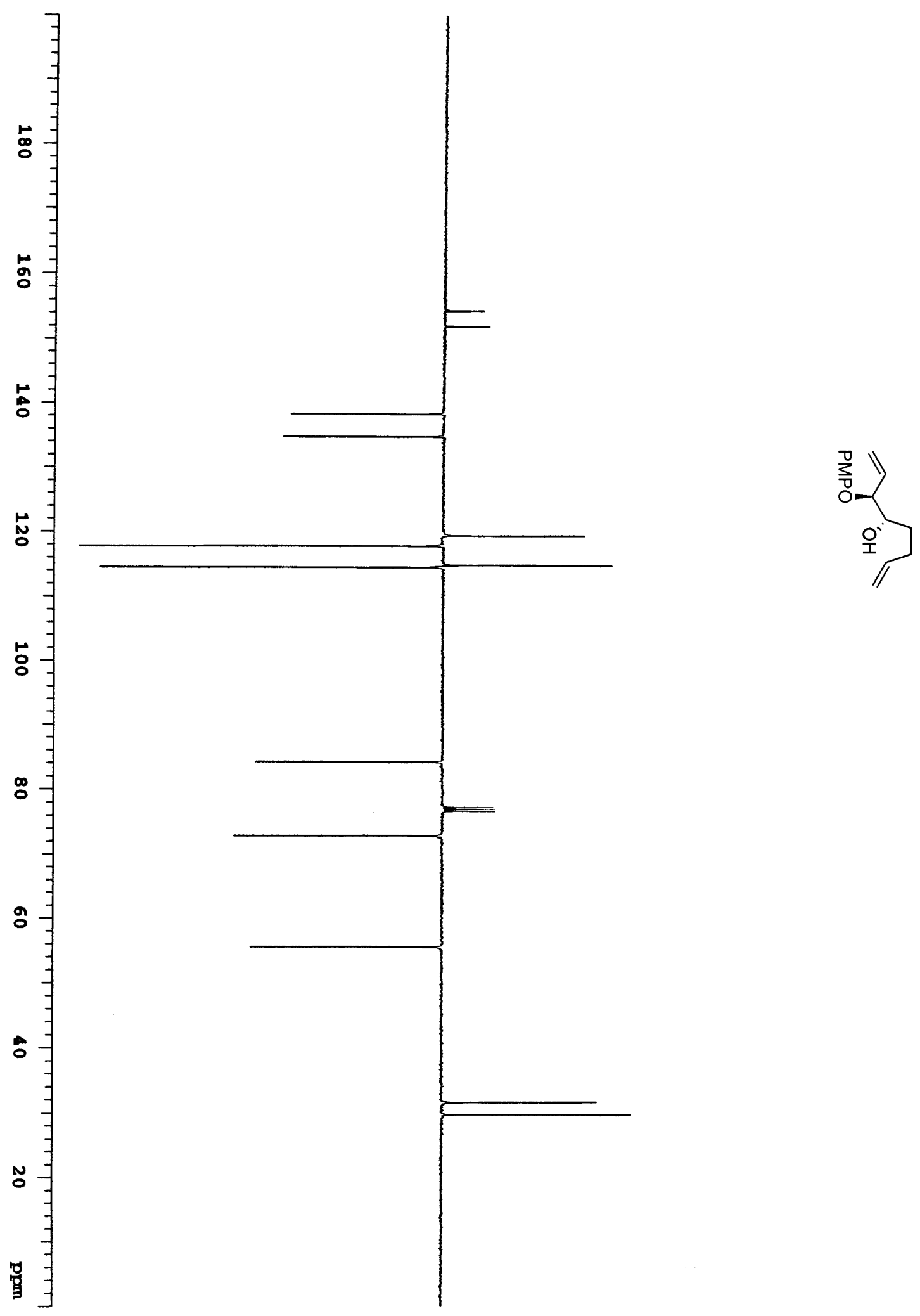


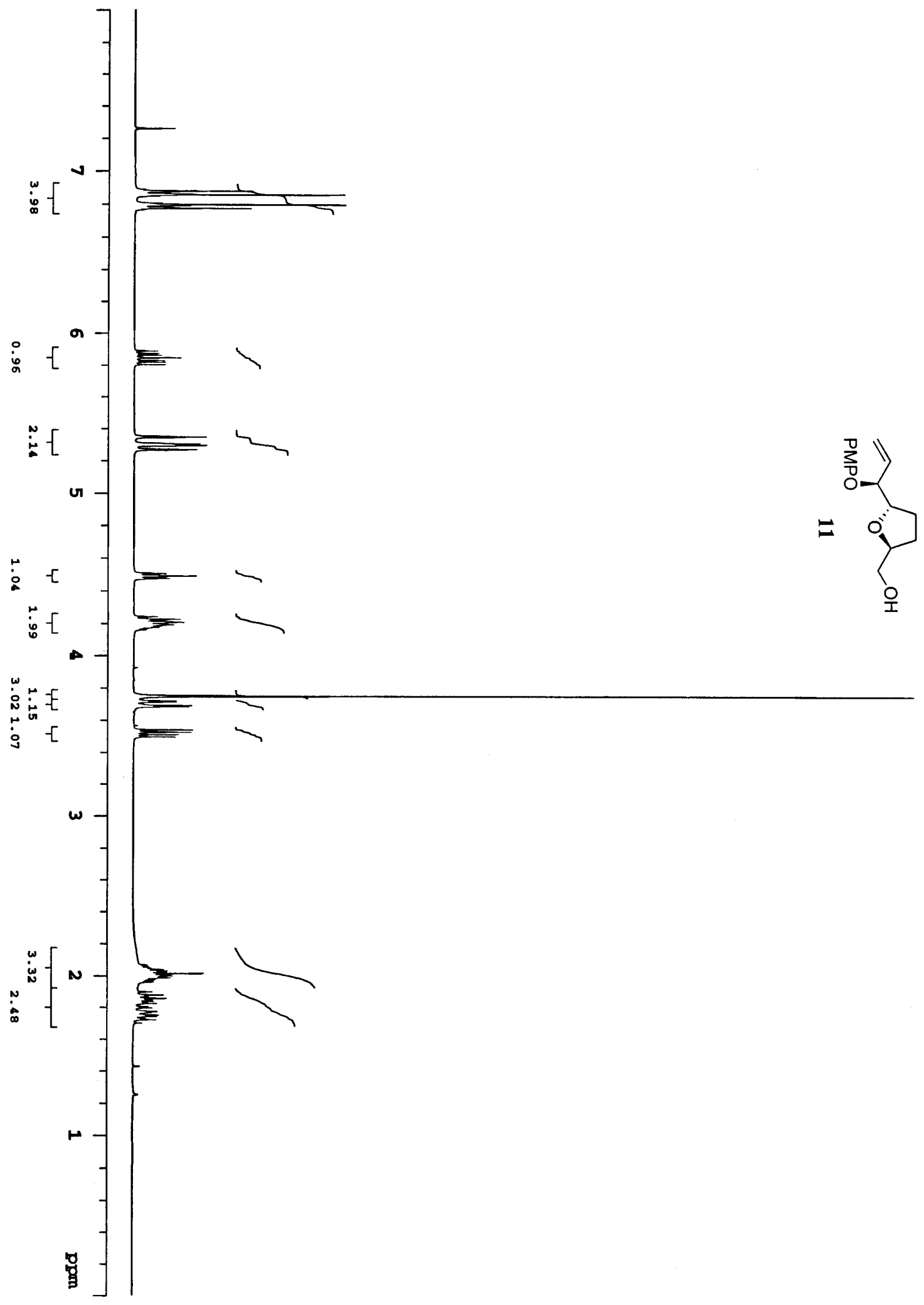




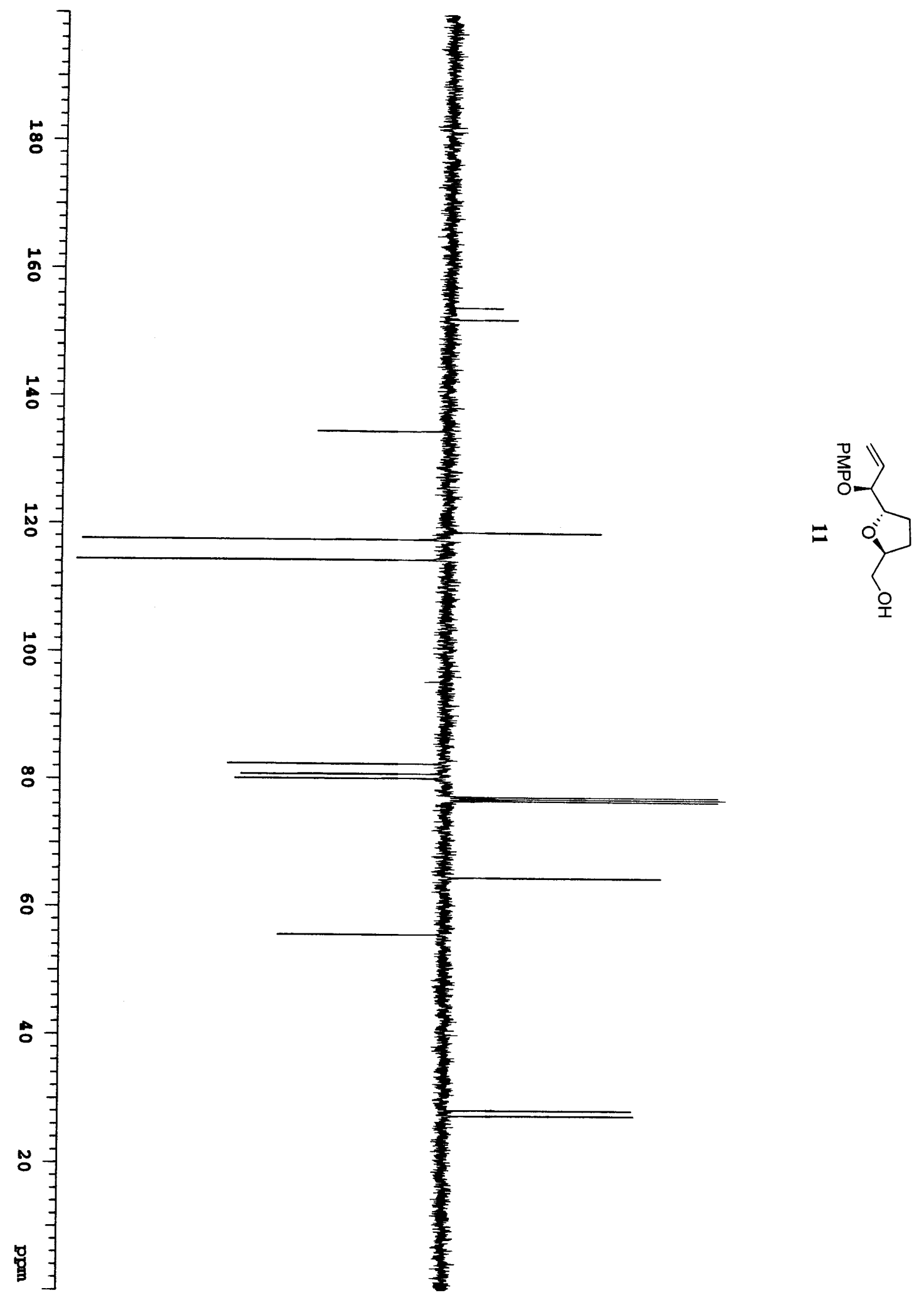




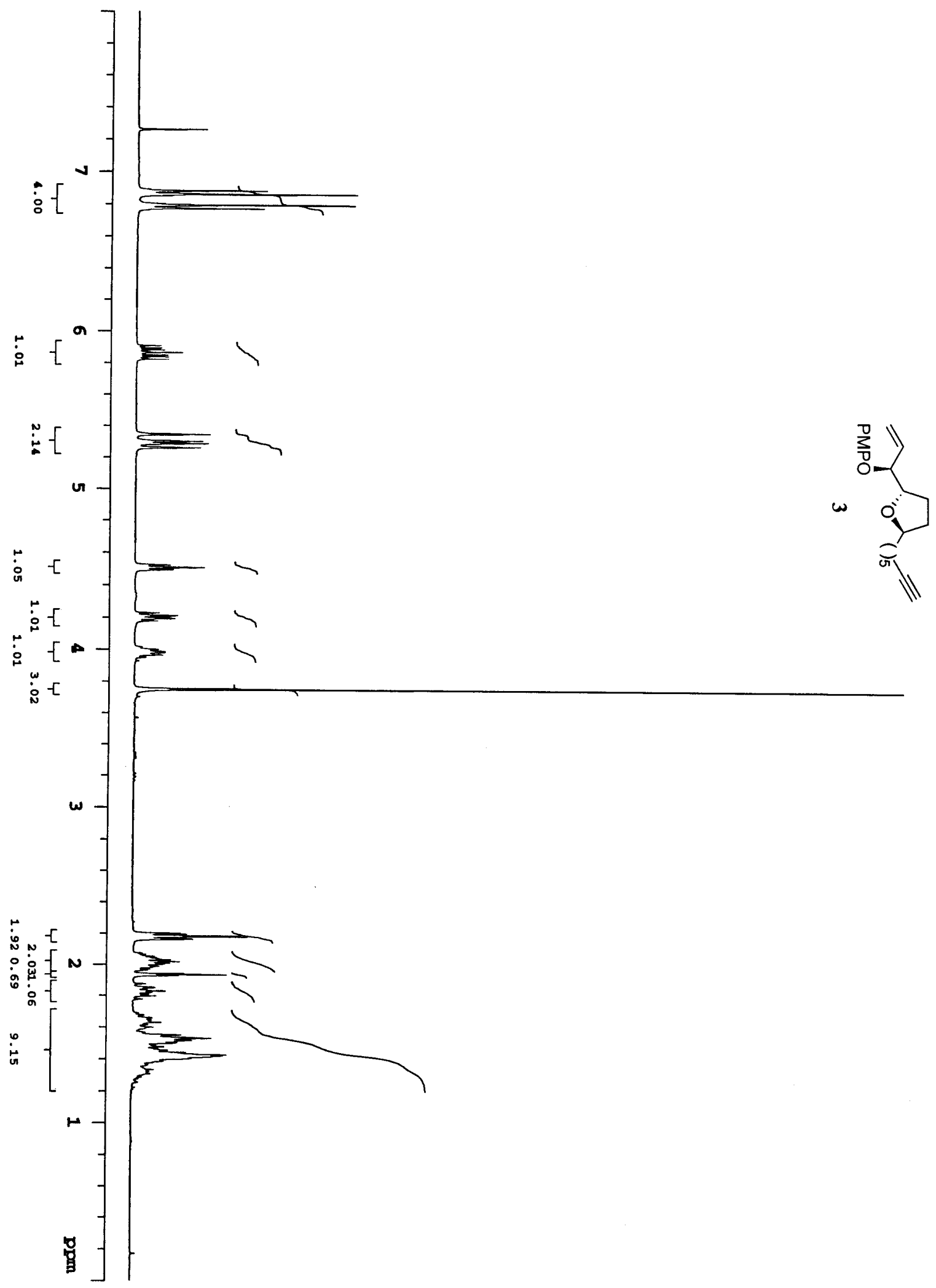



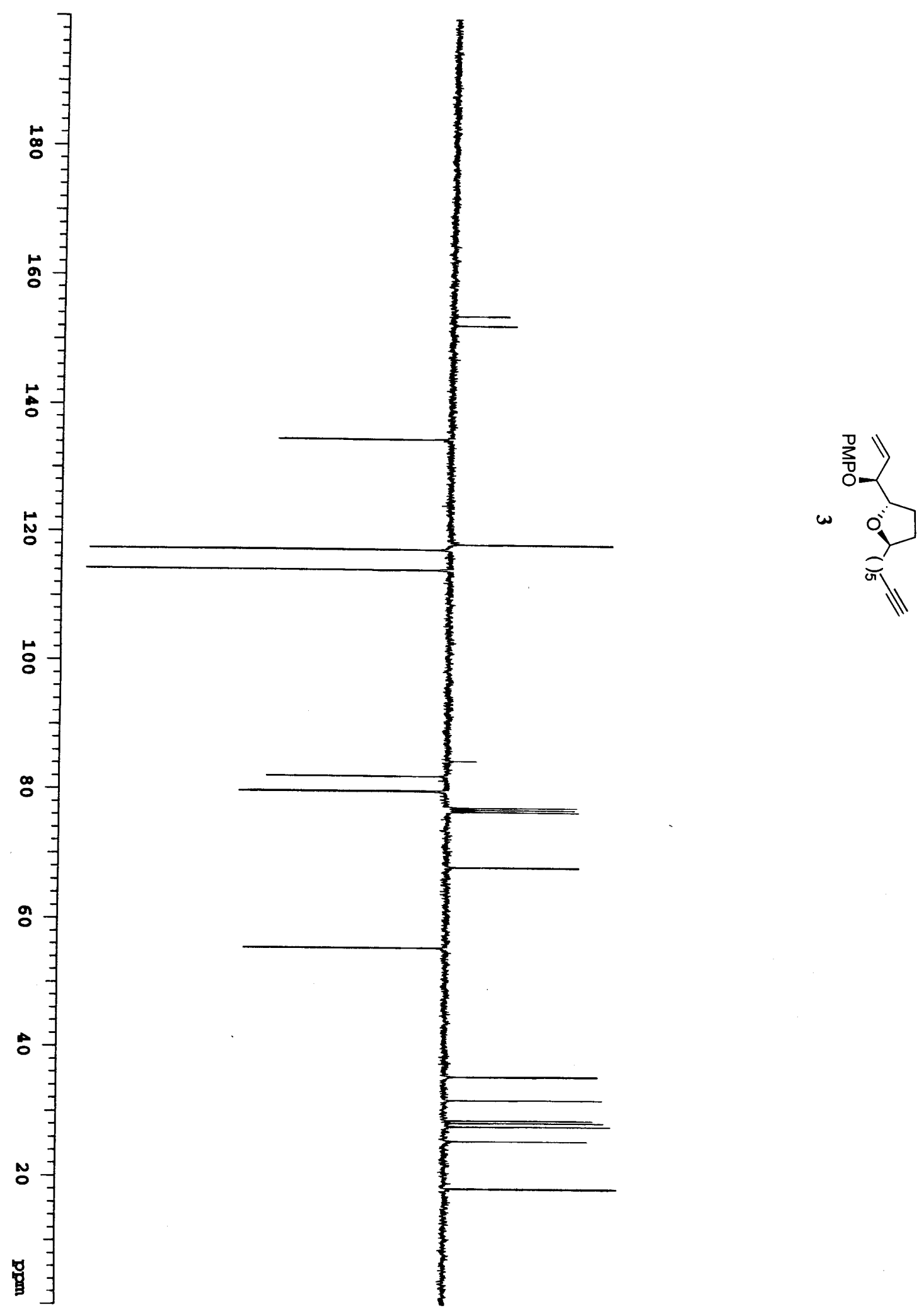


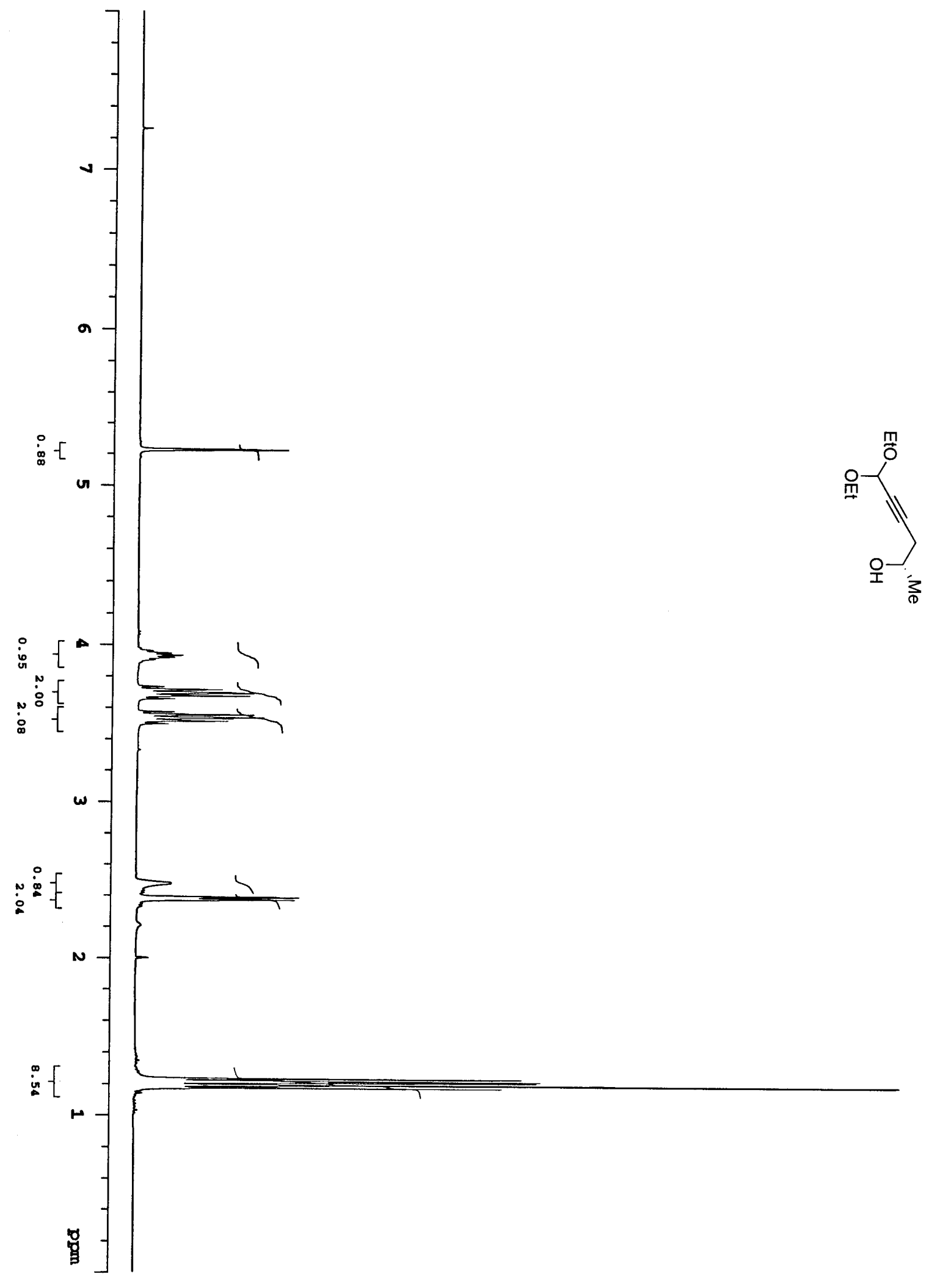




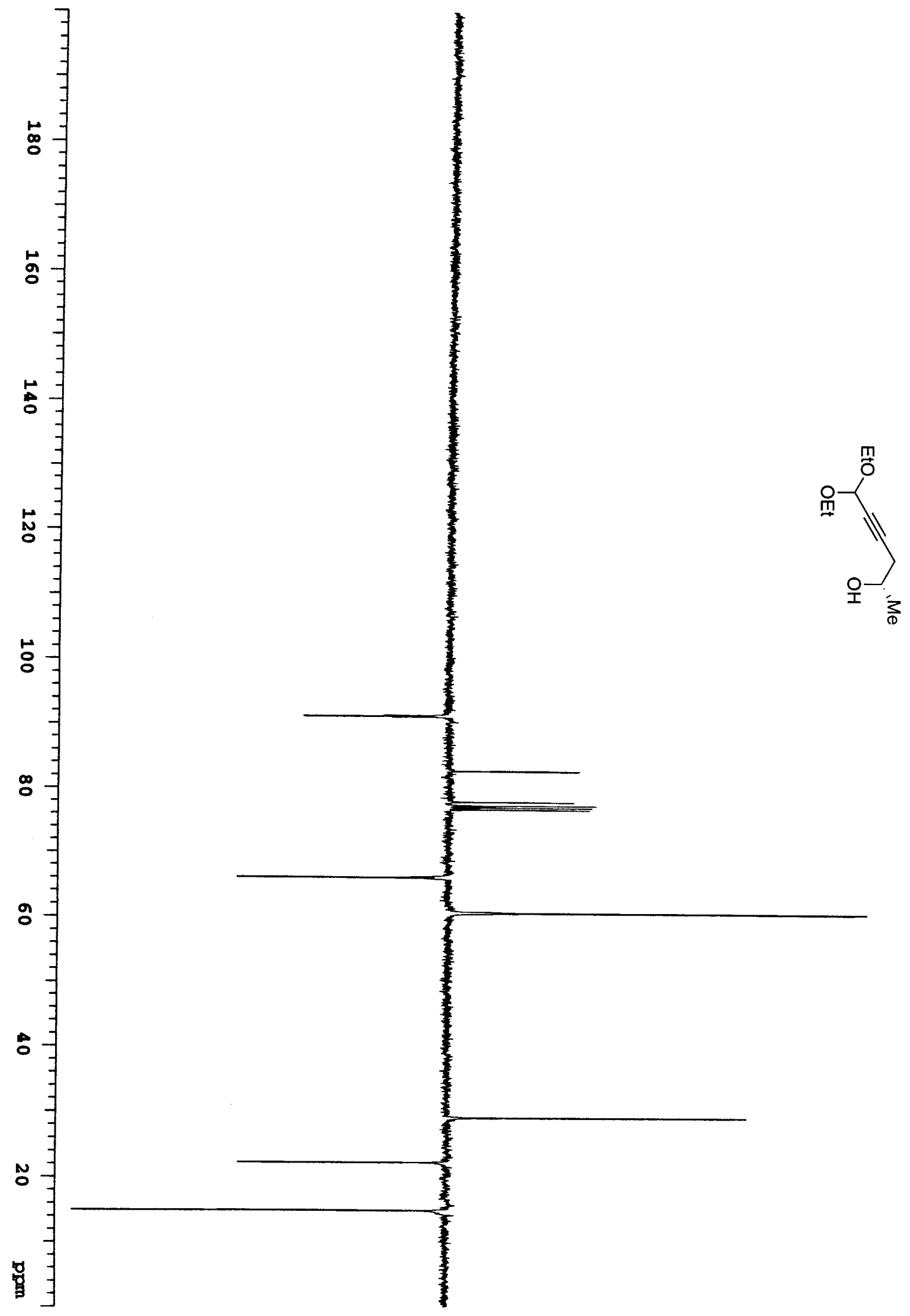




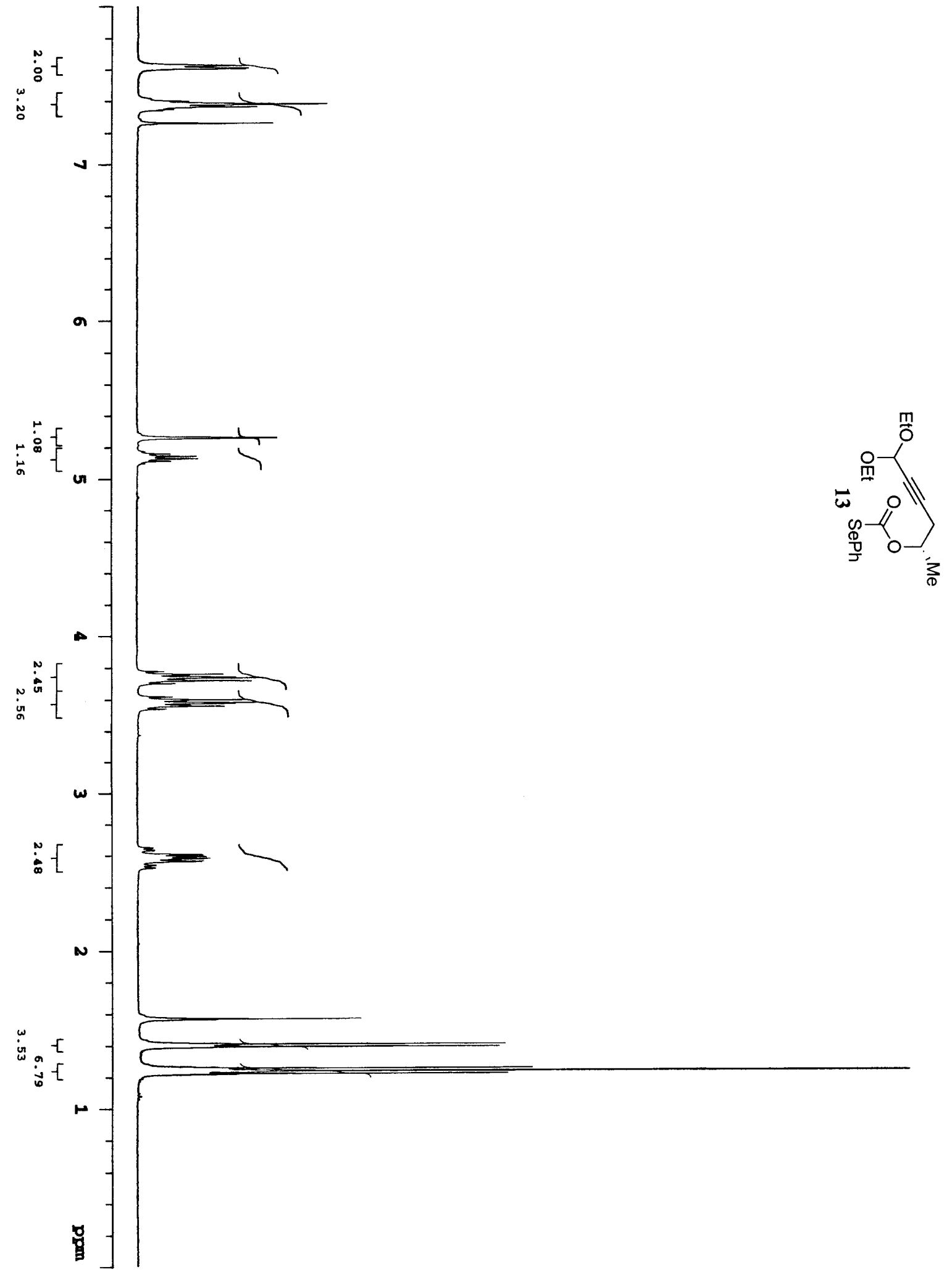




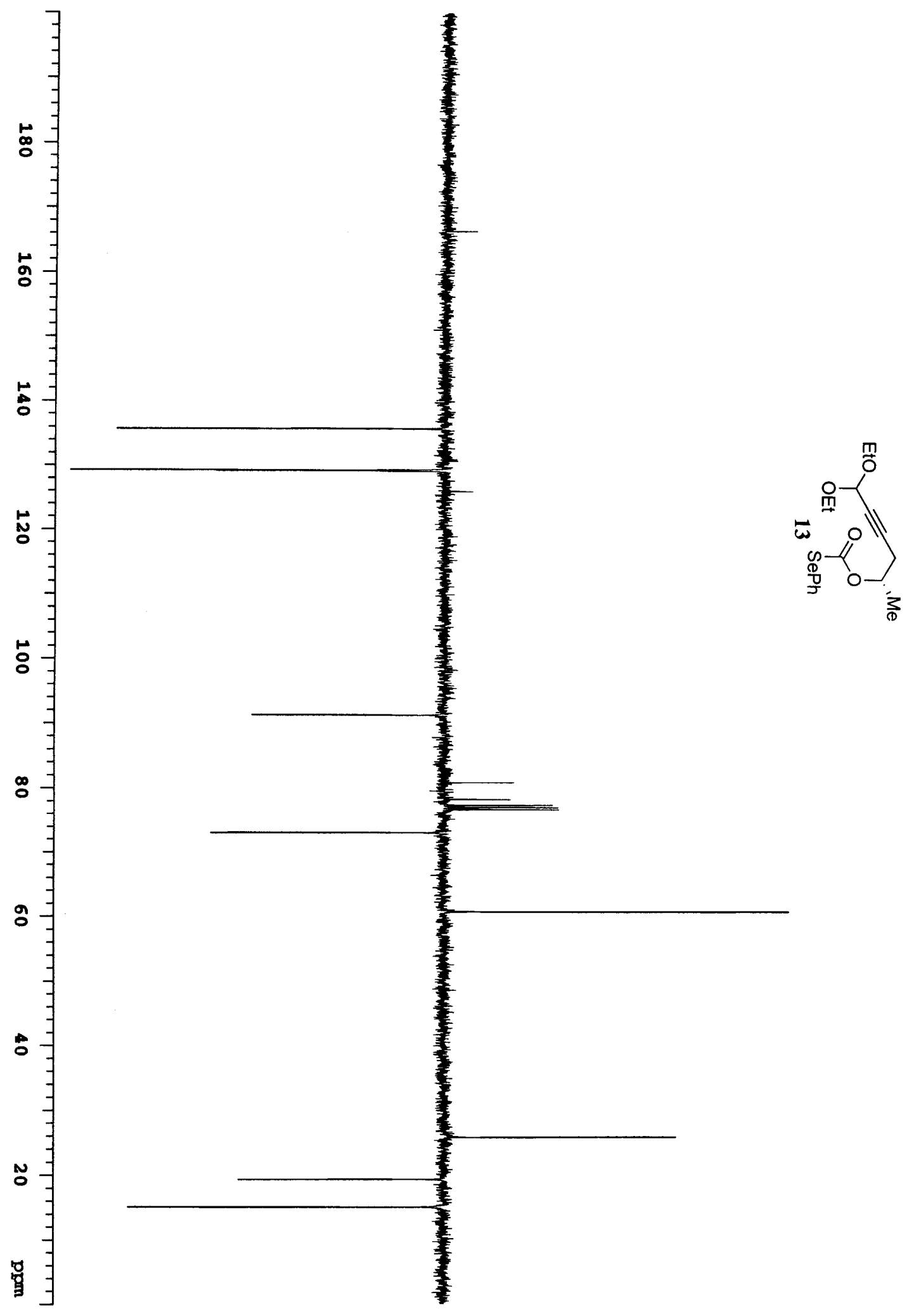




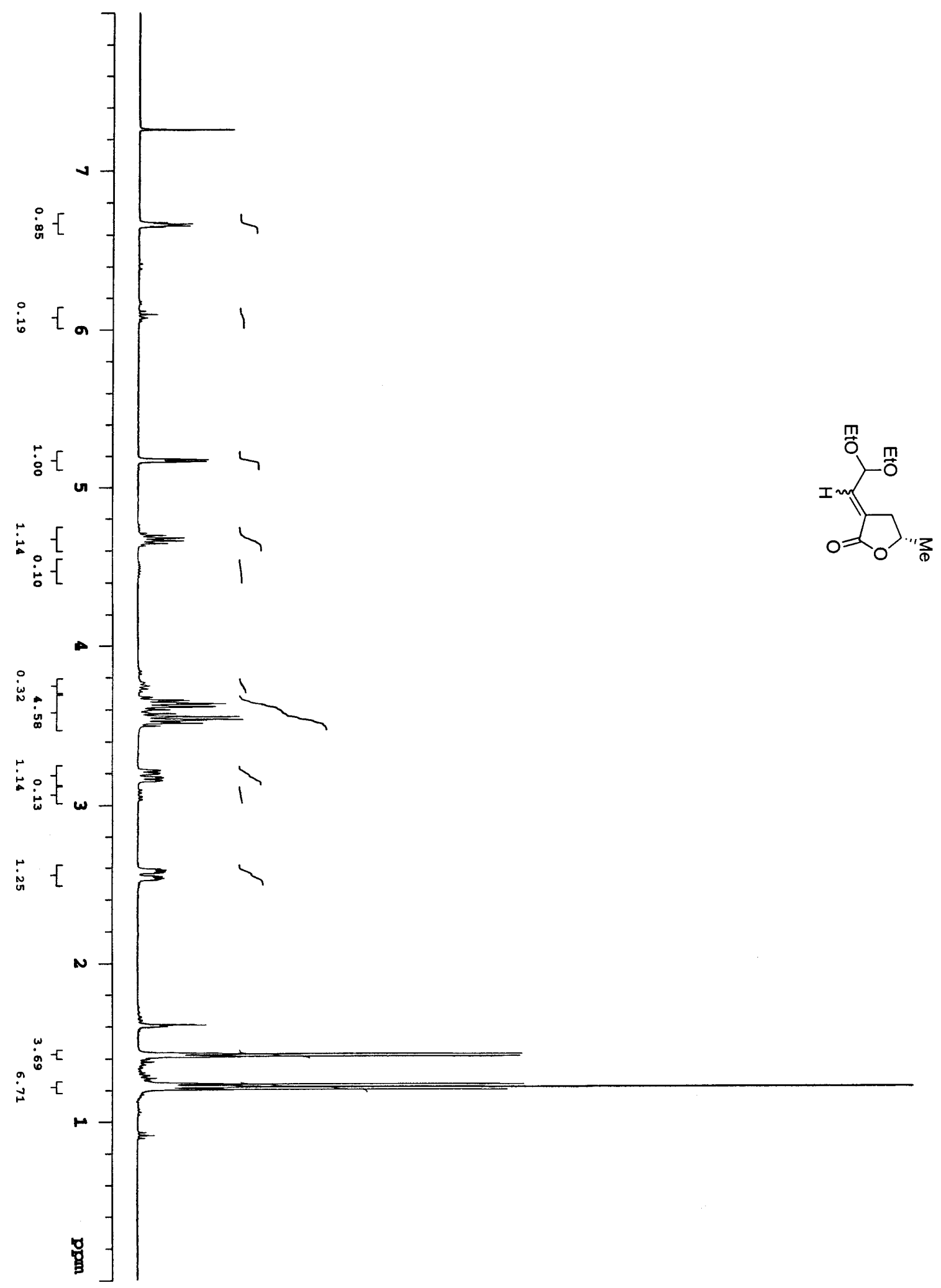



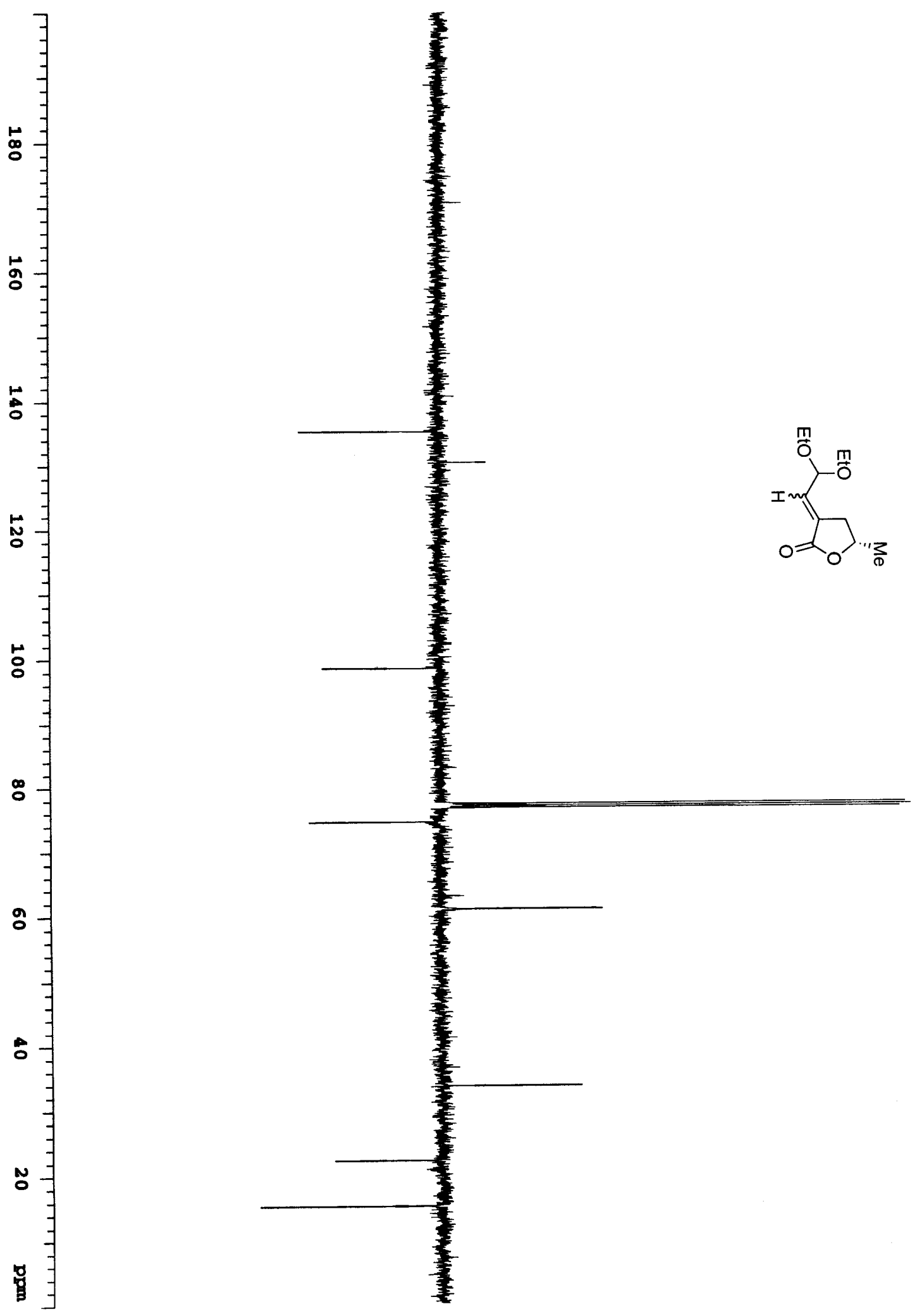


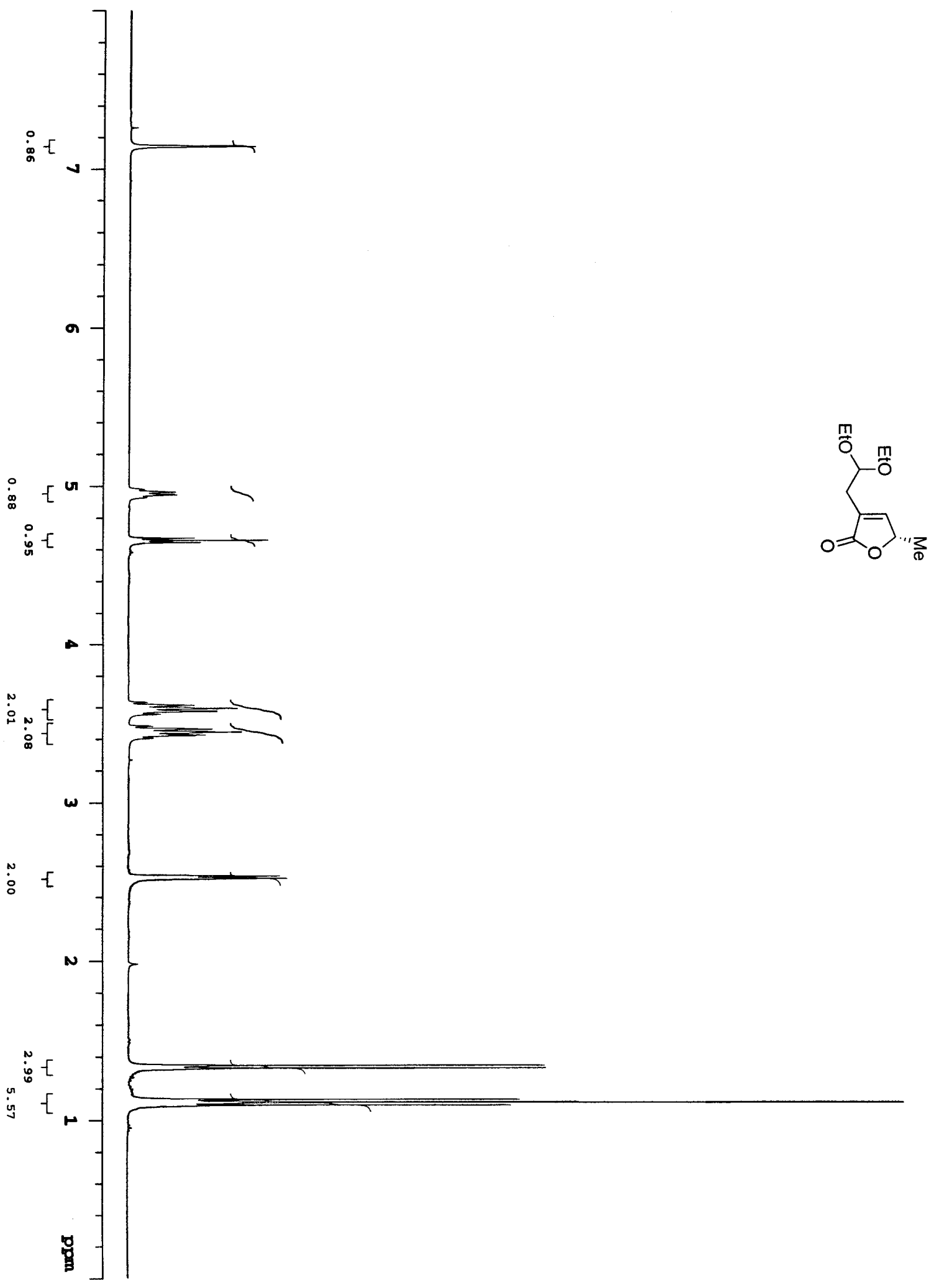




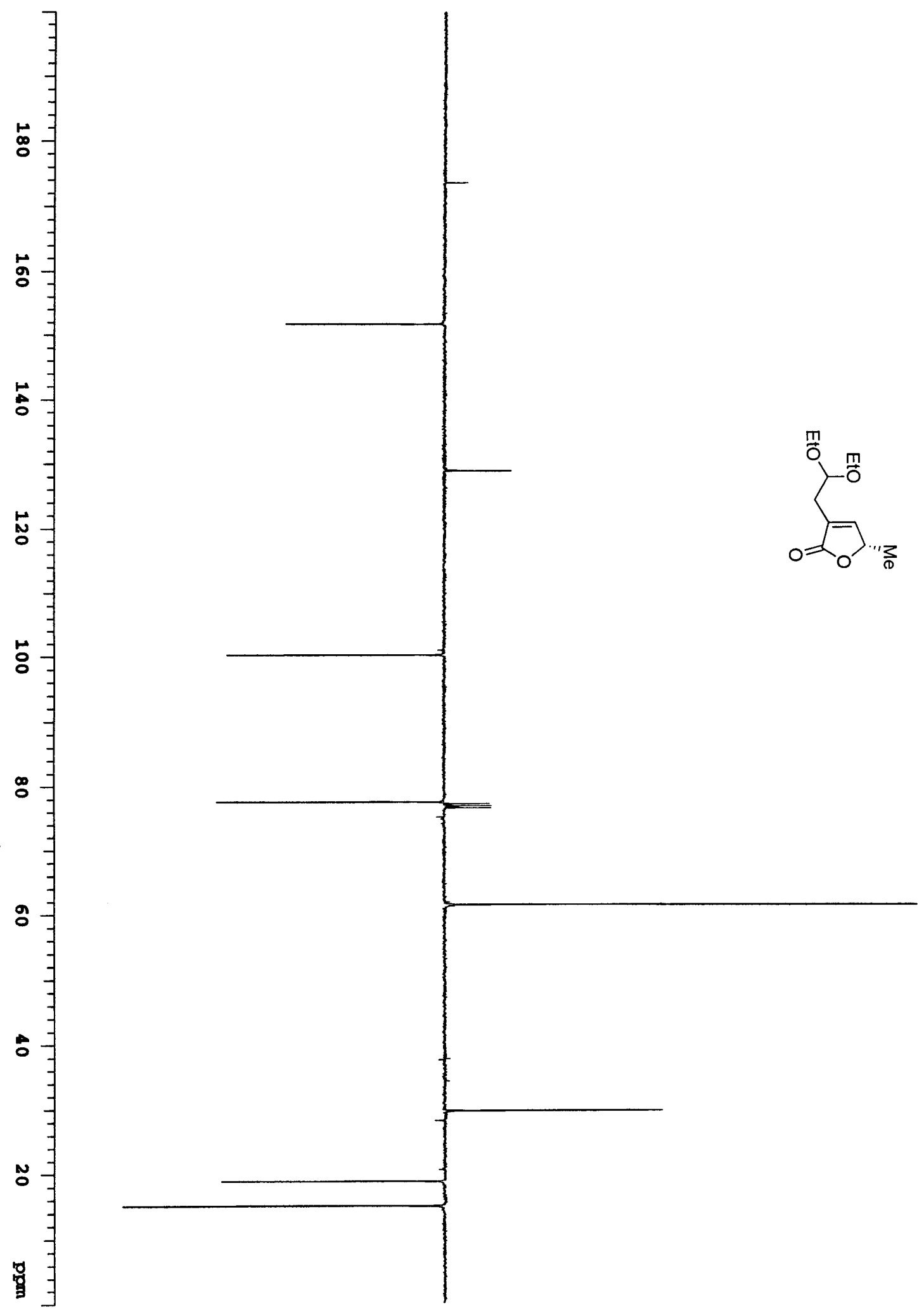




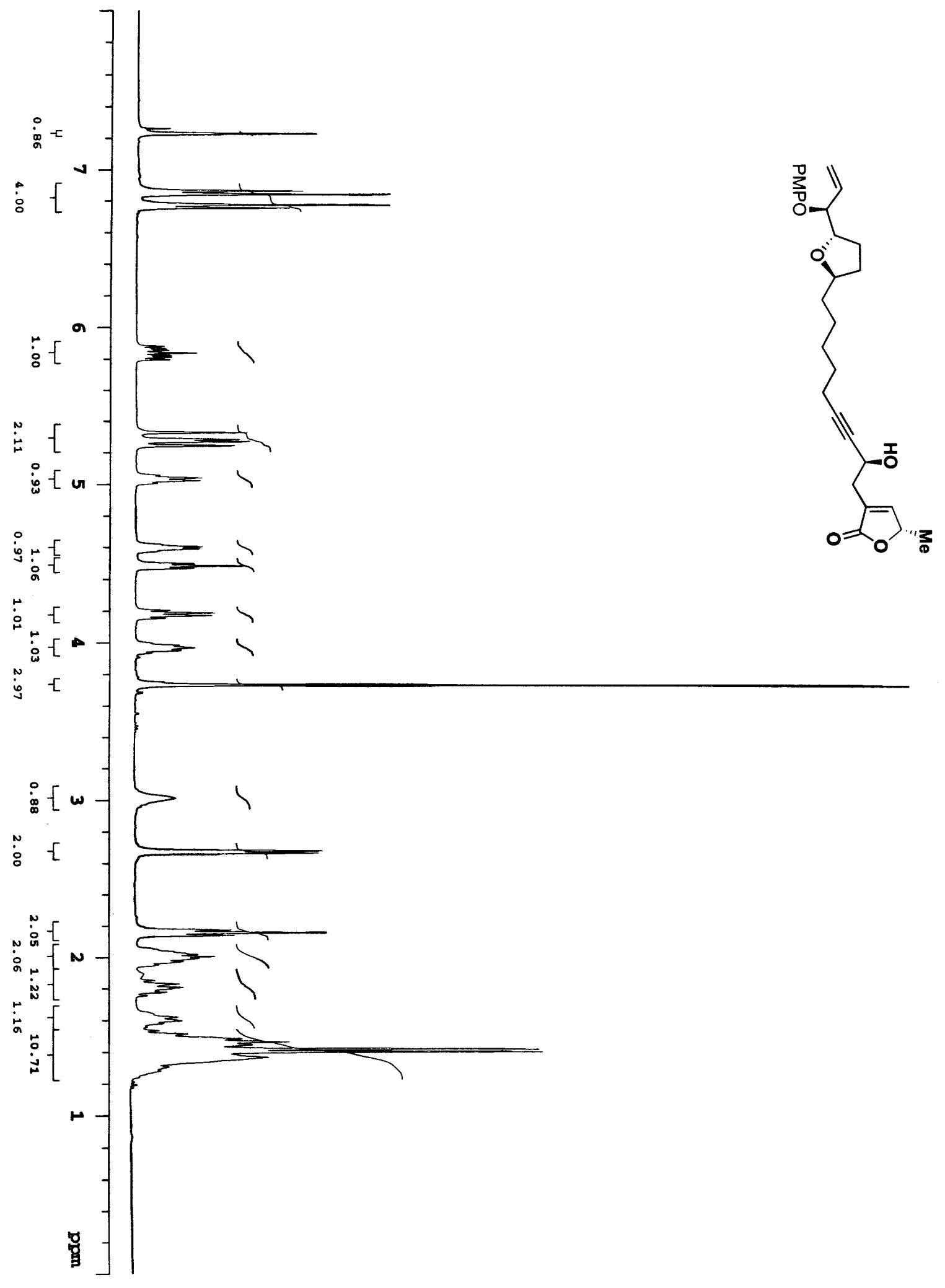



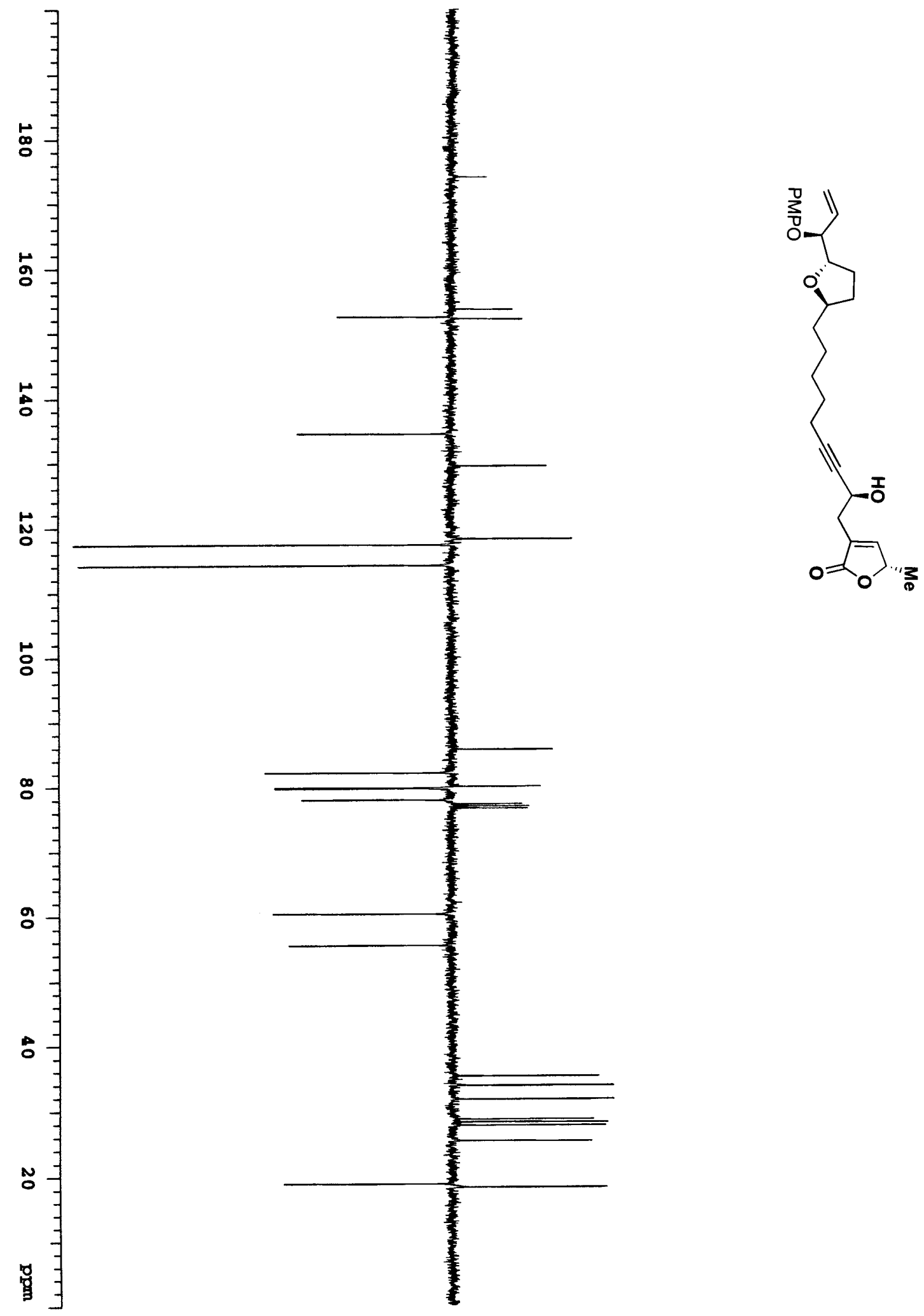


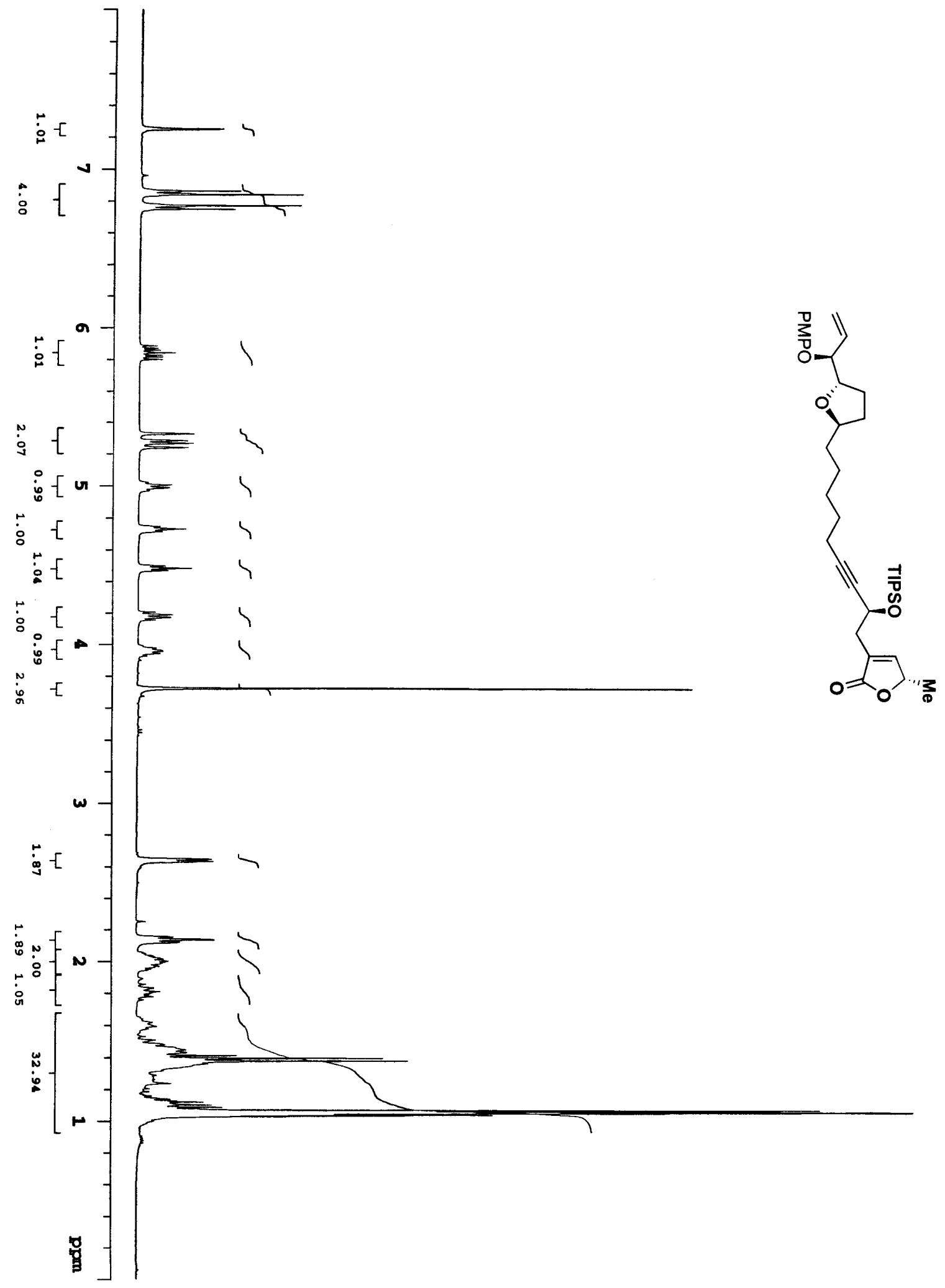



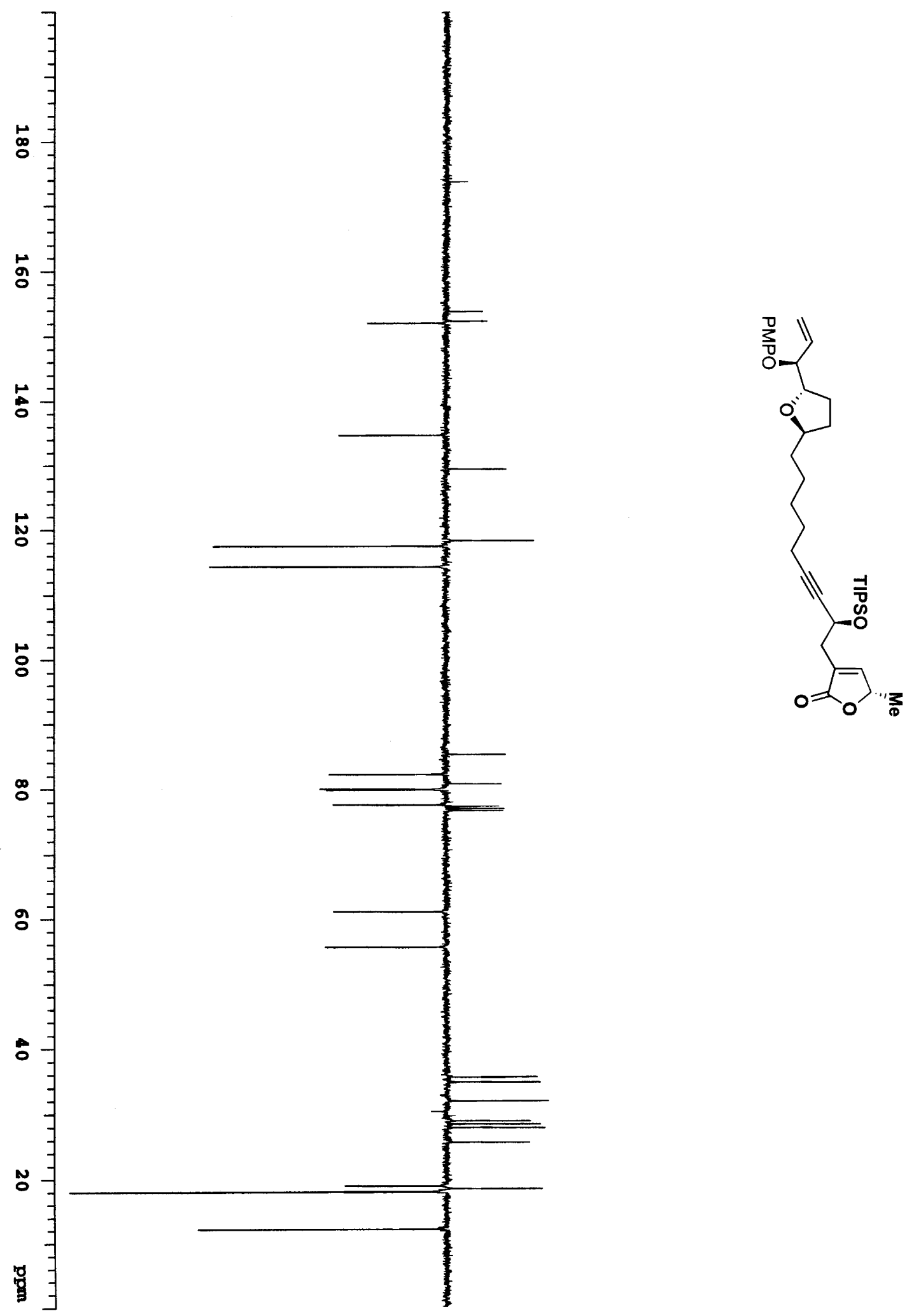


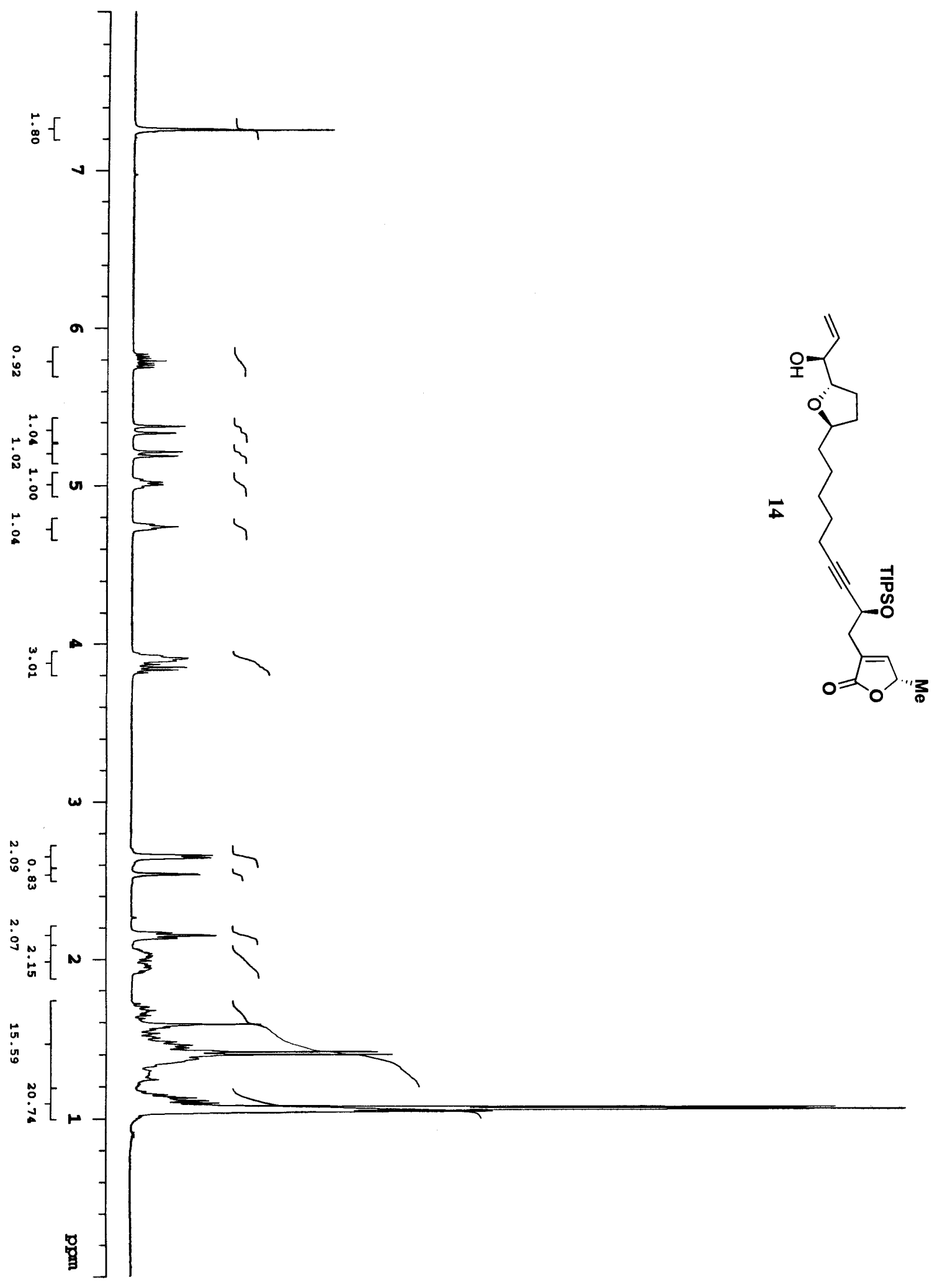



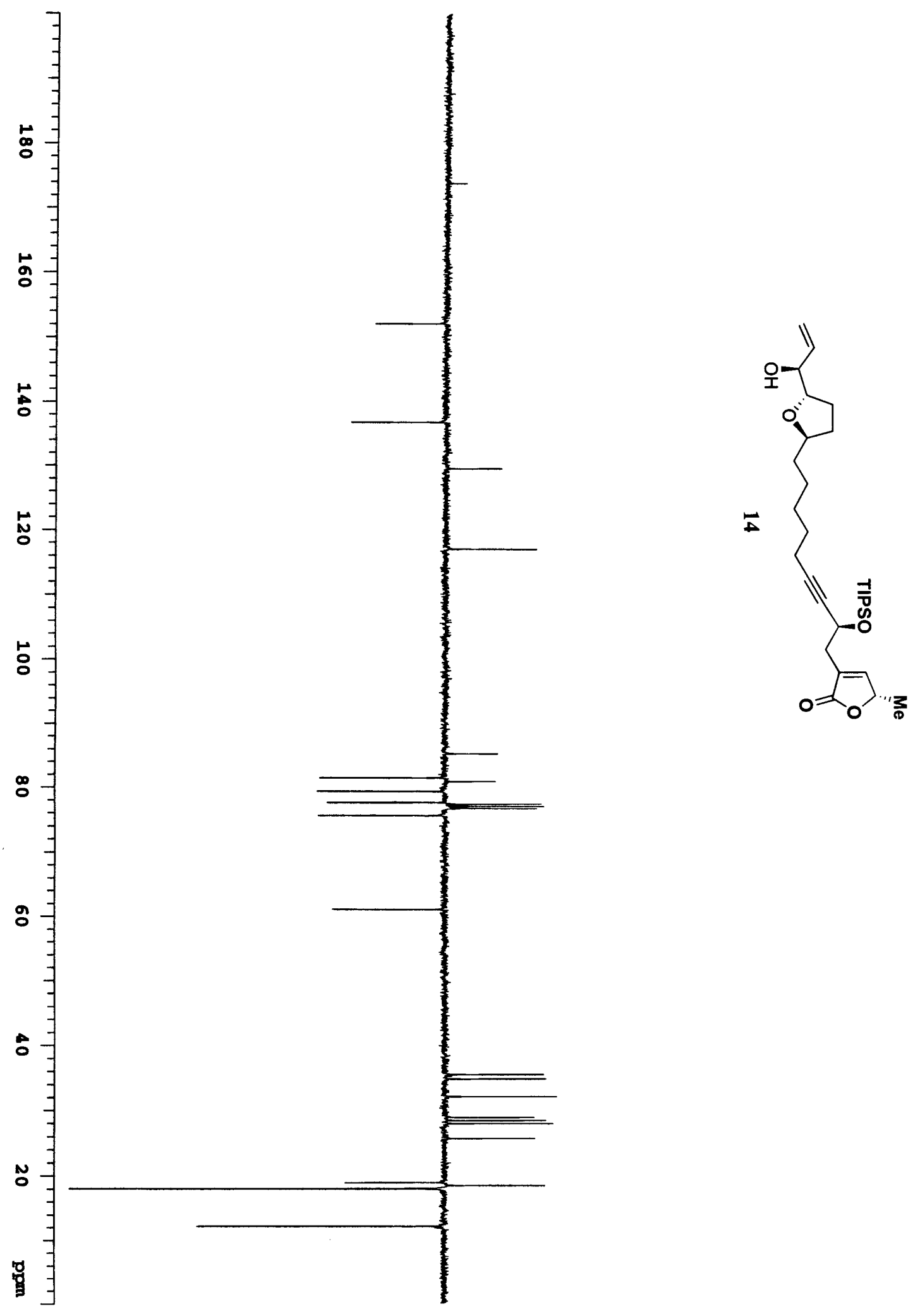


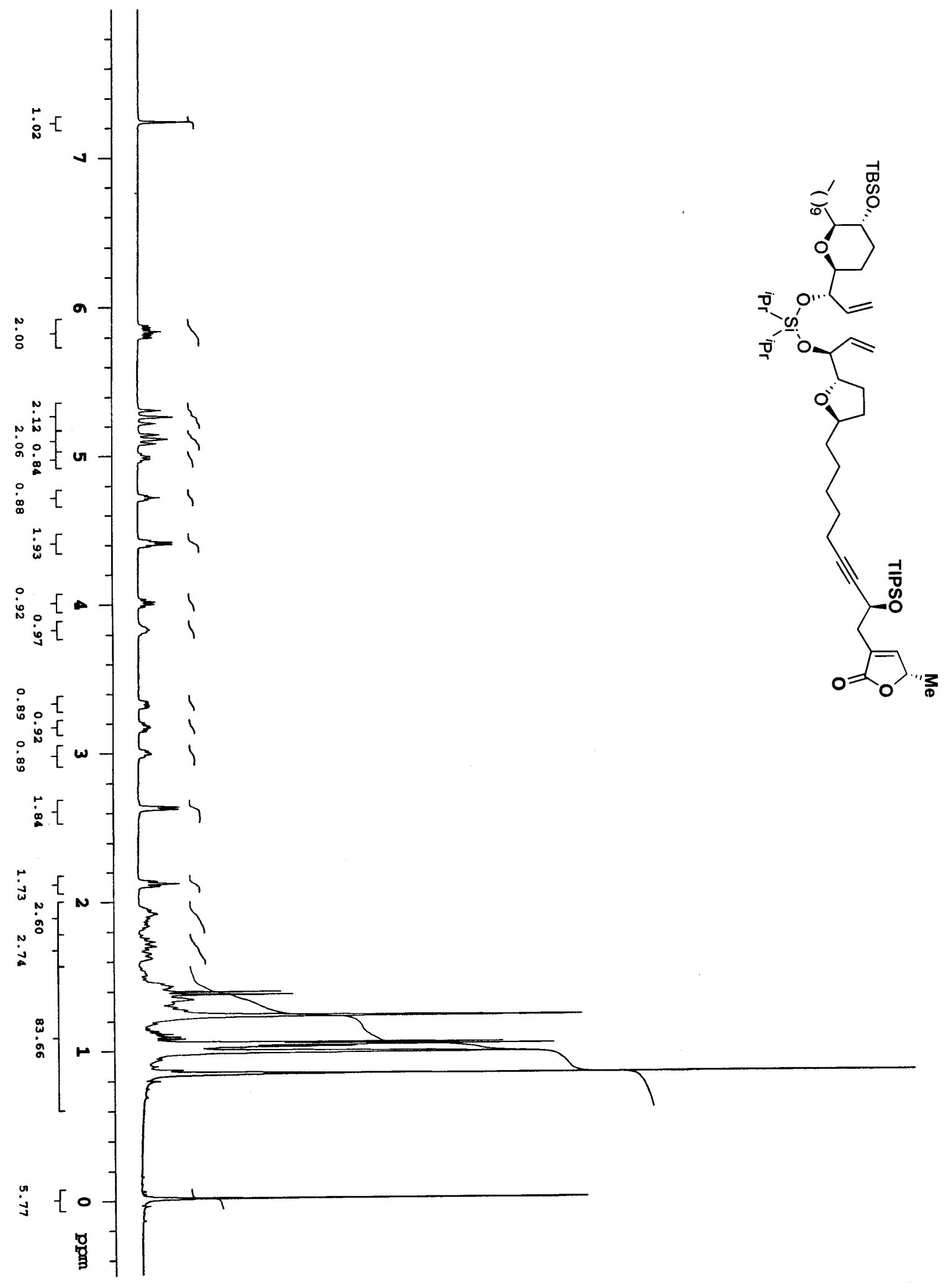



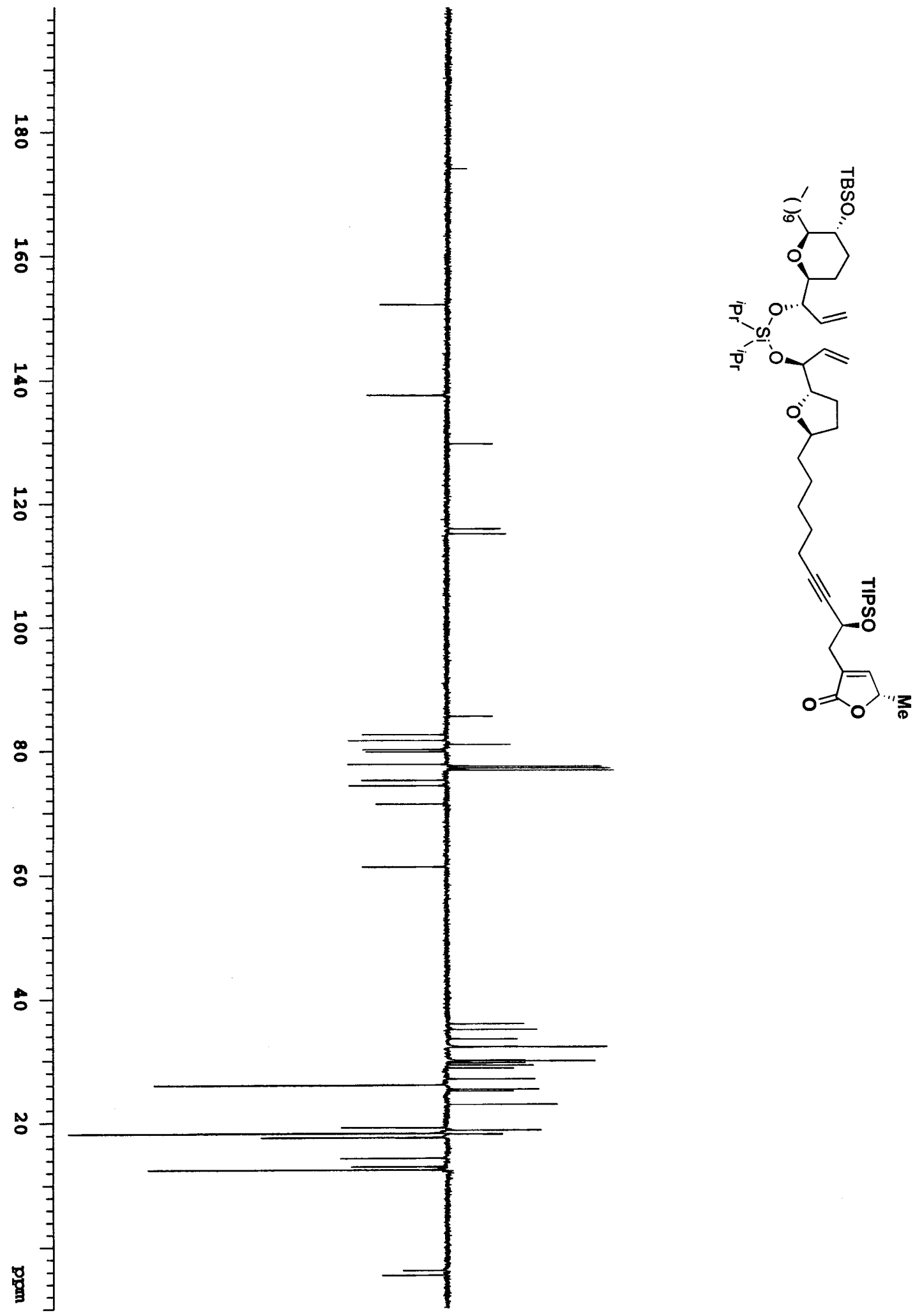


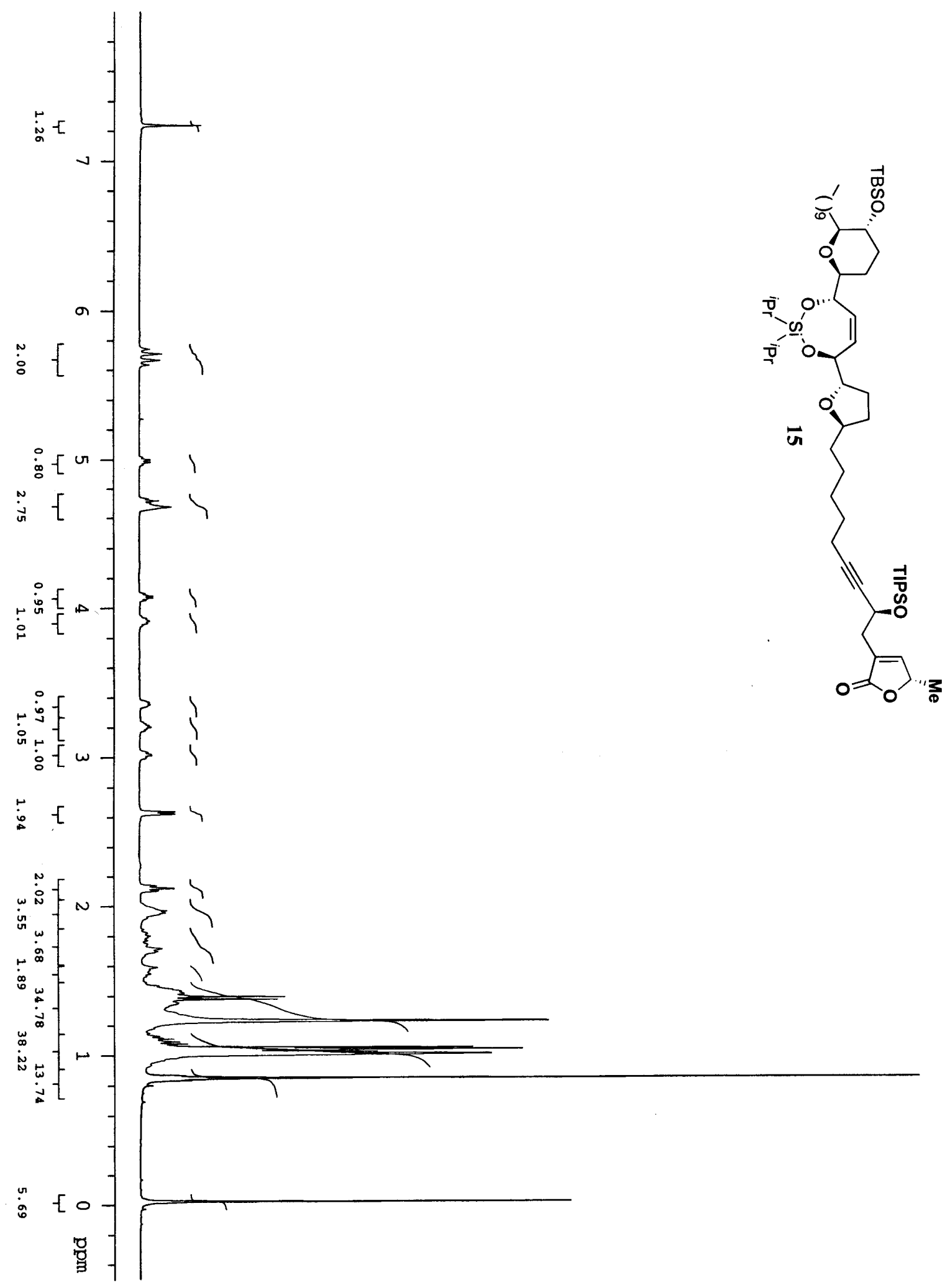




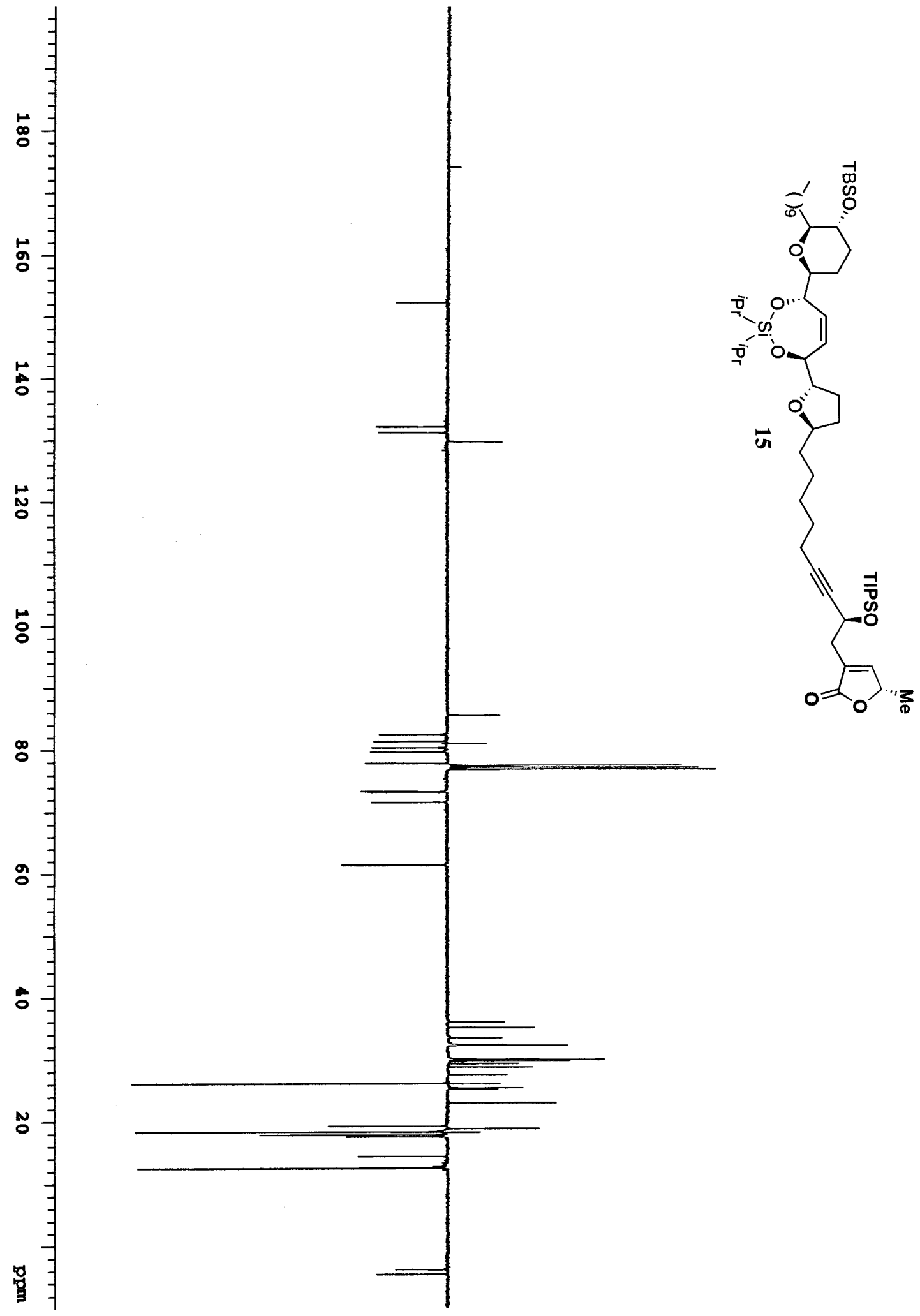




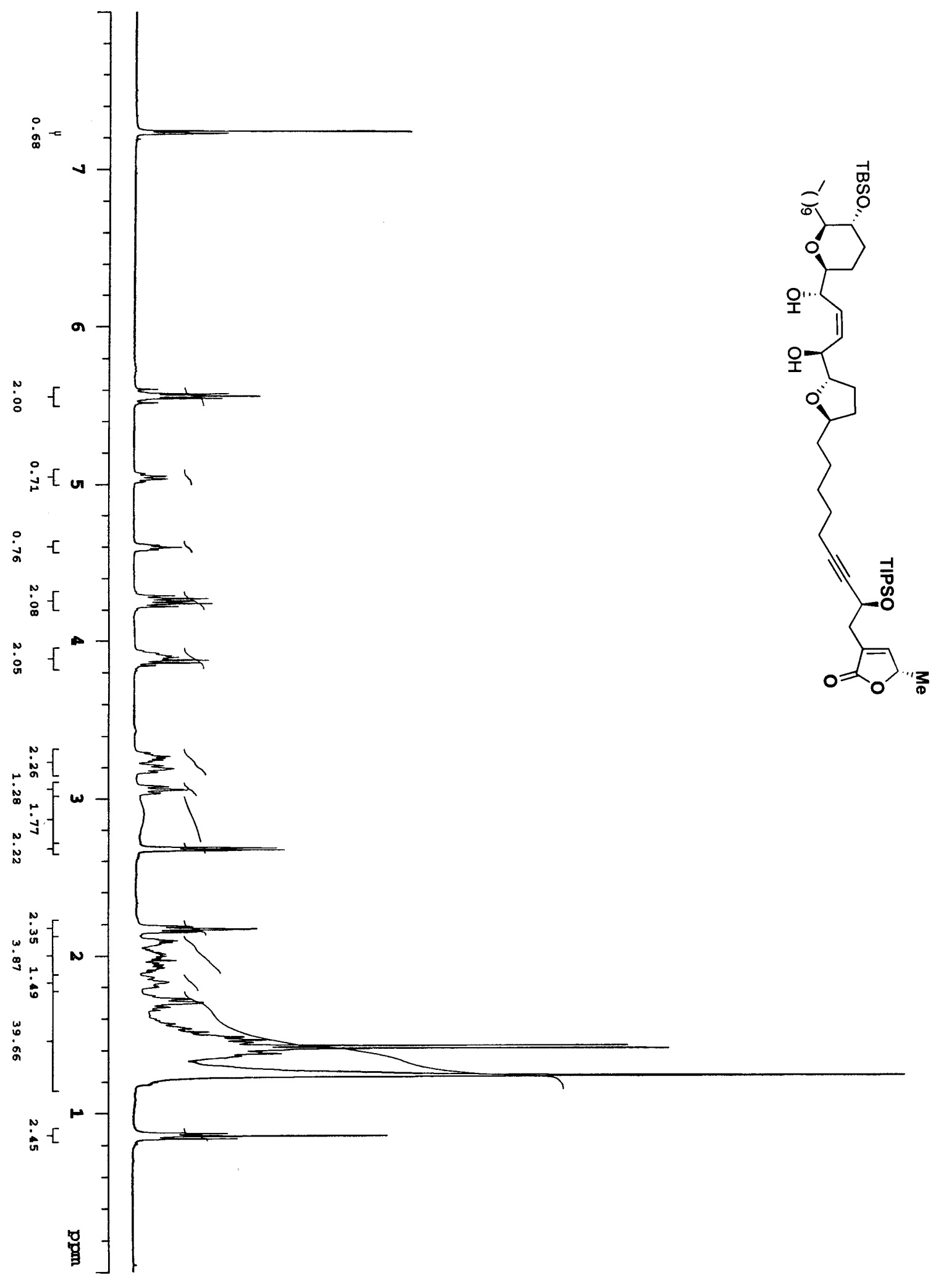



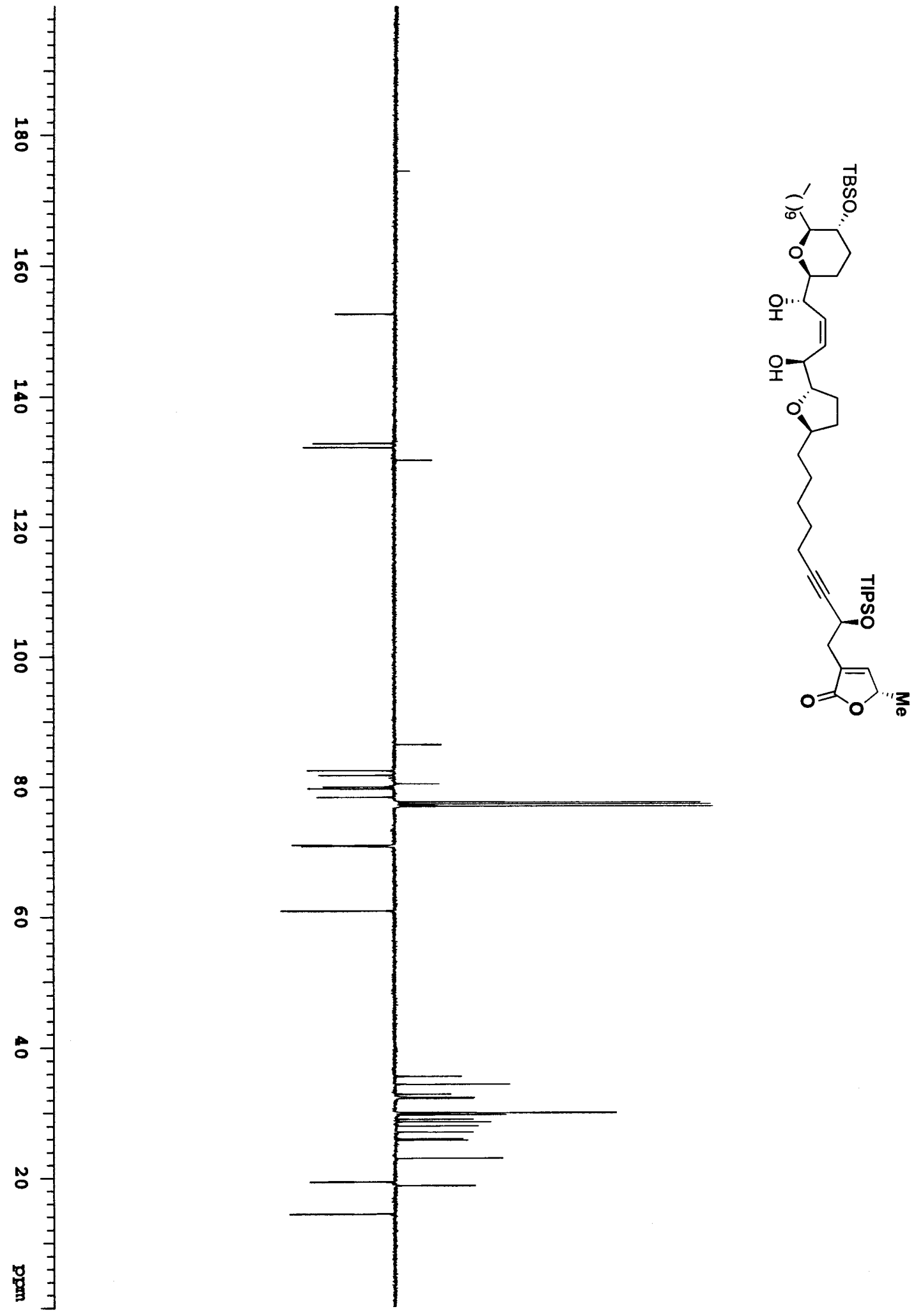


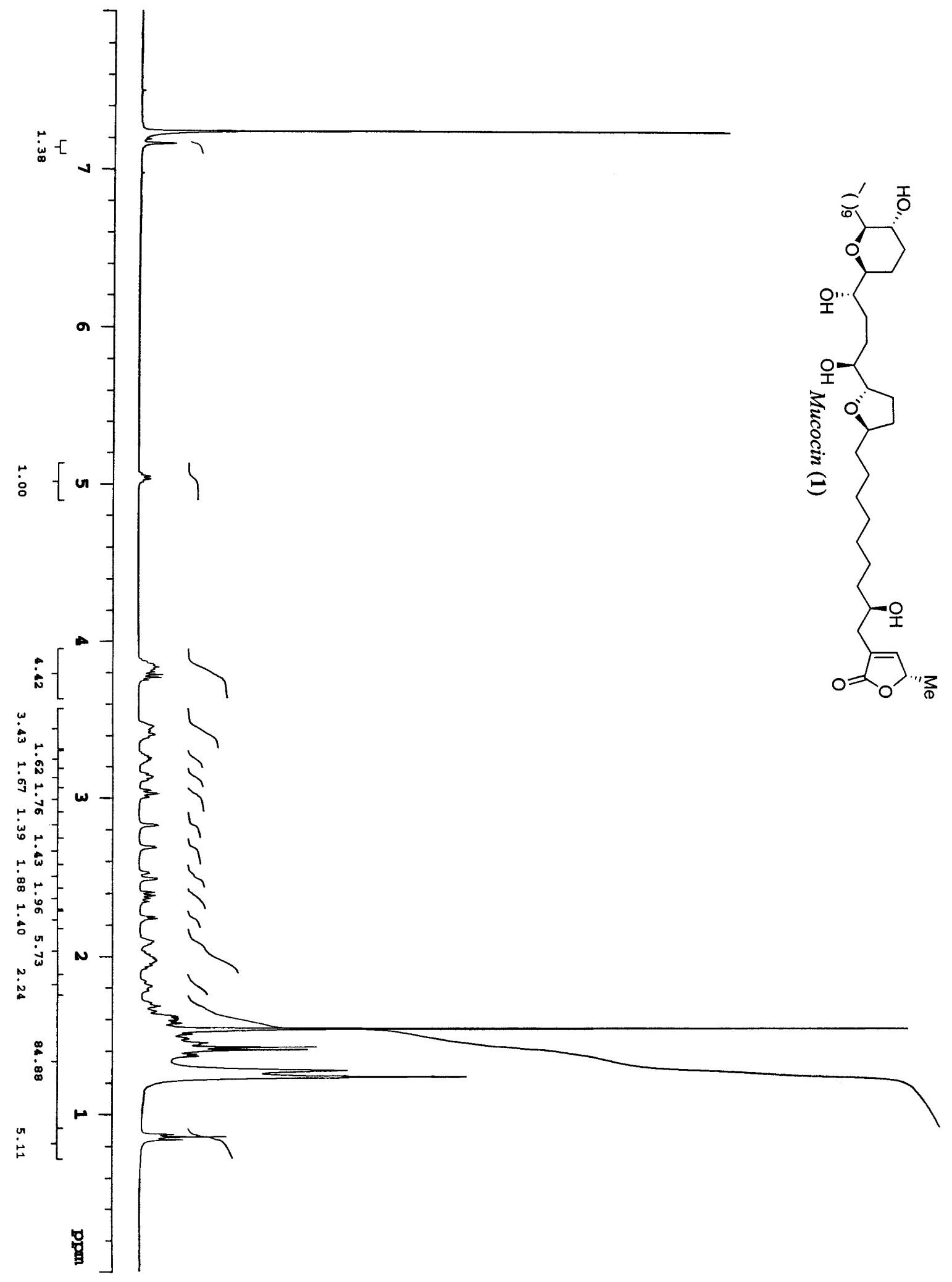




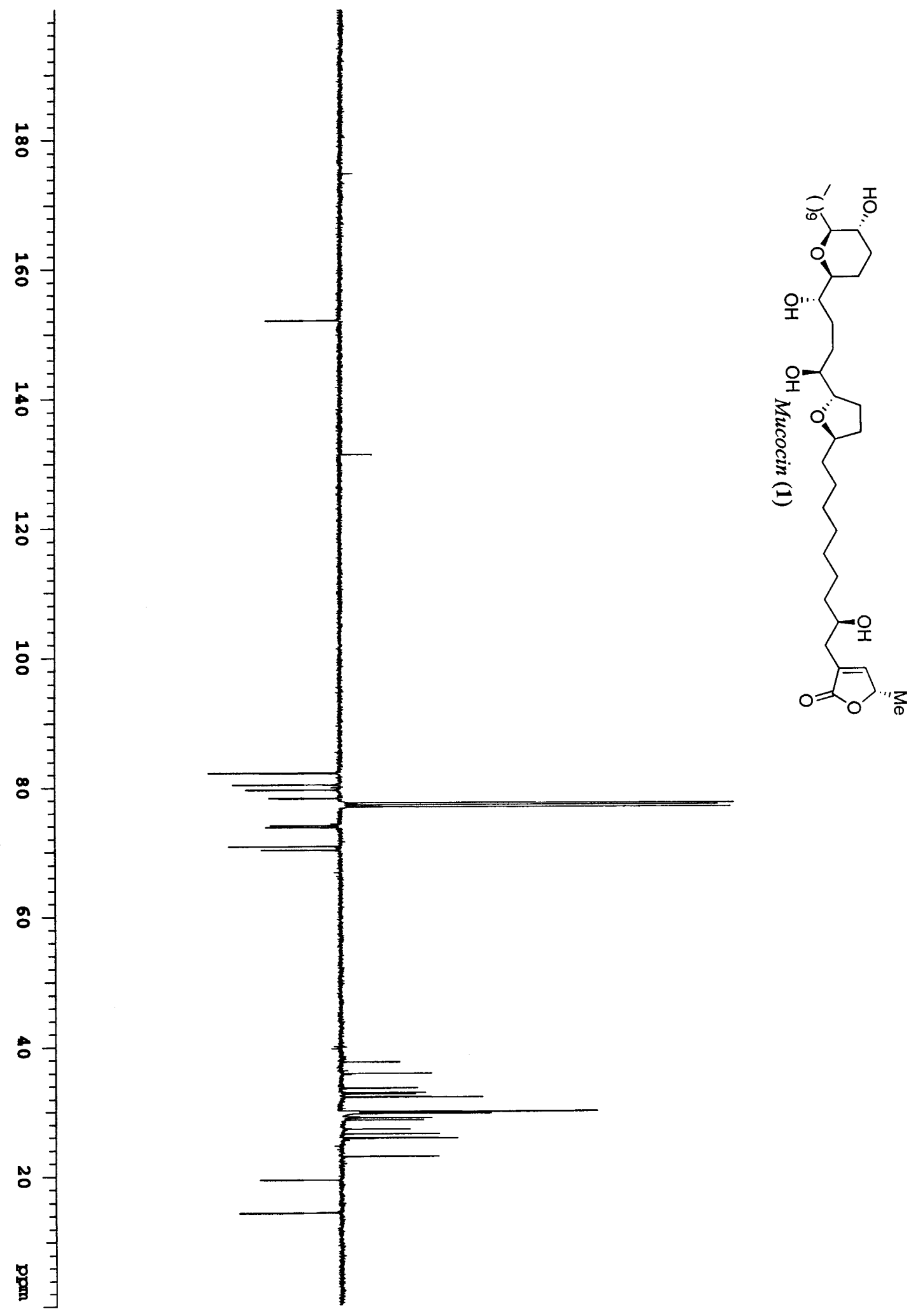

